FiF-avhandling No. 116

Linköping Studies in Social Work and Welfare 2016:2

\title{
Individriktad brottsprevention \\ - om SSPF och viljan att samverka
}

\author{
Christina Söderberg
}

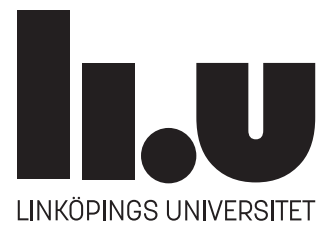

Institutionen för samhälls- och välfärdsstudier Linköpings universitet

Norrköping, 2016 
(C) Christina Söderberg

Omslagsillustration: Janne Johansson

FiF-avhandling No. 116

ISBN: 978-91-7685-798-4

ISSN: $1401-4637$

Tryck: LiU-Tryck, 2016 


\section{Förord}

Om jag visste vad som väntade, skulle jag då ge mig in på denna resa som forskarutbildningen är igen - och vid min ansenliga ålder? Svaret på detta är JA, varje dag i veckan! Visst har vägen varit kantad av såväl berg som dalar så här långt, men jag känner mig oerhört priviligierad som fått denna möjlighet att gå på djupet inom ett område inom socialt arbete som jag brinner för - ungdomar och prevention.

Då jag är kommundoktorand vill jag ge en särskild eloge till Norrköpings kommun och Socialkontoret som ser nyttan med att ha forskare i organisationen. Tack till min chef Kerstin Hellberg och mina arbetskamrater i kommunen som också gjort detta möjligt och stöttat när det varit trögt.

Tack till doktorandkollegor och övriga forskarkollegor på avdelningen för socialt arbete som bidragit med kloka synpunkter, stöd och goda råd i processen. Tack också till alla informanter som bidragit med så mycket tankar och kunskap.

Handledarskapet är avgörande för hur en sådan här process blir och där har jag haft tur! Martin Börjeson och Kerstin Johansson, vilken bra kombination av handledare ni blev, ni kompletterar varandra och har hjälpt mig framåt med stadig hand men även styrt mig tillbaka när jag varit på villovägar.

Till sist men inte minst; min käre make Janne, du har med ditt stöd och dina pep-talks varit den viktigaste personen för mig på resan. Tack till dig och Anna för att ni finns och gör allt så mycket enklare!

I'm something from nothing

You are my fuse (Foo Fighters)

Då ger vi oss på doktorsavhandlingen...

Norrköping den 28 september 2015

Christina Söderberg 


\section{Innehållsförteckning}

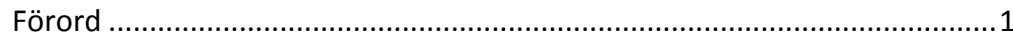

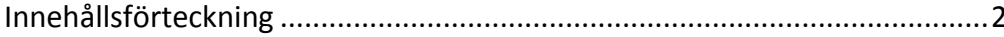

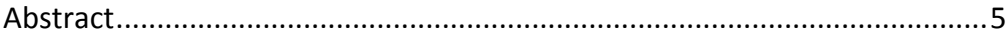

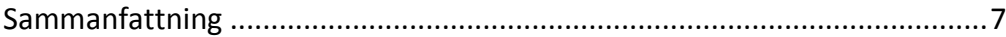

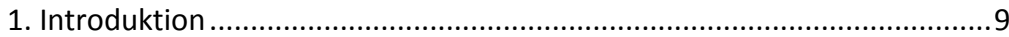

Ett nytt sätt att samarbeta runt unga i riskzon? ......................................11

Brottsprevention på individnivå - exemplet SSPF ...................................12

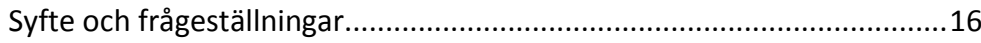

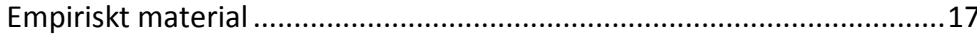

Avgränsningar och centrala begrepp ...................................................18

Förebyggande arbete - prevention.........................................................19

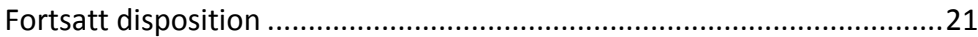

2. Tidigare forskning och forskningsproblemet i sitt sammanhang ............22

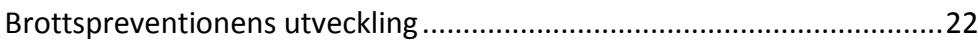

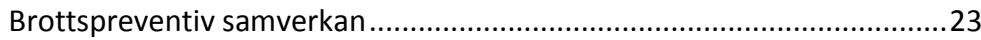

Nyare samverkansformer runt unga individer ........................................24

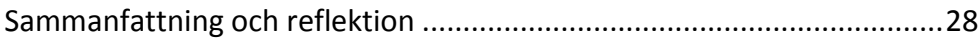

3. Framväxten av individriktad brottsprevention ..........................................31

Den nordiska modellen för brottsprevention ..........................................31

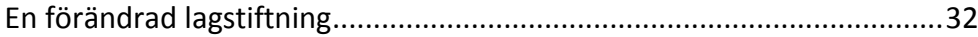

Riktad brottspreventiv samverkan runt unga individer och

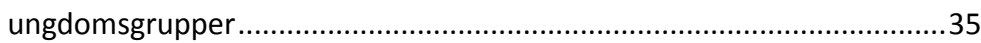

SSPF - samverkansform för snabbare agerande......................................38

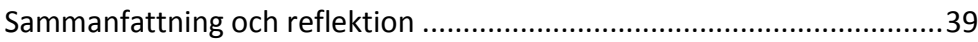

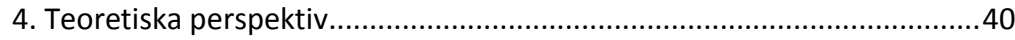

Förändrat samhälle - förändrad brottsprevention ..................................40

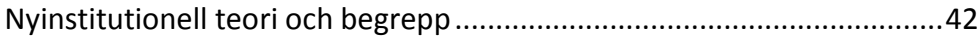

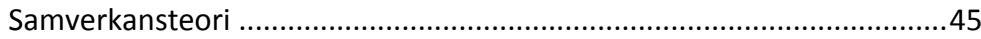


Interaktionen mellan samhällets aktörer och familjen..... .47

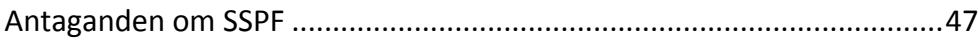

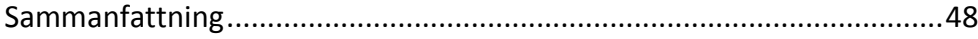

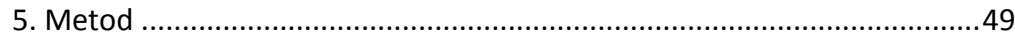

Metodologiska överväganden och begränsningar...................................49

Genomförande av materialinsamling ..................................................52

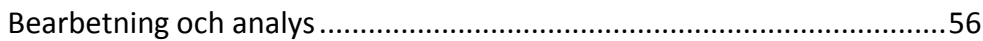

6. Samverkan växer fram .....................................................................61

Idéförpackning på nationell nivå - resan startar ...................................62

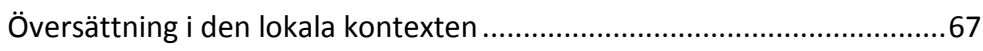

Sammanfattning och reflektion ............................................................

7. Samspelet mellan organisationer och professionella...............................73

Brottspreventivt arbete på individnivå - ett organisatoriskt fält ..............73

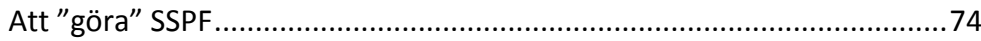

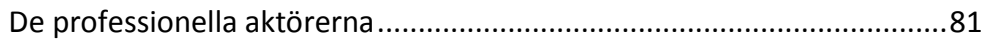

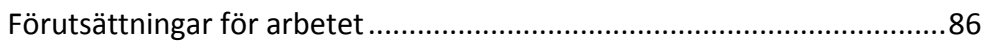

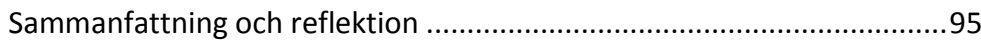

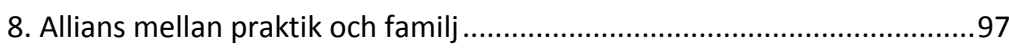

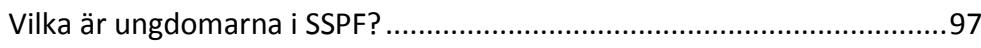

Den gemensamma bilden av den unge .................................................100

Insatser och tänkta resultat i SSPF-arbetet ............................................104

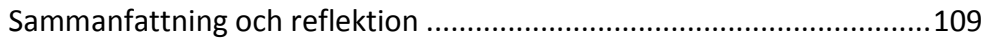

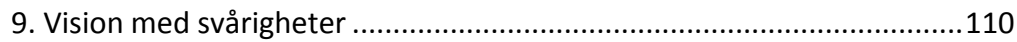

Samhället och brottspreventionen ......................................................111

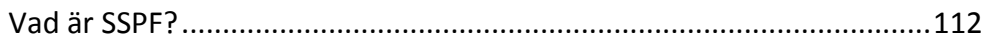

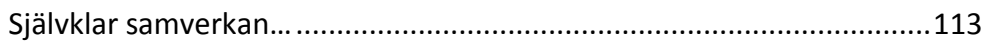

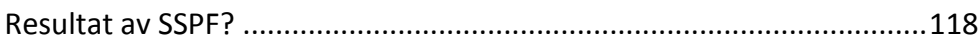

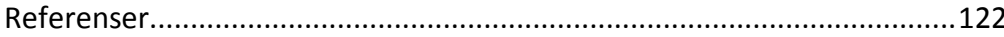




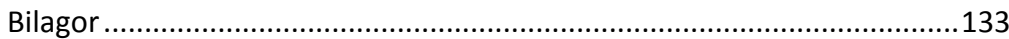

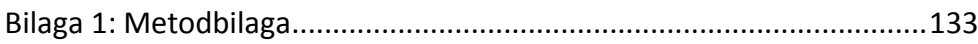

Bilaga 2: Enkät till SSPF-koordinatorer ................................................135

Bilaga 3: Underlag för informerat samtycke .......................................138

Bilaga 4: Frågeområden vid individuella intervjuer SSPF -professionella

140

Bilaga 4: Frågeområden för gruppintervjuer SSPF ..............................141 


\section{Abstract}

This dissertation deals with crime prevention co-operation targeted at the individual level, a relatively new phenomenon in present Sweden and Scandinavia. A certain work model - SSPF, collaboration between school, social services, the police and the leisure sector - is chosen for the study.

The study's purpose is to investigate crime prevention co-operation on individual level as idea and practice. To this end, different focuses are used: policy/structure; organization/profession and practice/family.

The questions the study answers attached to the focus areas above are the following: How has this form of interaction around the young emerged and how is it justified? What are the organizational conditions and how is SSPF experienced by collaborative partners? What does the interaction look like between those representing society's institutions as well as between the professionals and the families?

Three municipalities are examined in the study. The empirical material was collected through studies of documents; interviews, in groups and individually, with collaborative partners in the three municipalities; observations at SSPF-meetings and a survey that were sent to a number of municipalities and districts in Sweden.

On an overall level, the results show that a clear link exists between the general development of society at large and the development of crime prevention work. Generally it can be said that talk of crime prevention today is less focused on structural explanations and action, but rather increasingly concerns control and efficiency, including early discoveries and rapid reaction, which should be strengthened through collaboration at work. The role of the police in individually targeted prevention has become more important and they can be seen clearly as the most dominant party in the SSPF-interaction.

Regarding the current conditions for SSPF-work, the study shows that both the organizational prerequisites (such as stability in organizations), and implementation (such as opportunities for exchange of information at the individual level between the parties) play a major role. The professionals form an alliance in which the common image of the young creates meaning. A tension between support and control becomes visible 
in the work, as well as a kind of uniformity - iso-morphism- whereby the police acting social workers and the social service talk about more control. An alliance is also formed between professionals and parents, aiming mainly at gaining increased control concerning the young person, but also at strengthening support to the parents. The professional's quest for a new way of working to make it better for the target group becomes clear in the study.

In conclusion: this kind of collaborative work within the area of crime prevention is complex, and this study is a contribution to a better understanding of the subject. 


\section{Sammanfattning}

Denna licentiatuppsats behandlar brottspreventiv samverkan på individnivå, vilket är ett relativt nytt fenomen i Sverige och Skandinavien. Ett specifikt arbetssätt, samverkan mellan skola, socialtjänst, polis och fritidssektor - SSPF - undersöks i studien och övergripande studeras hur idén om brottspreventiv samverkan i form av SSPF konstrueras och motiveras, hur den tolkas och omtolkas av samverkansparterna samt hur den omsätts i praktik.

Det mer specifika syftet med studien är att undersöka brottspreventiv samverkan på individnivå som idé och praktik. Tre olika fokus eller aspekter på detta belyses: policy/struktur; organisation/profession och praktik/familj.

De frågeställningar som besvaras i studien och som är kopplade till ovanstående fokusområden är följande: Hur har denna form av samverkan runt unga växt fram och hur motiveras den? Hur ser de organisatoriska förutsättningarna ut och hur upplevs SSPF av samverkansparterna? Slutligen hur interagerar företrädare för samhällets institutioner/ de professionella med familjen?

Tre kommuner ingår i undersökningen. Empiriskt material har samlats in genom dokumentstudie, intervjuer i grupp och enskilt med samverkansparterna i de tre kommunerna, genom observationer vid SSPF-möten samt genom en enkät som gick ut till 30 kommuner och stadsdelar i Sverige.

Resultaten visar att en koppling finns mellan den allmänna samhällsutvecklingen i stort och brottspreventionens utveckling. Allmänt kan sägas att talet om brottsprevention idag handlar allt mindre om strukturella förklaringar och åtgärder. I stället talas alltmer om kontroll och effektivitet, vilket bland annat innebär tidiga upptäckter och snabba insatser. För att lyckas med detta behöver samverkan komma till stånd. Resultaten visar också att polisens roll i individriktad prevention har blivit viktigare och framträder som den tydligaste aktören i SSPFsamverkan.

Gällande förutsättningarna för SSPF-arbetet visar studien att såväl organisatoriska förutsättningar som exempelvis stabilitet $\mathrm{i}$ organisationer och implementeringsmöjligheter, som möjligheter till informationsutbyte på individnivå mellan parterna spelar stor roll för arbetet. De professionella bildar allians där den gemensamma bilden av den unge skapar mening. En spänning mellan stöd och kontroll blir synlig i SSPF- 
arbetet, likväl som en sorts likriktning, där poliser agerar socialarbetare och socialtjänsten talar om mer kontroll. Allians bildas också mellan professionella och föräldrar, vilket främst syftar till ökad kontroll runt den unge, men också till att stärka stödet till den unges föräldrar. De professionellas strävan efter ett nytt sätt att arbeta för att göra det bättre för målgruppen blir trots allt tydligt i studien. 


\section{Introduktion}

Jonathan, 16 år, har gjort vuxna på skolan oroliga, skolpersonalen misstänker att han använder droger och umgås med ungdomar med känd brottslighet och kopplingar till ett kriminellt gäng ${ }^{1}$. Kuratorn på Jonathans skola ser behov av ett möte där vuxna kring Jonathan kan diskutera hans situation samt förslag till åtgärder. I den aktuella kommunen arbetar man sedan en tid med en samverkansform som kallas SSPF - samverkan mellan skola, socialtjänst, polis och fritidssektor. Jonathans fall anmäls till SSPF och snabbt kallas chefer för de fyra samverkansparterna samman för att besluta om parterna ska gå vidare kring Jonathan och i så fall gemensamt planera för åtgärder där varje part ska bidra med sina resurser. Därefter kallas till ett nytt möte, där Jonathan och hans mamma deltar, samt personer från skola, socialtjänst, polis och fritidssektor som kan ha någon relation till Jonathan. Här ska planeras för vilka specifika insatser Jonathan och hans familj kan få, en plan ska göras upp.

SSPF-koordinatorn inleder mötet med att hälsa alla välkomna, gör en sammanfattning av den orosbild som framkommit gällande Jonathan samt betonar att samtycke till informationsutbyte mellan myndigheter inhämtats från Jonathans mamma Elisabeth. Elisabeth nickar instämmande. Koordinatorn redogör också från det SSPFchefsmöte som hållits runt Jonathan där gemensam oro konstaterats och där man vid mötet beslutat att gå vidare. Representanten från polisen berättar att man där känner till Jonathan mycket väl, han har gripits för misstänkt narkotikabruk vid två tillfällen och orosanmälan har skickats till socialtjänsten båda gångerna. Man misstänker främst nätdrogen Spice, men har ännu inte fått svar på de drogtester som gjorts gällande Jonathan. Polismannen framhåller också att man från polisens sida anser att Jonathan umgås i helt fel kretsar och att man är mycket orolig för hans utveckling. Polismannen riktar sig direkt till Jonathan, som

\footnotetext{
${ }^{1}$ Syftet med exemplet är att ge läsaren en inblick i hur ett SSPF- möte kan se ut. I exemplet har ett typfall skapats utifrån olika ungdomar som varit aktuella vid SSPF-möten och de observationer som gjorts vid flera möten. Detta för att minimera risken för identifikation av specifik ungdom.
} 
sitter med huvudet böjt ner mot bordet under första delen av mötet. Modern riktar sig nu till socialsekreteraren och påpekar att hon bett om hjälp för flera månader sedan då hon misstänkte att Jonathan börjat använda droger, men att inget hänt sedan dess. Socialsekreteraren berättar att en utredning gällande Jonathan nu pågår och att han blivit erbjuden att träffa en ungdomscoach, men ännu inte tackat ja. Socialtjänsten inväntar också provsvaren från drogtesterna för att gå vidare med eventuella insatser gällande drogmissbruk.

Skolkuratorn berättar att Jonathan är avstängd från sin gymnasieskola tills skolan försäkrat sig om att han är drogfri, men att han kan erbjudas någon form av hemundervisning. Kurator kommer att hålla kontakt med familjen under tiden Jonathan är avstängd från skolan. SSPF-koordinatorn riktar sig till Jonathan och frågar om han fortfarande är intresserad av motorsport, som han varit tidigare. Jonathan nickar och säger att han mekar med motorer ibland och att han vill börja köra motocross. Elisabeth nickar instämmande och säger att motorer var det enda Jonathan hade i huvudet förr. Koordinatorn riktar sig till socialsekreteraren och uppmanar denna att kolla upp möjligheter för Jonathan att komma igång med någon motorsport samt berättar att det finns en summa pengar avsatt för fritidsaktiviteter i SSPF som kan vara till hjälp här. Koordinatorn säger att en plan över insatser från de olika parterna ska göras upp. Vad kan socialtjänsten göra, finns det andra insatser under utredningen som kan erbjudas- familjebehandling, samtalsbehandling eller krävs placering under en tid? Kan skolan öka sina insatser under avstängningen - extra tid för undervisning, extra stöd? Vem kan stötta Jonathan gällande fritidsaktiviteter, finns någon utanför rummet att kontakta? Den lokala polisens roll blir att hålla koll på Jonathan på stan och meddela socialtjänsten och modern om de träffar på honom i olämpligt sällskap. Dessa frågor diskuteras och olika förslag kommer upp. Koordinatorn frågar Jonathan och Elisabeth om de har några andra önskemål och idéer, Jonathan skakar på huvudet och mamman säger att hon bara önskar att få stöd i att få ordning på Jonathan så det inte fortsätter gå åt fel håll utan att han kan klara skolan. Efter att alla lovat att se över möjliga insatser och återkomma, avslutas mötet och 
koordinatorn lovar att skicka ut den handlingsplan som upprättats till alla samt kalla till ett uppföljande möte inom ramen för SSPF.

Ovanstående exempel ger en inblick i hur ett SSPF-möte kan gå till. Samverkan kring ungdomar i risk för att utveckla kriminalitet och/eller missbruk är inte nytt, men talet om hur samhället nu mer än tidigare kan hjälpa dessa på ett nytt sätt väckte min nyfikenhet på ett särskilt område: samverkan mellan myndigheter runt enskilda barn och unga, där polisens roll blivit alltmer central ${ }^{2}$. Det är just polisen som ofta initierar denna typ av samverkansformer $i$ kommunerna och arbetsformen bygger till stor del på att sekretess mellan myndigheter hanteras genom att samtycke till informationsutbyte inhämtas från vårdnadshavare. En sådan samverkansform är SSPF - samverkan mellan skola, socialtjänst, polis och fritidssektor. SSPF syftar till att unga personer som befinner sig i den så kallade riskzonen för att utveckla kriminalitet och/eller missbruk snabbt ska bli upptäckta och lika snabbt erbjudas insatser från olika håll. Jag har många års praktisk erfarenhet av såväl förebyggande som åtgärdande socialt arbete riktat till ungdomar, i detta arbete har samverkan alltid funnits med som en viktig del. Denna typ av förebyggande samverkansarbete har dock förändrats över tid, vilket har ökat mitt intresse för att fördjupa min kunskap inom området.

\section{Ett nytt sätt att samarbeta runt unga i riskzon?}

Unga i risk för kriminalitet och/eller missbruk är - och har länge varit - i fokus i olika sammanhang $i$ det sociala arbetet. Barn och ungdomar som genom sitt beteende väcker omgivningens oro har blivit föremål för olika typer av interventioner, såväl förebyggande som åtgärdande och såväl på grupp - som individnivå. Skolan har arbetat med sina insatser, socialtjänsten med sina och ibland har polisen fått gripa in. Samarbete mellan dessa myndigheter har förekommit, men oftast på grupp - och områdesnivå, åtminstone då polisen också har deltagit i samverkan. I övrigt har samarbetet till stor del bestått $i$ att polis, skola och

\footnotetext{
2 Det finns ett flertal benämningar på unga som riskerar en negativ utveckling. Jag har valt att genomgående använda benämningen ungdomar/unga i risk för att utveckla kriminalitet och/eller missbruk.
} 
fritidsverksamhet gjort orosanmälningar till socialtjänsten, som sedan tagit över arbetet med den unge, dennes familj och situation.

Under senare år har samverkan i olika former blivit ett allt vanligare sätt att prata om och arbeta med denna typ av ungdomsärenden. En relativt ny särskild typ av samverkan runt dessa ungdomar på individnivå har under 2000-talet vuxit fram, där polisen har en central roll och där parterna öppet mellan myndigheter kan diskutera enskilda ungdomar ${ }^{3}$. SSPF är ett exempel på en sådan samverkansform ${ }^{4}$. En faktor som beskrivs som ett genombrott i denna typ av samverkansarbete är att sekretessen mellan myndigheter - exempelvis polis och socialtjänst tillfälligt kan frångås, vilket görs möjligt genom samtycke till informationsutbyte. Det innebär att samtycke till att bryta sekretessen mellan myndigheterna ges av den enskilde, i detta fall oftast föräldrar till den aktuelle unge. Det sker konkret genom att vårdnadshavaren och $\mathrm{i}$ vissa fall den unge skriver under ett samtyckesdokument.

Utvecklingen av brottspreventiv samverkan runt unga individer som riskerar en negativ utveckling har blivit allt viktigare och ökat i omfattning och det finns ännu begränsat med forskning inom området.

\section{Brottsprevention på individnivå - exemplet SSPF}

SSPF är således en modell eller ett arbetssättför att arbeta brottsförebyggande på områdes-; grupp- eller individnivå med

\footnotetext{
${ }^{3}$ Redan här ska påpekas att samverkan mot ungdomskriminalitet mellan polis och kommun på individnivå omnämns i flera dokument på 1950, 60 och 70-talen och handlar då främst om polisens anmälningsskyldighet till socialtjänst (Edvall Malm 2012). I SSPF och liknande arbetsformer är det nya att man via samtycke till informationsutbyte kan bryta sekretessen. Detta, tillsammans med polisens mer aktiva roll i det som traditionellt ansetts vara socialt arbete är det nya här.

${ }^{4}$ Barnahus och SIG - sociala insatsgrupper är andra exempel på brottspreventiva samverkansmodeller i Sverige. Barnahus kan sägas vara preventivt på så sätt att barnen som brottsoffer får stöd och hjälp vilket ska minska risken för framtida psykosocial ohälsa. Det som främst är gemensamt med SSPF är polisens framträdande roll.
} 
ungdomsproblematik som kriminalitet och drogmissbruk ${ }^{5}$. Det specifika intresset för min studie ligger således i det individriktade arbetet. I SSPFmodellen ska samverkansparterna skola, socialtjänst, polis och fritidssektor med kort varsel kallas samman när någon av dessa parter signalerar oro för en ung person. Detta har föregåtts av bedömningen att den unge på grund av begynnande kriminalitet eller missbruk riskerar att utvecklas ogynnsamt. Därmed finns en uttalad oro som organisationen och dess aktörer vill föra vidare och aktualisera som ett SSPF-ärende. Tack vare detta ska också snabba insatser kunna sättas in.

SSPF har sitt ursprung i Danmark, men har "importerats" till Sverige i ett antal kommuner och anpassats till den nationella och lokala idén om brottspreventiv samverkan. Den danska modellen SSP har mer formen av fältförlagt förebyggande arbete, även om man även där arbetar på individnivå i viss mån (DKR 2008). Det riktade preventiva arbetet har också alltmer influerats av övriga västvärldens brottspreventiva paradigm, exempelvis har Storbritanniens sätt att arbeta med dessa frågor influerat det skandinaviska och svenska konceptet ${ }^{6}$. Detta beskrivs närmare i kapitel 3 .

Nyinstitutionell teoribildning används i uppsatsen för att koppla resultat till policy och struktur. Idén om samverkan i brottspreventivt syfte uttalas på nationell nivå genom olika dokument och färdas sedan till den lokala kontexten, där den översätts och tillämpas efter lokala behov och anpassningar (Czarniawska \& Joerges 1996), vilket medför att olika kommuner tillämpar SSPF på varierande sätt.

\section{Föreställningar om SSPF}

Argyris \& Schön (1977) menar att theory in practice - handlingsteori - kan delas in i anammad teori, det vill säga vad i detta fall SSPF-aktörerna tänker och säger att de gör om de får frågan och bruksteori, det vill säga vad de

\footnotetext{
${ }^{5}$ Omväxlande i texten används begreppen modell och arbetssätt när det gäller SSPF. Begreppet metod är inte relevant för SSPF, vilket kommer att visas längre fram i texten. Benämningen på SSPF diskuteras i slutkapitlet.

${ }^{6}$ Även i Norge finns en liknande samverkansform som är inspirerad av danska SSP. Den norska modellen kallas SLT - samordning av lokale kriminalitetforebyggende tilltak.
} 
verkligen gör och vad som styr de reella handlingarna. Det betyder att antaganden och centrala föreställningar om hur SSPF är tänkt att fungera beskrivs utifrån exempelvis tänkt målgrupp, tänkta insatser och tänkt resultat (Hjelte $\mathrm{m}$ fl. 2010). Utifrån detta blir det möjligt att pröva eller värdera hur den reella interventionen förhåller sig till hur det var tänkt. Hur ser den faktiska målgruppen ut, vilka faktiska insatser har gjorts och vad kan sägas om resultatet? Och framför allt: hur överensstämmer detta med intentionerna för interventionen? Detta är tillämpbart på SSPF.

Nedan görs en enkel beskrivning av antaganden om SSPF som utgår från studiens empiri (dokument och intervjuer). Ambitionen är att tidigt $\mathrm{i}$ texten klargöra något om hur SSPF är tänkt att fungera, vilket ska göra det enklare för läsaren i kommande text.

Tabell 1: Antaganden om SSPF-modellen

\begin{tabular}{|l|l|l|}
\hline Tänkt målgrupp & Tänkta insatser & Tänkta resultat \\
\hline $\begin{array}{l}\text { Unga individer där oro för } \\
\text { begynnande kriminalitet } \\
\text { och /eller missbruk } \\
\text { föreligger och de vanliga } \\
\text { stödsystemen inte räcker } \\
\text { till. }\end{array}$ & $\begin{array}{l}\text { Snabba och intensiva } \\
\text { insatser från var och en av } \\
\text { de samverkande } \\
\text { aktörerna. Insatser och } \\
\text { ansvar görs upp i en } \\
\text { handlingsplan vid SSPF- } \\
\text { möte. }\end{array}$ & $\begin{array}{l}\text { Tack vare samverkansvinster } \\
\text { och snabb aktion från de } \\
\text { olika aktörerna stoppas den } \\
\text { unges destruktiva utveckling } \\
\text { och alternativa } \\
\text { utvecklingsvägar har } \\
\text { erbjudits den unge och } \\
\text { familjen. }\end{array}$ \\
\hline
\end{tabular}

Här används beskrivningen för att förtydliga intentionerna med SSPFmodellen. För att förstå samverkansformen SSPF är det intressant att senare återkoppla till de antaganden som beskrivs ovan utifrån de tre kommuner som jag studerat och deras specifika SSPF-arbete. I kapitel 9 återkopplas till denna beskrivning för att relatera dessa antaganden med studiens resultat, det vill säga den anammande teorin med bruksteorin (Argyris \& Schön 1977).

De individer som är i fokus är alltså unga i risk för att utveckla kriminalitet och/eller missbruk. Nedan beskrivs målgruppen utförligare.

\section{Ungdomarna - målgruppen för SSPF}

Utifrån den lokala tillämpningen av modellen varierar målgruppen för SSPF mellan kommunerna, men generellt gäller att de unga individer 
som blir föremål för insatser i form av SSPF-samverkan på något sätt har väckt oro i sin omgivning - hos familj, skola, polis eller fritid ${ }^{7}$. Den unge befinner sig i risk för att utvecklas negativt och har på något sätt redan debuterat i någon form av normbrytande beteende. Det kan handla om misstanke om experimenterande med droger, begynnande kriminalitet eller kontakter med kriminella nätverk.

Åldersspannet för benämningen av ungdomar - eller unga - varierar. Målgruppen åldersmässigt för det brottspreventiva arbetet $\mathrm{i}$ denna specifika studie är unga personer i åldersspannet 10-25 år, även om det vanligaste spannet är mellan 12-18 år.

Ett skäl till aktualisering för SSPF kan vara misstanke om att den unge använder narkotika. När det gäller missbruk av narkotika bland unga räknar man med att cirka 3-4 procent av ungdomar i högstadie- och gymnasieåldern använder narkotika mer regelbundet. Årligen återkommande drogvaneundersökningar som genomförs av Centralförbundet för Alkohol- och Narkotikaupplysning - visar också att runt 17 procent av ungdomar i gymnasieåldern någon gång provat narkotika. Långt ifrån alla som provar narkotika fortsätter att använda det. Den vanligaste drogen bland unga vid sidan av alkohol är cannabis. På senare år har användningen av så kallade nätdroger blivit mer vanliga såväl bland ungdomar som bland mer etablerade missbrukare ${ }^{8}$ (Källa: CAN:s drogvaneundersökning bland skolelever; can.se).

Ett annat skäl för att en ungdom aktualiseras för SSPF kan vara att det finns oro för begynnande kriminalitet. Brottslighet i form av enstaka brott är relativt vanligt bland tonårsungdomar (Estrada \& Granath 2008, Andershed \& Andershed 2010). Överlag är brottslighet bland unga klart mer vanligt förekommande än bland barn under 12 år och vuxna och runt fem procent av de brottsaktiva ungdomarna fortsätter att begå brott

\footnotetext{
7 Begreppet "väcka oro" är oprecist, men används ofta i sammanhang där exempelvis orosanmälan till socialtjänsten görs. Orsaker till den väckta oron kan vara många, därför är det ett begrepp som är användbart här.

8 Nätdroger är sinnesförändrande preparat som säljs över internet. Myndigheterna har svårigheter att hinna med narkotikaklassning av dessa, varför många av preparaten är lagliga. Men även redan narkotikaklassade preparat säljs över nätet. De senaste åren har användningen och försäljningen av nätdroger ökat kraftigt (can.se).
} 
i vuxen ålder. Unga i åldern 15- 20 år är den grupp som är mest brottsaktiv, för de flesta avtar de kriminella aktiviteterna i 20 -årsåldern. Forskning tyder på att en stor del av de mest brottsaktiva som dessutom fortsätter sin brottsliga bana efter 20 års ålder debuterar med kriminella handlingar före 12 års ålder (Andershed \& Andershed 2010). Med denna bakgrund menar flera forskare att tidiga upptäckter genom kartläggning av riskfaktorer för kriminalitet gör det möjligt för tidiga interventioner i familj och för barn/ungdom (se bland annat Anderhed \& Andershed 2010, Lab 2004). Detta så kallade riskparadigm är starkt i dagens brottsprevention - i såväl forskning som praktik, men möter också motstånd hos andra forskare. Vissa menar till exempel att risk för tidig stämpling föreligger genom allt tidigare identifikation av dessa riskfaktorer (Kelly 2012). Detta beskrivs närmare i kapitel 2 och 3.

På senare år har den organiserade kriminaliteten ökat i omfattning $\mathrm{i}$ såväl Sverige som i närliggande länder och tendensen att unga söker sig, eller rekryteras, till dessa gäng, är mer tydlig idag än tidigare (SOU 2010:15). Ambitionen att motverka rekrytering till kriminella nätverk ligger idag till grund för mycket av den individriktade brottspreventionen i Sverige, vilket SSPF är ett exempel på.

\section{Syfte och frågeställningar}

Övergripande undersöks hur brottspreventiv samverkan på individnivå konstrueras och motiveras, hur företrädare för olika institutioner tolkar och omtolkar SSPF i interaktion med varandra, samt hur detta omsätts i praktiken.

Det mer specifika syftet med licentiatuppsatsen är att beskriva och analysera brottspreventiv samverkan på individnivå som idé och praktik, med arbetsformen SSPF som exempel.

Studiens frågeställningar är:

- Hur har denna form av samverkan runt unga individer vuxit fram och hur motiveras den?

- Hur ser de organisatoriska förutsättningarna ut och hur upplevs SSPF av samverkansparterna?

- Hur interagerar företrädare för samhällets institutioner/ de professionella med familjen? 
För att besvara dessa frågor behöver olika nivåer eller aspekter studeras. Tre fokusområden har identifierats för studien: en övergripande samhällsnivå som handlar om policy och struktur, en organisatorisk nivå som också fokuserar på profession samt en nivå som fokuserar på samspelet mellan den brottspreventiva praktiken och familjen.

Figur 1: Den brottspreventiva modellen SSPF är möjlig att studera med flera fokus:

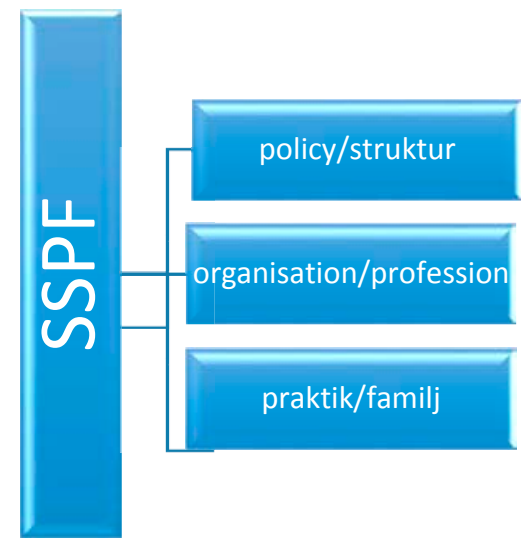

\section{Empiriskt material}

För att studera SSPF enligt ovan har en varierad empiri samlats in. Tre undersökningskommuner som är i olika stadier av sitt SSPF-arbete har valts ut till studien. De dokument som ligger till grund för och styr SSPF från nationell till lokal nivå har analyserats, jag har intervjuat samverkansparter- de personer som ingår i SSPF-grupperna från de olika organisationerna- såväl i grupp som enskilt. Därutöver finns empiri i form av observationer vid SSPF- möten samt en enkät till flera SSPFkommuner. Mångfalden av empiriskt material bidrar till en innehållsrik bild av hur SSPF formats och tillämpas i de tre kommunerna. 


\section{Avgränsningar och centrala begrepp}

Utöver de fokusområden som beskrivits, är fokus på individ, det vill säga i detta fall den unge enskilde, ett viktigt fokusområde. Detta ryms dock inte inom ramen för denna uppsats. Dessutom blev det tidigt i studien tydligt hur viktiga de övriga fokusområdena var för att förstå SSPF, varför jag har valt att lyfta fram dessa.

Denna studie avgränsas således till brottsprevention riktad mot unga individer som är identifierade att befinna sig i risk för kriminalitet och/eller missbruk. För att avgränsa ytterligare så handlar studien om ovanstående interventioner på individnivå och inte på gruppnivå även om det också förekommer inom modellen SSPF. Forskningsområdet är avgränsat till brottspreventiv samverkan på individnivå, men vart och ett av de begrepp som bildar forskningsområdet behöver definieras närmare.

Nedan definieras begreppen samverkan, prevention och brottsprevention och sist brottspreventiv samverkan för att ringa in det specifika för studien.

\section{Samverkan}

Denna uppsats behandlar brottspreventiv samverkan runt unga individer i utsatta livssituationer där risk för utveckling av missbruk och/eller kriminalitet föreligger. Specifikt fokus ligger på individriktad brottsprevention i form av SSPF-modellen. Dessa unga personer är som sagt i fokus i många sammanhang, inte minst när kommuner diskuterar sitt brottsförebyggande arbete. Socialtjänstens ansvar för förebyggande arbete, särskilt gällande risk för missbruk eller unga som riskerar att utvecklas ogynnsamt, finns beskrivet i socialtjänstlagen (SFS 2001:453 SoL) och här beskrivs socialtjänstens ansvar för en fungerande samverkan med andra myndigheter.

Mycket av samarbetet mellan myndigheter benämns samverkan, utan att begreppet problematiseras. Det finns flera teoretiska modeller för att förklara och beskriva samverkan och hur komplext detta kan vara (se t ex Boklund (2005); Axelssson \& Bihari Axelsson (2007); Horwath \& Morrison (2007); Danermark (1999, 2004). I studien används Horwath och Morrisons modell, vilken innebär att strävandet efter samverkan kan 
ta sig uttryck på olika nivåer där kommunikation är den lägsta nivån av samverkan och integration den högsta (Horwath \& Morrison 2007).

Förebyggande arbete - prevention

Förebyggande arbete, eller prevention som är ett mer vanligt förekommande begrepp idag, kommer från latinets praeve nio - att komma före. Syftet med preventivt arbete kan vara såväl att motverka en negativ utveckling som att arbeta för en positiv utveckling (Sahlin $2000 \mathrm{~s}$. 45). Prevention brukar delas in i tre nivåer - generell eller primär, selektiv eller sekundär och indikerad eller tertiär (Lab 2004, Sahlin 2000, FerrerWreder $\mathrm{m}$ fl. 2005). Inom folkhälsoarbete och även i annat preventivt och socialt arbete används numera begreppen generell, selektiv och indikerad prevention mer frekvent än primär, sekundär och tertiär prevention och är också de begrepp som används i denna uppsats. Med indelningen menas att generell prevention är allmän och riktas till befolkningen i stort, det kan vara insatser i skolan riktade till alla elever eller föräldrar och så vidare.

Den selektiva preventionsnivån är mer riktad till identifierade riskgrupper eller individer, exempelvis föräldrastödsprogram där identifierade familjeproblem föreligger eller gruppverksamhet för unga med utåtagerande beteende. Insatser riktas ofta mot unga som betecknas vara i den så kallade riskzonen för olika typer av destruktivt leverne. Den indikerade preventionsnivån har mer karaktären av behandlande eller förändrande insatser. Det ligger oftare på individnivå och används då problembilden är tydliggjord.

\section{Brottsprevention}

När det handlar specifikt om brottsprevention är även en annan indelning vanlig - situationell och social brottsprevention, där den förra handlar om att minska tillfällen till brott medan den senare handlar om att minska brottsbenägenheten hos den enskilde (Sahlin 2000, Sarnecki 2004).

För att ytterligare förtydliga och avgränsa, så behandlas således i denna studie social brottsprevention - samhället vill påverka unga personer till minskad brottsbenägenhet. Det handlar också om riktad brottsprevention på selektiv och indikerad nivå, vilket sammanfattas i 
uppsatsen som riktad prevention. Den riktade brottspreventionen $\mathrm{i}$ studien har dessutom individfokus.

Begreppet brottsprevention definieras på olika sätt i olika studier och/eller program. En anledning till att det är svårt att fastställa någon entydig definition är att såväl brottsbegreppet som preventionsbegreppet kan ha flera tolkningar och innebörder beroende på ideologi, historia och kulturella förhållanden (Sahlin 2000, Wahlgren 2014). Den definition som ofta används i den anglo-saxiska- och även i svensk kriminologilitteratur är Steven P. Labs (2004: 23):

crime prevention entails any action designed to reduce the actual level of crime and/or the perceived fear of crime

Brottspreventiv samverkan

På senare år har alltfler initiativ till samverkan runt ungdomar i utsatthet kommit från polisens håll, bland annat till den samverkansmodell som är fallet i denna studie. Specifikt för denna nyare typ av samverkan är att den sker runt individer, att sekretessen hanteras genom samtycke och att polisens roll är central och viktig, även på individnivå.

En definition som den av brottsprevention ovan är ganska allmänt hållen och i Sverige har Brottsförebyggande rådet med flera utifrån etablerade definitioner av samverkan och brottsprevention, valt att precisera definitionen av brottspreventiv samverkan, eftersom denna form av brottspreventivt arbete är mer och mer vanlig och aktuell. En etablerad definition av samverkan (Boklund 2005) slogs samman med en vanligt använd definition av brottsprevention (se Lab ovan samt Sarnecki 2004):

Samverkan i brottsförebyggande arbete innebär att parterna tillför sina specifika resurser, kompetenser och kunskaper för att man gemensamt ska minska sannolikheten för brott och reducera skadeverkningar (inklusive rädsla) av brott (Brå $m$ fl. 2010:11).

Forskningen om denna specifika typ av brottspreventiv samverkan är ännu sparsam i Sverige, varför denna studie kommer att vara ett bidrag till kunskapsområdet. 


\section{Fortsatt disposition}

Uppsatsens disposition utgår från syfte och frågeställningar samt figuren på sidan 12, där tre möjliga fokusområden för studien beskrivs; policy/struktur, organisation/profession och praktik/familj. Kapitlen börjar i ett vidare perspektiv och fokuserar därefter mot övriga fokusområden. Resultatkapitlen är upplagda så att kapitel 6 kopplas till policy/struktur, kapitel 7 mot organisation/profession och kapitel 8 mot praktik/familj.

I kapitel 2 fokuseras på detta sätt tidigare forskning inom fältet och denna studies relevans skrivs in. I kapitel 3 beskrivs framväxten av brottspreventiv samverkan på individnivå. Utgångspunkten är beskrivningen av brottsprevention i Norden från år 2000 - the Nordic model of crime prevention - och därifrån lyfts förändringar i lagstiftning och andra samhälleliga förutsättningar för brottsprevention fram. Därefter övergår fokus till det lokala brottspreventiva arbetet och specifikt det som utförs på individnivå, såsom SSPF. Kapitlet kan ses dels som en bakgrund till forskningsområdet, men också som resultat då viss analys sker redan här.

Det teoretiska resonemanget eller ramverket beskrivs i kapitel 4 och utgörs av de teoribildningar och begrepp på samhällsnivå samt organisations/professionsnivå som används i studien som stöd för analys och tolkning av materialet. Kapitlet följer den tidigare beskrivna strukturen. Kapitel 5 ägnas åt beskrivning av metod - den empiriska resan till resultat där tillvägagångssättet för just denna studie beskrivs, liksom analys- och tolkningsförfarande. De tre följande kapitlen är resultatredovisning och analys kapitel 6 fokuserar på de dokument som vägleder och styr en samverkansmodell som SSPF och motiverar framväxten av individriktad brottsprevention. Kapitel 7 har fokus på SSPF som samverkansmodell och förutsättningarna för ett fungerande arbete. I sista resultatkapitlet, kapitel 8 ligger fokus på samspelet mellan samhällets aktörer och familjen i SSPF-modellen. Sista kapitlet i uppsatsen ägnas åt slutdiskussion. 


\section{Tidigare forskning och forskningsproblemet i sitt sammanhang}

Kapitlet presenterar några relevanta studier från det nationella och delvis internationella forskningsfältet vad gäller brottsprevention, samverkan och mer specifikt brottspreventiv samverkan på individnivå9. Urvalet av forskning har gjorts med utgångspunkt från syfte och frågeställningar i uppsatsen. Det betyder att genomgången börjar i en vidare kontext för att sedan smalna av mot det mer specifika. Detta för att förtydliga denna studies bidrag till forskningsfältet.

\section{Brottspreventionens utveckling}

Flera forskare (Sahlin 2000, Balvig 2004, Storgaard 2004, Garland 2010) menar att en tydlig svängning mot ökad kontroll skett vad gäller preventiva åtgärder och synen på orsaker och åtgärder och att detta hänger samman med övrig samhällsutveckling.

Den danske rättssociologen Flemming Balvig har med Danmark som exempel analyserat den förändring som skett över tid vad gäller synen på brott och brottsprevention. Hans hypotes är att den trend eller till och med paradigmskifte mot bestraffning och "hårdare tag" som skett de senaste decennierna inte kan förklaras enbart genom en högervridning $i$ politiken utan han menar att det är mer komplext än så. Människors levnadsvillkor har förändrats radikalt och därmed förändras det förhållningssätt och den relation man har till omvärlden. Han ger tre förklaringar till detta skifte: välfärdsstatens kris, främlingskap/distansering och individualisering. Välfärdsstaten har misslyckats med att komma till rätta med kriminaliteten och stora förändringar har skett vad gäller statens möjligheter att påverka människors liv, människors attityder har förändrats mot brottslingen och brottsligheten. Brott är inte längre sett som ett rop på hjälp; det tolkas i stället som ett tecken på risk (Balvig 2004, s. 181). Människor distanserar sig och sina liv från de som begår brott. Individualiseringen gör att individen känner en större frihet men också en ökad existentiell

\footnotetext{
${ }^{9}$ Utöver skandinaviska studier är det främst brittiska studier som presenteras.
} 
otrygghet. När den allmänna synen förändras påverkar också detta politiken menar Balvig vidare. Detta har varit en internationell och snabb trend i västvärlden som sist nådde de nordiska länderna, därför att välfärdsstaten var starkast i dessa länder och här fanns mer att förändra. Vidare påverkas brottspreventionen på så vis att långsiktiga strategier för att förebygga brott, liksom orsaksförklaringar blir ointressanta för såväl forskare som medborgare och politiker. Brottspreventionen blir i stället "ett emotionellt och demokratiskt trygghetsprojekt" (ibid s.182).

Paula Wahlgrens avhandling från 2014 har fokus på skolans brottsförebyggande roll och hur diskursen för brottsförebyggande arbete förändrats över tid. Med stöd av bland annat Ingrid Sahlin (2000), ser hon tre olika diskurser kopplade till olika tidsperioder. Under 1970- och 80-talet dominerade diskursen om det försummade barnet och sambällets svek, med betoning på ett mer inkluderande samhälle och långsiktiga förändringar som lösningen på brottsligheten. Under senare delen av 1980-talet och större delen av 90-talet kom det mer att handla om sveket mot sig själv genom oönskade beteenden. Avskräckning blev allt vanligare för att förmå unga att avstå från den brottsliga banan. Det försummade barnet nämns här mer $\mathrm{i}$ termer av att inte ingripa $\mathrm{i}$ tid vid normbrytande beteenden. Det egna ansvaret, såväl den vuxnes som barnets, blir alltmer omtalat. Efter millennieskiftet menar Wahlgren att diskursen alltmer kommer att handla om sveket mot sambället, den förlorade sociala kontrollen och behovet av att upptäcka och àtgärda problem. Betoningen, även inom kriminologin, kommer att ligga på kontroll och avvisande av komplexa förklaringar till brottsligt beteende (Wahlgren 2014). Utifrån Wahlgrens förklaringsmodell är det i denna era som samverkansmodeller som SSPF växer fram.

\section{Brottspreventiv samverkan}

Det skandinaviska brottspreventiva arbetet bygger i hög grad på samverkan mellan olika aktörer, vilket blir tydligt vid granskning av de brottsförebyggande rådens hemsidor, de dokument som varit styrande och vägledande samt den litteratur som finns i ämnet. Även i andra länder i väst, särskilt i Storbritannien, har forum och modeller för samverkan med syfte att minska brottsligheten växt fram. Detta sker 
utifrån övertygelsen om vinsterna med interprofessionellt samarbete, men också utifrån att krympande resurser och specialisering inom välfärdssektorn kräver fler "händer" och kompetenser för att nå framgång (Danermark \& Kullberg 1999, Forkby \& Larsen 2005, Williams 2009, Lindberg 2009).

Såväl svensk som internationell samverkansforskning (se t ex Danermark, Williams, Huxham \& Vangen) har identifierat framgångsfaktorer och försvårande faktorer för samverkan. Sammanfattningsvis påverkas utfallet av samverkan av faktorer gällande struktur, process, ekonomi och professioner. Detta gäller även för de samverkansformer som växt fram i brottsförebyggande syfte. Här betonas ofta även etiska problem som uppstår när information ska utbytas mellan samverkansaktörerna och man lyfter också fram de överlag ganska stora skillnader mellan professioner som gäller kultur, etik och ibland även hur av partnerskap och samverkan definieras av de olika aktörerna (Williams 2009).

\section{Nyare samverkansformer runt unga individer}

Intresset för brottsförebyggande arbete har ökat mycket i västvärlden de senaste 20 åren och strategier för detta har tagits fram (Forkby \& Larsen 2005). De senaste decennierna har olika former för samverkan inom välfärdsområdets organisationer, men också mellan organisationer växt fram på ett nästan explosionsartat sätt som blivit en utvecklingstrend (Johansson, S. 2011a, s. 15). Detta gäller även arbetet för att möta och hantera problematiken med ungdomskriminalitet och/eller missbruk inom brottsförebyggande arbete, såväl på nationell som lokal nivå. Denna samverkan kan ske såväl mer generellt brottsförebyggande eller i riktad form, antingen områdesinriktat eller individinriktat. I den här typen av samverkansarbete medverkar flera olika parter, till största delen från offentlig sektor. Skola, socialtjänst, polis och fritidsverksamhet är vanligast förekommande i de olika modellerna. 
På senare år har flera svenska doktorsavhandlingar som behandlar samverkan runt barn och unga $i$ utsatta livssituationer ${ }^{10}$ publicerats $i$ Sverige (t ex Johansson, S. 2011a, Edvall Malm 2012, Blomqvist 2012). Susanna Johansson, som i sin avhandling gör en kritisk analys av samverkan i så kallade Barnahus 11 menar att den nya typ av samverkansform som växt fram där polis och kommun samarbetar innebär en spänning mellan å ena sidan rättsapparatens brottsutredande och bestraffande syfte och å andra sidan socialtjänstens skyddande och behandlande syfte där "rättssystemet präglas av en idé om formell rättvisa och det sociala systemet präglas av en idé om helhetssyn och behandlingstänkande" (Johansson, S. 2011b, s. 39). Johansson menar vidare att socialtjänsten även hamnar $\mathrm{i}$ en egen spänningssituation eftersom verksamheten representerar såväl myndighetsutövning med tvångslagar som LVU - lag om vård av unga och LVM - lag om vård av missbrukare i vissa fall, som en stödjande och behandlande verksamhet. Det betyder exempelvis att en insats från socialtjänsten som inleds med en stödjande intervention för en ung person kan övergå i en tvångsåtgärd via LVU om en situation där uppstår i de fall då:

\section{den unge utsätter sin hälsa eller utveckling för en påtaglig risk att skadas genom missbruk av beroendeframkallande medel, brottslig verksamhet eller något annat socialt nedbrytande beteende (LVU 1990:52 §3).}

Disa Edvall Malm som behandlar just samverkan runt unga på väg in i kriminalitet, i detta fall samverkan mellan socialtjänst och polis, lyfter i sin avhandling fram flera forskare som ser dessa samverkanslösningar, eller handlingsnät som Edvall Malm kallar det, som resultatet av nyliberala strömningar i samhället. Hennes tolkning av de offentliga dokument som ligger till grund för dessa är att det går ut på dels kostnadseffektivitet för

\footnotetext{
${ }^{10}$ De refererade forskningskällorna rör inte endast brottspreventiv samverkan, men är relevanta utifrån att de handlar om samverkan runt enskilda barn och unga i utsatta livvsituationer.

${ }^{11}$ Barnahus är en "kontext där socialtjänst, hälso-och sjukvård samt polis- och åklagarmyndigheter samverkar under ett gemensamt tak kring utredningar av misstänkta brott mot barn" (Johansson, S. 2011 s.15).
} 
Polisen, dels betoningen på att skydda medborgarna från brott och brottslingar (Edvall Malm 2012).

I Storbritannien är det vanligt med riktad brottspreventiv samverkan, både på områdes- och individnivå. I en översikt av Iestyn Williams från 2009 analyseras flera olika modeller av riktade, det vill säga selektiva eller indikerade, samverkansformer inom området. Williams menar att olikheter i synsätt mellan professioner gällande etiska frågeställningar är de största svårigheterna $\mathrm{i}$ just denna typ av samverkan. Detta har dock inte uppmärksammats i någon högre utsträckning av statsmakterna, som ofta är uppdragsgivare för satsningar av detta slag (Williams 2009). Det gäller även spänningen mellan kontroll/straff och stöd. Här menar forskare i Storbritannien till exempel att Labours Crime and disorder act som kom 1998 gav dubbla budskap gällande kontroll/straff kontra stöd till kriminella ungdomar (Kelly 2012). I Storbritannien, liksom i många andra länder i västvärlden, är ungdomsbrottslighet en fråga som hör hemma mer i kriminalpolitiken än i socialpolitiken. En studie behandlar samarbete mellan Youth Offending Teams i England och Wales - vilka tidigare beskrivits är team bestående av en mängd olika samverkansparter som ska verka för en minskad ungdomskriminalitet - och projekt för stöd till drogmissbrukande unga. Studien visade tydligt på spänning, såväl vad gällde stöd/kontroll som etiska aspekter runt sekretess och liknande (Minkes $\mathrm{m}$ fl. 2005). Den svenska modellen för sociala insatsgrupper SIG- är inspirerad av Youth Offending Teams. En utvärdering av Youth Offending Teams - vilka startades 1999 med mycket stora förhoppningar och beskrevs som "nyckeln till framgång" - gjordes 2010. Resultaten av utvärderingen var dock relativt nedslående. Målen för satsningen hade inte i något fall uppfyllts (Pamment 2010).

Den här formen av intervention är med ovan beskrivna definition social brottsprevention riktad mot unga individer som bedöms vara $i$ riskzonen för att utvecklas negativt och fastna i kriminalitet och/eller missbruk. Individinriktad brottsprevention kräver att samverkansparterna har såväl kunskap som etisk kompetens. I en genomlysning av samverkansinterventioner av detta slag i USA och Europa, konstateras att det föreligger risk för stigmatisering och att ett noggrant arbete med analys och bedömning ska föregå interventionen (Socialstyrelsen 2012). Laura Kelly, som också sett över riktade 
brottspreventiva program i England menar att de brottspreventiva effekterna av dessa program överdrivs och att det föreligger risk för ytterligare stigmatisering av redan sårbara unga. Hon är vidare kritisk till att individualiseringen av problemen gör att de strukturella faktorer som ligger bakom ungdomskriminalitet tenderar att glömmas bort (Kelly 2012).

Ung \& Trygg i Göteborg är ett nyare exempel på brottspreventivt samverkansarbete i Sverige. Verksamheten startades 2004 och utökades 2005 till att omfatta alla stadsdelar i Göteborg med ett centralt kansli. Anledningen till denna brottspreventiva satsning var ökad gängrelaterad kriminalitet och det övergripande syftet var att förhindra nyrekryteringen till de kriminella gängen. Ung \& Trygg- arbetet har följts av FoU i Väst/GR med olika fokus. Bland annat poängteras där att ungdomsbrottslighet är ett föränderligt område vilket kräver en benägenhet hos samverkansparterna att också förändra sitt arbete. Vidare menar man att genom en intensifierad samverkan kan brister i det ordinarie arbetet hos deltagande parter bli synligt vilket kan bli känsligt. Man kunde också urskilja två grundpositioner bland samverkansparterna i de olika stadsdelarna- de entusiastiska och de avvaktande. Grundfrågan här handlade om huruvida man ansåg att arbetet med Ung \& Trygg var viktigt för att utveckla arbetet med målgruppen unga i riskzon (Forkby 2008).

Individ och familj i samverkan

Camilla Blomqvist (2012) är kritisk till hur föräldrar gjordes, eller snarare inte gjordes delaktiga i det som hände runt deras barn i samarbetet mellan BUP, socialtjänsten och skolan. Hon menar att föräldrar stod utanför den "förhandling" som pågick när det gällde vilka insatser som myndigheterna skulle bidra med. Ofta erbjöds föräldrarna andra insatser än de önskat när de sökte hjälp och många gånger förstod inte föräldrarna vad som skett i den så kallade "förhandlingen". Blomqvist menar vidare att delaktighet från föräldrar förutsätter, eller till och med handlar om, att de förstår vad som händer. Hon frågar sig också hur familjen märker skillnad av samverkan och för vem är nyttan med samarbetet? "Om samverkan är svaret - hur lyder då frågan?"

(Blomqvist 2012, s. 208). 
SSPF bygger, liksom en stor del av såväl det sociala arbetet som samverkansmodeller, på det fysiska mötet mellan företrädare för organisationer och mellan dessa och dem det berör; klienter, brukare osv. Det finns forskare som intresserat sig för denna möteskultur i sig (bl. a Basic m fl. 2009). Ibland har man särskilda möten mellan myndigheter före och efter själva huvudmötet och många gånger bygger interventioner för unga personer på en kedja av möten, där är SSPF inget undantag. Först ett möte på styrgruppsnivå, därefter möte på verksamhetsnivå där familjen och den unge deltar och sedan uppföljande möten. Denna struktur är uppbyggd efter organisationernas behov mer än behoven hos dem det berör, i detta fall ungdomar och deras familjer (ibid).

\section{Sammanfattning och reflektion}

Överlag kan sägas att den forskning som handlar om samverkan runt unga med ett riskfyllt beteende ofta landar i själva samverkan och inte i vad den leder till eller på vilket sätt de unga och deras föräldrar görs delaktiga i samverkan. Susanna Johansson (2011 a) beskriver, i sin avhandling om samverkan i Barnahus, att kunskapen om samverkan runt barn i utsatta livssituationer är mycket begränsad och sällan teoretiskt förankrad även om det blir alltmer vanligt med studier inom området. Dock vet vi ännu relativt lite om effekterna av samverkan, vad leder den till egentligen? Johansson betonar att det finns behov av kritiska analyser av samverkan (ibid). Detta bekräftas av flera samverkansforskare, Huxham \& Vangen (2005) menar till och med att samverkan både är resurskrävande och svår och därför ska undvikas om inte nyttan av den är tydlig och uppenbar.

Det finns en mängd studier av svenska samverkansprojekt, utvärderingar och liknande. Påfallande ofta handlar dessa om hur själva samverkan fungerat och inte om vad samverkan lett till i form av effekter eller hur brukaren upplevt dem. Det finns förklaringar till det, som att det är svårt att urskilja vilka eventuella effekter som beror på själva samverkan (Danermark 2011, Berghner 2014).

Om effekterna av samverkan i sig är svåra att konstatera är det samma sak med brottsförebyggande arbete menar exempelvis Jerzy Sarnecki (2004). Även om arbetet ibland är förankrat i kriminologisk teori betyder 
inte det med automatik framgång. Ingrid Sahlin hävdar i sin tur att den forskning som sker om brottsprevention i mångt och mycket är knuten till statliga och kommunala myndigheters behov av utvärdering av egna insatser och därför har avståndet mellan teorier om brottslighetens orsaker och själva brottspreventionen ökat avsevärt. Sahlin kopplar detta delvis till nedskärningar i välfärden - det vill säga de naturligt preventiva arenorna - och att det medfört mer kortsiktiga satsningar inom brottsförebyggande arbete. Åtgärderna är beroende av vilka politiska, ekonomiska och ideologiska förhållanden som råder och följaktligen är även forskningen beroende av detta (Sahlin 2000). Detta bekräftas av Wahlgren (2014) och de tre diskurser över tid som hon beskriver, från strukturella förklaringar till kontrollteorier.

Så sent som våren 2015 publicerades en utvärdering av implementeringen av SSPF i Göteborgs stadsdelar genomförd av FoU i Väst/GR. Där konstaterar man att arbetet ser olika ut - och att implementeringen varit varierat framgångsrik- i stadsdelarna. Det gemensamma är att man har styrgrupp och arbetsgrupp och vanligen arbetar med en så kallad genomförandeplan runt den unge men i övrigt ser SSPF ut på olika sätt (Turner $\mathrm{m}$ fl.2015). Det finns ännu inte någon forskning som visar att denna typ av brottspreventiv samverkan har önskvärd effekt. Trots detta startar fler och fler kommuner i Sverige SSPF-grupper eller Sociala insatsgrupper. I Danmark har SSP-arbetet utvärderats, dock omfattades inte det individriktade arbetet. Man konstaterade i utvärderingen från år 2000 att drogförebyggande arbete samt arbete mot ungdomskriminalitet är det som fungerar bäst när det gäller SSP-samverkan. Man konstaterade också att SSP-arbetet i Danmark innebär en stor valfrihet för kommunerna vad gäller insatser och metoder, vilket kan vara en nackdel då det kan innebära för många valmöjligheter. Man saknade också riktlinjer för en enhetlig linje i SSParbetet runt om i Danmark (Watt Bolsen 2000).

I Sverige finns relativt sparsamt med forskning om individriktade samverkanslösningar inom det brottspreventiva området och ännu mer blygsamt gällande den enskildes perspektiv i detta arbete. I evidensens tidevarv är inte SSPF evidensbaserat vare sig som metod eller form. Genom att med exemplet SSPF ur flera perspektiv studera och analysera individriktad samverkan, är ambitionen i denna studie att en lucka i 
kunskapsläget inom området ska fyllas. Ett område som behöver belysas mer är polisens till synes allt viktigare roll i det individriktade arbetet, ett annat är de eventuella samverkansvinster som ett arbetssätt som SSPF kan föra med sig för samverkansparterna och för familjerna. Genom att förstå brottspreventiv samverkan på individnivå i ljuset av samhällsutvecklingen och från ett organisatoriskt/professionellt perspektiv bidrar studien till kunskapsbilden. 


\section{Framväxten av individriktad brottsprevention}

I detta kapitel kommer jag att, med startpunkt i ett samhälleligt perspektiv, beskriva hur dagens brottspreventiva samverkan på individnivå och en modell som SSPF växt fram. Då SSPF bygger på en dansk modell och det finns många likheter i de skandinaviska länderna vad gäller brottsprevention, börjar beskrivningen i en skandinavisk ${ }^{12}$ kontext. Även Storbritanniens brottspreventiva arbete runt målgruppen har inflytande i Sverige, varför denna kontext också blir relevant.

Huvudfokus i kapitlet är dock framväxten av SSPF och liknande modeller i Sverige, med start i ett vidare perspektiv. I kapitel 6 kommer denna framväxt att analyseras med hjälp av relevanta dokument, varför detta blir en mer beskrivande del.

\section{Den nordiska modellen för brottsprevention}

Brottsligheten ökade markant under efterkrigstiden och särskilt under 1960-och 70-talen (Justitiedepartementet Ds 1996:59). I Skandinavien och övriga Norden betraktades detta som ett välfärdsproblem och brottsförebyggande arbete blev en framväxande gren av välfärdspolitiken under de senare decennierna av 1900-talet. Det var i sin tur grundat i övertygelsen om att rättssystemet i sig inte är brottsförebyggande och att ett inkluderande samhälle skapar mindre brottslighet. Synsättet menades vara speciellt för de nordiska länderna och den välfärdspolitik som bedrevs här, eftersom andra länder i västvärlden ${ }^{13}$ räknar brottsprevention till kriminalpolitik och inte till välfärds- eller socialpolitik. Detta synsätt utgjorde grunden för the Nordic model of crime prevention (Brå \& Nordiska rådet 2000). Gemensam utgångspunkt för brottspreventionen i de nordiska länderna har varit att rättssystemet endast har en marginell effekt för att förebygga brottslighet och därför behövs andra insatser. Arbete mot marginalisering och stöd till socialt

\footnotetext{
12 I texten lyfts, vid sidan av Sveriges brottspreventiva arbete, även Norge och Danmark fram. The Nordic model of crime prevention omfattar även Finland och Island, dock har jag valt att avgränsa fördjupningen till de skandinaviska länderna Sverige, Norge och Danmark. I samband med resonemang runt the Nordic model används dock begreppet Norden.

13 Här har jag mestadels studerat Storbritannien.
} 
utsatta människor samt arbete för jämlikhet har varit grunden i ett brottsförebyggande arbete, tillsammans med tidiga upptäckter av unga som far illa och satsning på social brottsprevention. Brottspreventionen ska vara kunskapsbaserad och utgå från medborgarnas bästa och deras villkor och ha ett trygghetsperspektiv på arbetet samt huvudsakligen ske på lokal nivå, det vill säga i kommunerna (Ds 1996:59, Justis- og politidepartementet 2008).

\section{En förändrad lagstiftning}

Det dokument som hänvisas till ovan - the Nordic model of crime prevention (Brå \& Nordiska rådet 2000), som beskrev de nordiska ländernas hållning och politik vad gällde brottsprevention- kom så sent som år 2000, då redan en rad förändringar i såväl välfärdssamhället som i det brottspreventiva arbetet skett. Detta belystes inte i dokumentet, vilket gör att det inte är lika relevant för att beskriva brottsförebyggande arbete i norden numera. Men det är ännu mycket som förenar de skandinaviska länderna i det brottsförebyggande arbetet.

Relativt stor likhet råder exempelvis mellan de skandinaviska länderna vad gäller lagstiftning kring ungdomskriminalitet (Stoorgard 2004). Den förändring som välfärdssamhället genomgått de senaste decennierna med individualisering och nyliberala strömningar har också påverkat diskursen för brott och brottsförebyggande arbete bland unga. Med detta menas bland annat att det skett en glidning från stöd till mer kontrollbaserad syn på vad som är framgångsrik prevention och detta påverkar också den praktiska tillämpningen av brottsprevention och annat förebyggande arbete (Wahlgren 2014 Balvig 2004, Storgaard 2004, Sahlin 2000, Edvall Malm 2012, Johansson, S. 2011a, b).

Samtliga länder i Skandinavien har fram till 2010 haft en straffmyndighetsålder på 15 år, utifrån en skyddsaspekt gällande yngre barn. Det betyder också att socialtjänsten ansvarar för största delen av de unga som begår brott, något som i andra delar av västvärlden oftast ligger på kriminalvården och rättsapparaten (Andersson \& Sallnäs 2012). Senare förändringar i lagstiftning med mera tyder dock på att vi i de skandinaviska länderna delvis går från en skyddsaspekt mer mot en straffvärdesaspekt på ungdomsbrottslighet. Det vill säga att där man 
tidigare såg behov av att skydda den unge mot destruktiv utveckling framträder nu skyddet till samhället alltmer, därav skärps talet om det individuella ansvaret hos den unge och därmed påföljder med mera. (Storgaard 2004, Balvig 2004, Sahlin 2000).

I Norge kom först 2011 en lagändring som medför införandet av ungdomsstraff, men ska användas som alternativ till fängelse, dock är straffet uppfordrande och innebär en hög nivå av kontroll (PROP $135 \mathrm{~L}$ 2010-2011). En svensk statlig utredning från 2012 föreslog nya påföljder för unga som begår brott; ungdomsövervakning och varningsstraff. Utredningen resulterade så småningom att en proposition kallad Tydligare reaktioner på ungas brottslighet (prop. 2014/15:25) presenterades. Där tar man fasta på flera av förslagen i utredningen, samt föreslår en lagreglerad samverkan mellan de myndigheter som handhar ungdomsbrott. Man föreslog också i den statliga utredningen att unga mellan 18 och 20 år i högre utsträckning än tidigare ska behandlas som vuxna av rättssystemet. I utredningen betonas också att huvudansvaret för de unga ska ligga kvar på socialtjänsten, men att samverkan mellan socialtjänst och rättskipande myndigheter ska stärkas och formaliseras ytterligare när det gäller unga (SOU 2012:34).

I Danmark sänktes straffmyndighetsåldern år 2010 från 15 till 14 år och 2010 kom en lagförändring i Sverige som innebar att barn under 15 år skulle kunna förhöras av polis och med tvång drogtesta dessa, ärenden som tidigare uteslutande överlämnades till socialtjänsten (prop. 2009/10:105).

Betydelsen av sekretess och samtycke

För att underlätta SSPF och liknande former av samarbete på individnivå som behandlas i uppsatsen, används ofta någon form av samtycke till informationsutbyte, vilket betyder att den unges vårdnadshavare och $\mathrm{i}$ vissa fall den unge själv ${ }^{14}$ samtycker till att samverkansparterna utbyter information om den unge. Detta är ett sätt att hantera sekretesslagstiftningen, som från olika håll lyfts fram som ett hinder $i$

\footnotetext{
${ }^{14}$ I de tre kommuner som omfattas i denna studie är det endast vårdnadshavare som skriver på samtycke då den unge är under 18 år.
} 
samverkan runt unga i utsatthet. I Sverige har relativt nyligen gjorts förändringar i sekretesslagstiftningen vilka innebär lättnader för socialtjänsten att i vissa fall överlämna uppgifter om unga under 21 år till polisen (SFS 2012:804). Även i Norge och Danmark har sekretesslagarna diskuterats livligt i det brottsförebyggande arbetet. Bland annat har kritiska argument som det riskerade förtroendet mellan socialarbetare och klient, risken för stämpling av unga samt bristen på kontroll över vilken information som byts lyfts fram (Stoorgard 2004). Samtycke till informationsutbyte framställs ändå ofta som själva grunden för arbetet med modeller som SSPF och som det som gör skillnad mot ett mer konventionellt sätt att arbeta med målgruppen.

Lokalt brottsförebyggande arbete utgör grunden

På nationell nivå finns brottsförebyggande råd och nationella dokument som ska vägleda och styra, dock betonas i de politiska dokument som ligger till grund för brottspreventionen i Skandinavien, vikten av det lokala arbetet - det vill säga det som sker i kommuner och stadsdelar (Ds 1996:59; Justis- og politidepartementet; 2008). I Sverige har de flesta av landets kommuner idag lokala brottsförebyggande råd, en del kommuner har valt att kalla dessa för trygghetsråd, det finns även andra benämningar. Råden bygger dock ofta på att såväl politiker som ledningsfunktioner från kommun och polis tillsammans med andra aktörer såsom föreningsliv, näringsliv med flera deltar.

Brottspreventiv samverkan överlag, men också på individnivå, har tagit fart i Sverige det senaste decenniet, då myndigheter på nationell nivå gått samman och uppmanat till gemensamt ansvar för unga som far illa eller riskerar att fara illa, vilket blir tydligt i dokument som ligger till grund för detta, bland annat överenskommelser mellan polis och kommun. 2007 togs en gemensam strategi för detta fram av dåvarande Myndigheten för skolutveckling, Rikspolisstyrelsen och Socialstyrelsen. Denna strategi presenterades i en metodskrift och innehöll såväl aktuell forskning om samverkan som råd för en framgångsrik sådan. Detta följdes bland annat av att Rikspolisstyrelsen tog fram en handlingsplan som manade sina polismyndigheter till en intensifierad brottsförebyggande samverkan med kommunerna (Socialstyrelsen $\mathrm{m}$ fl 2007, RPS 2008). En mängd överenskommelser mellan kommuner och 
polismyndigheter skrevs runt om i landets kommuner, där lyftes olika delar av det gemensamma ansvaret fram. Ungdomskriminalitet och droger är mycket vanligt förekommande områden att samverka kring $\mathrm{i}$ dessa dokument. I kapitel 6 analyseras denna typ av dokument.

\section{Riktad brottspreventiv samverkan runt unga individer och ungdomsgrupper}

Intresset för brottsprevention har ökat ytterligare i Skandinavien och Storbritannien och troligen också $i$ andra västländer under de senaste 15 åren. Såväl nationella som lokala program tas fram och samverkan mellan kommun och polis betonas som framgångskoncept (Forkby \& Larsen 2005, Edvall Malm 2012, Williams 2009, Kelly 2012).

Samverkansavtalen mellan kommun och polis har i Sverige bidragit till att nyare modeller för samverkan mellan parterna också på individnivå provas runt om i landet. SSPF är ett exempel på detta, SIG är ett annat (se t ex Johansson \& Henriksson 2013).

Olika satsningar på brottspreventiv samverkan runt ungdomsgrupper eller enskilda individer har initierats och genomförts i Skandinavien, liksom i exempelvis Storbritannien. SSP-modellen i Danmark är föregångare för flera av dessa satsningar, exempelvis samordning av lokale kriminalitetsforebyggende tilltak - SLT - i Norge och SSPF i Sverige. I Danmark läggs stor tyngd och mycket resurser i kommunerna på SSP-samarbetet mellan skola, socialtjänst och polis. SSP-konceptet är ett av de tidigaste exemplen i Skandinavien på interprofessionellt samarbete i brottsförebyggande syfte (Stoorgard 2004). SSP-arbetet i Danmark bedrivs såväl på generell nivå som på selektiv- och individnivå och mycket av arbetet är fältförlagt till skolor, fritidsgårdar och andra arenor där barn och unga vistas. Målgrupper för arbetet är såväl ungdomar som föräldrar och personalgrupper som möter unga, exempelvis lärare (DKR 2008). SSP i Danmark har således mer karaktären av samhällsarbete, även om arbetet också sker på grupp- och individnivå (Turunen 2004).

Även samarbetsmodeller i Storbritannien inspirerar det brottspreventiva samverkansarbetet i Skandinavien, vilket beskrivs närmare längre fram i kapitlet. 
Samverkan runt och för barn ${ }^{15}$ i utsatthet, barn som far illa eller riskerar att fara illa är i Sverige en lagstadgad skyldighet och regleras $i$

lagstiftningen för polis, förskola och skola, socialtjänst samt hälso- och sjukvård $^{16}$. Det finns officiella dokument redan från såväl 40-, 50-, 60och 70-talen som beskriver hur samverkan mellan polis och sociala myndigheter, samt i det sista fallet även skolan skall ske när det gäller att förebygga brott (Edvall Malm 2012). Samverkan mellan myndigheter och andra aktörer i brottsförebyggande arbete är också idag en självklarhet och det förutsätts ge såväl bättre som snabbare resultat genom att undvika "stuprörsarbete" ${ }^{17}$ och liksom all samverkan utnyttja resurserna på ett effektivare sätt (Danermark \& Kullberg 1999, Bergmark \& Lundström 2008). Styrning, struktur och samsyn är ledord för fungerande samverkan runt unga i utsatthet (Danermark \& Germundsson 2007, Socialstyrelsen $\mathrm{m}$ fl. 2007).

Det mer konventionella samarbetet runt unga i utsatta livssituationer mellan polis, skola och socialtjänst har bestått $i$ att polis eller skola gör en orosanmälan till socialtjänsten, som sedan hanterar ärendet enligt gängse ordning. Det innebär bedömning och eventuell utredning, varpå beslut om insats från socialtjänsten fattas. I utredningsskedet förekommer ofta att socialtjänsten inhämtar information från skola, BUP, familj och så vidare. Ibland fortsätter samarbetet med olika instanser för att arbeta framåt runt den unga individen. Vid misstanke om brott håller polisen förhör med den unge där socialtjänst och vårdnadshavare bjuds in att delta. I den nyare typen av samverkansformer, där SSPF är ett exempel, är det alltså vanligt att polisen finns med i samverkansarbetet runt målgruppen även på individnivå. Som tidigare nämnts är det ofta är det

\footnotetext{
15 Barn är i lagstiftarens mening 0-18 år. I socialtjänstlagen omfattas i vissa fall även unga upp till 20 år.

${ }^{16}$ (1 kap. 2a § första st. SkolL (1985:1100); 2 f § första st. HSL (1982:763); 2 kap. 1 § LYHS (1998:531); 3 § PolisL (1984:387; 3 kap. 1,4, 5 §§ och 5 kap. 1a § SoL (2001:453).

17 "Stuprörsarbete" är ett vanligt förekommande begrepp inom praktiken i offentlig sektor. Begreppet innebär motsats till samverkan, det vill säga att varje organisation/myndighet arbetar var för sig med frågor som kan vara gemensamma.
} 
just polisen som initierar den här typen av samarbete, i Sverige med hänvisning till rikspolisstyrelsens handlingsplan från 2008 och samverkansöverenskommelserna.

Sociala insatsgrupper - SIG

En samverkansform som liknar SSPF och därför bör nämnas här, kallas sociala insatsgrupper - SIG och provades under $2012 \mathrm{i}$ tolv kommuner i Sverige. Målgrupp för sociala insatsgrupper är unga på väg in i kriminella nätverk och SIG föreslogs som intervention i utredningen Kriminella grupperingar. Motverka nyrekrytering och underlätta avhopp (SOU 2010: 15), vilket resulterade i ett regeringsuppdrag till Rikspolisstyrelsen. I en utvärdering av projektet konstateras bland annat att samverkansformer utvecklats, att kunskapen gällande effekterna efter så kort tid är liten samt att åldersgruppen 15-25 inte är så lyckad då förebyggande arbete bör starta före 15 års ålder och eventuella avhopp blir aktuella först efter 25 års ålder (Wollter $\mathrm{m} \mathrm{fl.} \mathrm{2012).} \mathrm{Sociala} \mathrm{insatsgrupper} \mathrm{har} \mathrm{permanentats}$ i flera kommuner och på vissa håll finns såväl SSPF som SIG, men de två modellerna riktas mot lite olika målgrupper beroende på allvaret $\mathrm{i}$ oron och ibland beroende på ålder. Ofta är ungdomar som aktualiseras för SIG mer etablerade i kriminella nätverk eller liknande, medan ungdomar som blir aktuella för SSPF kan vara i ett begynnande skede av en negativ utveckling, även om det ibland gått längre än så. Inspirationen till samverkansformen SIG är till stor del hämtad i Storbritannien, där informationsutbyte mellan myndigheter- inklusive polis- varit vanligt sedan 90-talet. Detta gäller såväl child protection som youth justice och är klart uttalat $\mathrm{i}$ the Children act 2004. Grunden för "the duty to collaborate" ligger i flera uppmärksammade dödsmisshandelsfall av barn, vilket resulterade i en ökad öppenhet mellan myndigheter (Parton 2005). Detta genomsyrar också the Criminal Justice act från 2003, där ungdomskriminalitet särskilt behandlas. Vad gäller modeller för brottspreventivt samarbete i Storbritannien, så har myndigheterna där bland annat tagit fram Multi-Agency Public Protection teams, MAPPA som arbetar såväl med tidiga upptäckter och insatser för unga som med återfallsförbrytare. En modell som ligger nära och som fokuserar på ungdomar är Youth offending Teams - YOT. Utgångspunkt i arbetet är riskparadigmet samt skydd för allmänheten, men forskare menar att det $\mathrm{i}$ 
arbetet även bör tas hänsyn till välfärdssystemet och de delar som gäller barn som omfattas där, eftersom YOT omfattar barn och unga i hög risk för kriminalitet (Monk 2009). Ett alltmer ökat fokus på tidiga upptäckter av barn och unga i riskzon finns i Storbritanniens länder, liksom i de skandinaviska länderna (Parton 2005). Olika typer av samverkansformer runt barn och unga har tidig identifikation av dessa unga som uttalat syfte. Detta gäller även SSPF.

\section{SSPF - samverkansform för snabbare agerande}

SSPF- samverkan mellan skola, socialtjänst, polis och fritidssektorbygger som tidigare nämnts på den danska förebild - SSP - som beskrevs ovan. I Sverige har arbetet tagit en delvis annan form, då den svenska modellen i högre grad än i Danmark fokuserar på individer. I det svenska arbetet har man också i många kommuner till bokstaven $\mathrm{F}$, utifrån tanken om att fritiden är en viktig del av den unges liv och att bra fritidsaktiviteter kan fungera förebyggande i sig, en skyddsfaktor. SSPFmodellen används i ett flertal kommuner runt om i landet. Malmö och Göteborg hör till de första kommunerna i Sverige som under andra halvan av 2000-talet introducerade arbetsformen SSP $(\mathrm{F})^{18}$. Modellen beskrivs som en kraftfull insats från samhället i de fall när stark oro förekommer för unga som är på väg in- eller redan finns i - missbruk och/eller kriminalitet och ska, tack vare samverkansvinsterna, bli mer effektfull än tidigare försök att stödja dessa barn och ungdomar. Genom samlade resurser och snabbt agerande ska gemensamma lösningar runt den unge hittas. Med resurser menas såväl personer i det närmaste nätverket som funktioner inom de samverkande myndigheterna (Mellanstad 2014).

Aktuella för SSPF är således ungdomar där det bedöms att flera av aktörerna behöver agera ${ }^{19}$. Ärenden till SSPF kan anmälas från var och en av samverkansparterna och ska ha hög prioritet. Hur gången i ett

\footnotetext{
18 I Malmö använder man SSP, alltså utan fritidssektorn.

19 Ungdomsärenden kan vara såväl på individ- som på områdes- och gruppnivå. I denna uppsats behandlas endast arbetet på individnivå.
} 
ärende kan se ut beskrivs längre fram $i$ uppsatsen men redan nu kan sägas att det inte finns någon specifik mall för hur detta går till.

\section{Sammanfattning och reflektion}

Kapitel 3 har beskrivit framväxten av brottspreventivt samverkansarbete och specifikt det som sker på individnivå. Förebyggande arbete runt enskilda ungdomar, där polisen har en central roll är sålunda ett relativt nytt fenomen i Sverige sett till de senaste 30 åren, medan detta varit aktuellt i flera år i exempelvis Storbritannien.

Man kan därmed säga att SSPF i Sverige har hämtat inspiration främst från den danska modellen SSP, men även delvis från det brottsförebyggande arbetet med olika modeller i Storbritannien. Då Storbritanniens brottsförebyggande arbete legat inom ramen för rättsväsendet och det skandinaviska mer inom ramen för socialtjänsten, framträder nu en förändring mot ett skandinaviskt brottspreventivt arbete som mer och mer liknar övriga västvärldens. En brottspreventiv diskurs med allt mindre betoning på strukturella faktorer och alltmer på individuella samt en svängning från stöd mot mer straff och kontroll.

Brottspreventiv samverkan runt unga individer, där SSPF är ett exempel, är inte endast ett arbetssätt, utan såväl samhällsutveckling som organisatoriska förhållanden har betydelse för att - och på vilket sätt detta arbete utvecklats. 


\section{Teoretiska perspektiv}

Detta kapitel behandlar de teoretiska perspektiv och begrepp som är till stöd för analys och tolkning i studien. Även här utgår jag från de tre fokusområden som beskrevs i inledningen (figur 1). I kapitlet redogörs till att börja med för de perspektiv som är till stöd för min analys av framväxten av brottspreventiv samverkan på individnivå och hur brottsprevention bör ses i ljuset av förändringar i samhället i stort. Begrepp från nyinstitutionell teoribildning och Ingrid Sahlins typologi över brottspreventiva modeller gällande insatser är särskilt relevanta på den övergripande nivån, men återkommer även på de övriga nivåerna. Detta gäller även några ytterligare begrepp.

SSPF bygger på samverkan och interaktion mellan olika organisationer. Detta innebär att arbetet blir komplext och för att förstå detta är det nödvändigt att använda teoribildning om organisation och samverkan, vilket behandlas därnäst i kapitlet. Slutligen behandlas begrepp som är till stöd för analysen av interaktionen mellan samhällets aktörer i SSPF-praktiken och familj.

\section{Förändrat samhälle - förändrad brottsprevention}

I kapitel 3 återgavs vad som år $2000 \mathrm{i}$ the Norcic Model of Crime Prevention beskrevs utmärka det nordiska brottsförebyggande arbetet och vad som sades skilja detta från övriga västvärldens, nämligen att grunden för nordisk brottsprevention ligger i den generella välfärdspolitiken samt att brottsprevention är en socialpolitisk fråga och inte en rättspolitisk (Brå \& Nordiska rådet 2000). Stora samhällsförändringar har skett de senaste årtiondena och det har också skett påtagliga förändringar i den allmänna synen på brott och brottsförebyggande arbete. I kapitel två beskrevs en utveckling gällande lagstiftning med mera som tyder på att synen på ungdomsbrottslighet hårdnat och dras mot straffvärde gentemot ungdomar, snarare än skyddsvärde (Balvig 2004, Edvall Malm 2012) och att socialpolitiken alltmer flyter ihop med kriminalpolitiken (Forkby \& Larsen 2005). 
Talet om tidiga upptäckter av normbrytande beteende hos unga blir också allt vanligare i det brottsförebyggande arbetet. Ett begrepp som blir användbart när det gäller tidiga upptäckter och insatser gällande unga i riskzonen är net- widening (Cohen 1985, Kelly 2012). Detta bygger på ett resonemang om att samhällets kontrollsystem utökats till att omfattas av familj, skola, socialtjänst och andra vardagliga aktörer i samhället kontrollsystem "under cover" (Cohen 1985 s.163). Det gör att gränserna suddas ut mellan prevention och intervention och att fler och fler fångas i nätet som blir alltmer utspritt.

\section{En typologi över brottspreventiva insatser}

Till stöd för analys på en övergripande nivå används tillsammans med ovanstående begrepp och resonemang, en typologi över brottspreventiva insatser - eller modeller - av Ingrid Sahlin (2000). Utifrån beskrivningen av den förändrade synen på brottsprevention menar Sahlin att det $\mathrm{i}$ högsta grad är ideologiskt och politiskt betingat hur man ser på och tillämpar brottsprevention. Hon använder till och med begreppet människosyn, när hon presenterar sin typologi över olika brottspreventiva modeller för brottspreventiva insatser och aktiviteter:

Figur 2: Ingrid Sahlins typologi över brottspreventiva modeller

\section{Åtgärdens objekt}

Förutsättningar

$$
\text { 1. Förändring av }
$$$$
\text { stukturer/miljö }
$$

värde

\section{Effektivisering av 4. Kontroll} institutioner 
Här finns två alternativa övergripande värden att utgå från när samhället ska planera brottsförebyggande insatser. Dessa värden är antingen individens frihet och välfärd eller sambällets ordning, något av dessa värden dominerar menar Sahlin. Likaså finns två alternativa objekt för de brottspreventiva insatserna, antingen vill man komma åt och förändra de förutsättningar som råder mer strukturellt, eller så vill man påverka människors beteende. När syftet med brottspreventiva åtgärder är att påverka individers beteende används antingen insatser som syftar till socialisation, som ska främja en god utveckling för individer på sikt, eller insatser som syftar till kontroll, vilket är kortsiktigt och snabbt. Om siktet i stället är inställt på förutsättningarna för individens förändrade beteende är det antingen strukturinriktade insatser för en god socialisation, eller institutionsriktade insatser med syfte att effektivisera kontrollen och förutsättningarna för den. Det överordnade värdet för strukturella förutsättningar handlar om individens välfärd och/eller frihet, medan det överordnade värdet för effektivisering av institutioner är samhällets ordning. Ovanstående resonemang hjälper främst till i analysen av framväxten av en arbetsmodell som SSPF såsom den tolkas i de studerade dokumenten.

\section{Nyinstitutionell teori och begrepp}

I nyinstitutionell teoribildning i skandinavisk tappning (Ahlgren 2014) talas ofta om en idés resa och översättning, man intresserar sig för hur idéer sprids. En idé utgår här från ett upplevt behov och till något som redan är känt (Czarniawska \& Joerges 1996, Ahlgren 2014). I någon kontext skapas en idé, det kan exempelvis vara en idé om organisering eller iden om kunskapsutveckling i socialtjänsten (Johansson, K. 2013). I detta fall gäller det idén om brottspreventiv samverkan runt enskilda ungdomar. Det kan beskrivas som att idén förpackas, färdas från en kontext - exempelvis den nationella - till en annan - exempelvis den enskilda kommunen - packas sedan upp och översätts till den nya kontexten (Johansson, R 2006, Linde \& Svensson 2013, Czarniawska \& Joerges 1996, Ahlgren 2014). I den lokala kontexten anpassas idén efter de förutsättningar, den organisering och de personer som verkar där. 
Detta är tillämpbart på lanseringen av brottspreventiv samverkan på individnivå och hjälper till i gestaltningen av den specifika idéns resa och översättning från nationell till lokal nivå, särskilt i analys och tolkning av dokument.

Interaktionen mellan organisationer och dess förutsättningar i nyinstitutionell tappning

I detta avsnitt behandlas de teoretiska perspektiv och begrepp som använts för att besvara frågeställningar inom fokusområdet organisation/profession. För att utifrån empirin besvara frågeställningen om hur SSPF-modellen upplevs av samverkansparterna och hur de organisatoriska villkoren ser ut för att lyckas med modellen behövs specifika teorier.

Det är svårt att tala om organisationer och interaktion mellan dessa utan att komma in på nyinstitutionell teoribildning. Begreppet human service organisations - människobehandlande organisationeråterkommer i många studier som rör samverkan (Hasenfeldt 1983). Begreppet omfattar organisationer i välfärdssamhället som arbetar med människor som sitt huvudsakliga "råmaterial" (Danermark \& Kullberg 1999 s. 59) och omfattar därmed alla de samverkande organisationerna i SSPF-modellen.

Organisatoriskt fält är ett begrepp, som i samverkanssammanhang handlar om att flera organisationer möts och arbetar med samma målgrupp och liknande syfte. Ett fenomen som kan inträffa i ett organisatoriskt fält är att organisationer som arbetar inom samma fält tenderar att bli mer lika varandra (DiMaggio \& Powell 1982, Johansson, R. 2006). Organisationerna i fältet utvecklar normer och principer som liknar varandras och det är de stora och dominerande organisationerna på fältet som har tolkningsföreträde, en typ av samverkansmakt i detta fall. Dock ska inte organisatoriskt fält sammanblandas med samverkan (Linde \& Svensson 2013). Det organisatoriska fältet i studien är brottspreventivt arbete på individnivå, där aktörer från flera organisationer ska åstadkomma förändring för de unga som är målgruppen. Dessa aktörer kommer från organisationer med olika kultur och styrande lagar och detta kan, vid sidan av likriktningen också göra att spänning uppstår i SSPF- arbetet. Här kommer begreppet institution till 
användning, det används ofta $\mathrm{i}$ institutionell teoribildning vid sidan av begreppet organisation. Dessa begrepp kan uppfattas synonymt, men kan också beskrivas som att "en organisation konkretiseras i en uttalad struktur med befattningar, rollinnehavare och byggnader" medan institutionen kan betraktas som en "abstraktion, bestående av regler, normer och tankemodeller" (Linde \& Svensson 2013, s.13 med hänvisning till Scott 2008).

Interaktion mellan organisationer kan se ut på olika sätt. Det är inte organisationerna själva som samspelar och samverkar, utan individerna som finns i organisationerna, som i studien benämns de olika aktörerna. Organisationer kan också vara aktörer, men är det alltid genom de människor som finns där och som handlar kollektivt. Enskilda aktörer, även individer, har tolkningsutrymme vilket påverkar handlingar men också förväntningar från andra aktörer i samspelet vilket i sin tur påverkar hur vi handlar. Dessa aktörer representerar sin organisation och ska därmed representera de värden, regleringar och synsätt som organisationen står för. Detta, tillsammans med andra aktörers förväntningar på organisationen bildar den institutionella logiken. Här kan spänningar uppstå mellan de olika logiker som har institutionaliserats i de olika organisationerna (Scott 2008, Grape 2006, Linde \& Svensson 2013). I en samverkan där socialtjänst och polis arbetar nära kan dessa spänningar handla om de olika logiker som är grundläggande för institutionerna, men också för beslutsfattande; exempelvis den straffrättsliga logiken för polisen och behandlingslogiken för socialtjänsten (Johansson, S. 2011a, 2011b, 2013). Paradoxalt nog kan i en nära samverkan även likriktning uppstå, det vill säga att organisationer som verkar inom samma organisatoriska fält tenderar att bli mer lika varandra, detta kallas isomorfism (DiMaggio \& Powell 1982) i den nyinstitutionella teoribildningen. Det betyder att likväl som spänningar och konflikter kan förekomma i SSPF-samverkan, så kan en tendens av likhet mellan organisationer och dess aktörer uppstå, vilket denna studie också visar prov på. 


\section{Samverkansteori}

De förändringar som sker i samhället i stort vad gäller ideologi, trender och attityder påverkar också den lokala nivån, där offentliga organisationer inom välfärdssektorn har att förhålla sig till dessa förändringar samtidigt som den lokala nivån också påverkar den övergripande nivån. Tidigare behandlades det förändrade välfärdssamhället och hur det bland annat har medfört att samverkan blivit en allt viktigare arbetsform i dagens välfärdssamhälle (Danermark \& Kullberg 1999, Lindberg 2009).

Till hjälp för tolkningen av samverkan i denna studie, används en modell av Jan Horwath och Tony Morrison (2007), som omfattar flera tänkbara nivåer där strävanden efter samverkan kan landa. Modellen är utarbetad utifrån studiet av just samverkan runt utsatta barn. Samverkan (collaboration) är både komplex och tvetydig och måste undersökas med den utgångspunkten. Modellen innehåller fem möjliga nivåer av samverkan. Den lägsta nivån- kommunikation - innebär i princip att representanter från olika organisationer talar med varandra. På denna nivå finns inga eller mycket begränsade överenskommelser om samverkan och ofta handlar det om individfokus. Nästa nivå - samarbete (co-operation)- innebär en något högre nivå på det formaliserade samarbetet och även intensiteten i det. Ytterligare en nivå är samordning (co-ordination), då fler från respektive organisation är involverade och också personer på fler nivåer, men det är inte säkert att samverkan formaliserats eller att en organisation som drar sig ur får någon form av sanktion. Den fjärde nivån av samverkan är koalition (coalition), här finns gemensamma strukturer, den enskilda organisationen kan offra autonomi till fördel för samverkan och ofta ingår man mer formaliserade avtal, intensiteten i samverkan är högre. Den högsta nivån - integration, innebär att det alltid finns formaliserad samverkan genom avtal, att samverkan alltid går före den enskilda organisationens intressen, det finns uttalat mandat från högsta nivå och man fattar alltid beslut gemensamt. Det kan uttryckas som att organisationerna gemensamt går in i en ny identitet (Edvall Malm 2013). Horwath \& Morrison menar att bakgrundsfaktorer såsom gemensam historia, informella nätverk och annat blir betydelsefullt för framgången. Likaså har mandat, ledarskap, delaktighet, 
gemensamma mål och strategisk planering avgörande betydelse för högre nivåer av samverkan (Horwath \& Morrison 2007).

Strävan efter en gemensam mening finns i organisationer och även mellan organisationer. Ett organisationsteoretiskt begrepp som beskriver detta är sensemaking, meningsskapande (Weick \& Sutcliffe 2005). För detta krävs interaktion mellan människor, dessa skapar sin mening till de händelser som förekommer i mötet mellan dessa människor med olika värderingar, bakgrund och erfarenheter. Det handlar mycket om att människor skapar sin identitet tillsammans med andra och där orsak till gemensamt meningsskapande finns, underlättas det av samhandling, det vill säga att vi också agerar tillsammans med dem vi interagerar med. Meningsskapande främjar samhandling men kan också vara ett resultat av detta (Weick 1995; Andersson, L 2010).

Det finns ytterligare en aspekt i samverkansprocessen som beaktas $i$ studien. Även om samverkan nått en högre nivå enligt modellen ovan, är det inte självklart att samverkan är jämlik. En maktaspekt finns alltid med, vilket mandat man har, vem "tjänar mest" på samverkan, vem har tolkningsföreträde och så vidare. Ett antal möjliga orsaker finns till denna obalans vad gäller makt i samverkansprocessen. Det kan röra sig om de olika bilder parterna har av samverkansobjektet, professioners olika status, lagar och regelverk med mera (Danermark 2004). Till detta kommer givetvis den makt som samtliga samverkande organisationer har i förhållande till klienter/brukare, i detta fall ungdomar och föräldrar (Järvinen 2002). Denna aspekt blir viktig att beakta då det handlar om nästa fokusområde, interaktionen mellan praktik och familj.

\section{Implementering}

Svårigheter med implementering kan sökas på såväl individ- som organisationsnivå (Alexandersson 2006), återigen handlar det om hur en idé packas upp och översätts i den lokala kontexten, vilka aktörer och behov som finns där. I samverkansarbete handlar det också om i vilken mån man är enig om problembeskrivningen gällande det man ska samverka kring (Matland 1995). 
Interaktionen mellan samhällets aktörer och familjen

För analys av samspelet mellan organisatorisk/professionell nivå och

familjen har jag valt ett begrepp som är användbart i detta fall men även när det gäller relationen mellan de professionella aktörerna i SSPF.

Begreppet, som används bland annat av Torbjörn Forkby, är alliansbildning, vilket handlar om mobilisering kring den unge med ordnade strukturer (Forkby 2005, s. 116). Forkby hänvisar där till Ingrid Sahlin som talar om "de präktigas allians" där myndigheter och medborgare samverkar i brottsförebyggande syfte vilket innebär mindre inflytande för individen. Alliansen integrerar dem som ska utöva kontrollen och avskiljer dem som ska kontrolleras (Sahlin 1992 s. 70). Alliansbildningen kan också handla om att de goda krafterna mobiliseras runt exempelvis en ung person (Forkby 2006, Forkby \& Larsen 2005). Dessa allianser bestående av samhällets aktörer går ut på att skapa strategier för problemlösning runt olika sociala problem, där ungdomskriminalitet kan vara ett. Allianserna kan ha två huvudspår, där ett är ett strategiskt samordnande av aktörernas resurser och ett annat spår handlar om utveckling av nya arbetssätt (Forkby 2006). I fallet med SSPF gäller detta alltså ungdomarna och i alliansen ingår såväl myndigheter som föräldrar och ibland föreningslivet. Alliansen behöver således inte endast syfta till kontroll, utan kan också vara ett sätt att ingjuta nytt hopp i den unge och familjen - en "allians av god tro" (ibid, s. 26).

\section{Antaganden om SSPF}

Som ett komplement till ovanstående teorier och begrepp används delar av programteori eller programlogik (Vedung 2009, Rogers 2011, Hjelte $\mathrm{m}$ fl. 2014) för att tydliggöra de tänkta intentionerna med SSPF samt i den mån det är möjligt, hur dessa överensstämmer med resultaten $\mathrm{i}$ studien. Det vill säga, vilka antaganden finns gällande SSPF hos aktörerna avseende målgrupp, insatser och resultat och vad säger studien om detta (Hjelte m.fl. 2010)? I kapitel 1 (tabell 1) redogjordes för de antaganden om SSPF som framkommit utifrån studiens empiri, detta kan sägas vara aktörernas anammade teori, så som aktörerna beskriver arbetet när de blir tillfrågade. Det kan sedan jämföras med det som 
framkommer vid uppföljning eller studie av en specifik verksamhet bruksteori, som beskriver vad som sker i det reella arbetet.

Överensstämmer den anammade teorin med bruksteorin, vad aktörerna tänker och säger att de gör om de får frågan och vad de verkligen gör och vad som styr de reella handlingarna(Argyris \& Schön 1977)?

\section{Sammanfattning}

I kapitlet presenterades teorier och begrepp som används till stöd för analys och tolkning av det empiriska materialet i tre fokusområden. Teori på övergripande nivå handlar till stor del om den spänning mellan stöd och kontroll som blivit alltmer tydlig i det brottsförebyggande arbetet av idag. För att i övrigt fånga komplexiteten i SSPF-arbetet är nyinstitutionell teoribildning ett användbart perspektiv. Det blir tydligt att idén om brottspreventiv samverkan runt unga individer och dess tillämpning gör en resa från internationell och nationell nivå till den lokala kontexten, där den anpassas efter de förutsättningar som råder och till de personer som verkar där. Övriga begrepp i teoribildningen stödjer utvecklingen av resonemang kring vad som händer när olika organsiationer och dess aktörer ska samarbeta mot ett gemensamt syfte och med en gemensam målgrupp, som i fallet med SSPF.

Samverkan i sig kräver också ett teoretiskt perspektiv, för denna studie är Horwath \& Morrisons (2007) modell användbar som komplement till övrigt resonemang. Begreppet alliansbildning (bl a Forkby 2006) är relevant för studien såväl när det gäller den professionella alliansen som den som rör interaktion mellan praktik och familj.

Teorier och begrepp är huvudsakligen kopplade till respektive fokusområde men används ibland återkommande i andra resonemang, då det inte går att hålla isär fokusområden strikt, utan de är relevanta för varandra. Flera nivåer av analysområden kräver fler perspektiv och begrepp för att stödja tolkning och argumentation. Dessa har växt fram under studiens gång och var inte självklara från början, men vart och ett av dessa fyller sin funktion i framställningen. 


\section{Metod}

Kapitlets syfte är att beskriva överväganden och vägval gällande materialinsamling, analys och tolkning. Ambitionen är att processen ska bli så transparent och tydlig som möjligt. Metodologiska resonemang gällande den kvalitativa ansatsen och teorival inleder kapitlet, därefter redogörs för urval, materialinsamling, analys och tolkning. Till sist diskuteras metodproblem/begränsningar och etiska överväganden samt studiens giltighet.

Upprepade systematiska litteratursökningar har genomförts under studiens gång ${ }^{20}$.

\section{Metodologiska överväganden och begränsningar}

Studien har en kvalitativ ansats, vilket bland annat innebär att data som samlas in, systematiseras och sedan tolkas genom aktiv medverkan av forskaren. I kvalitativ forskning strävar man efter en helhetsbild av det som undersöks - individer eller situationer och för detta ändamål finns flera möjliga metoder (Larsson 2005). Studien präglas också av ett abduktivt förhållningssätt, det vill säga att teoribasen har växt fram under resans gång, då empirin fått tala och teoretiskt stöd för tolkning av empirin inhämtats successivt. Det fanns inte ett självklart teorival i början av processen, teorier och begrepp har växt fram succesivt, vissa har testats och lämnats därhän, det empiriska materialet har hela tiden varit vägledande för framskridandet av arbetet. Man kan också uttrycka det så att det har skett en vandring fram och tillbaka mellan den empiriska källan och det teoretiska ramverket (Bryman 2002).

${ }^{20}$ De studier som presenteras är resultat av återkommande litteratursökning där relevanta sökord prövats och använts. Med hjälp av bibliotekarien vid campusbiblioteket valdes databaserna Libris, Sociological abstracts och Unisearch för sökning. Olika begrepp inom brottspreventiv samverkan användes som sökord, med utgångspunkt från såväl samverkan som brottsprevention. Relevanta referenser i artiklar och studier har också prövats och använts. 


\section{Förförståelse}

En forskare behöver ständigt reflektera över sin roll i förhållande till forskningsobjektet Jag har många års erfarenhet av socialt arbete bland unga, såväl förebyggande som behandlande. Det har påverkat valet av forskningsproblem och -objekt, men kan också påverka mig i tolkning och förståelse för de resultat jag uppnår med studien, då erfarenheten från praktiken är avsevärt mer omfattande och kan färga förhållningssättet till forskningsobjektet. Här gäller att under hela forskningsprocessen reflektera över rollen som forskare kontra rollen som socialarbetare- vilka glasögon har jag på mig? Jag vill dock hävda att förhållningsättet till forskningsobjektet förändrats under resans gång, från att vara ganska okritiskt till att bli mer ifrågasättande, detta samtidigt som jag utvecklats som forskare. Här har jag också haft hjälp av forskarkollegor som påminner om detta dilemma vid seminarier och liknande.

$\AA$ andra sidan har erfarenheten från den sociala praktiken, där samtalet ofta är det verktyg som används, enligt min uppfattning varit till fördel i materialinsamlingen, både i intervju i grupp och individuellt. Holstein \& Gubrium (1995) menar att den så kallade förförståelsen kan ha en positiv inverkan på intervjun både vad gäller att förstå intervjupersonens perspektiv men också för att delad kunskap och delade perspektiv ger bättre förutsättningar för samproduktionen av kunskap under intervjun och det är detta som jag menar varit till fördel.

\section{Undersökningsobjekt och urval}

SSPF används år $2015 \mathrm{i}$ ett antal kommuner ${ }^{21}$ och stadsdelar runt om i Sverige. I studien ingår tre kommuner, varav en är en stadsdel i en storstad, en är en större stad och den tredje är en liten kommun ${ }^{22}$.

\footnotetext{
${ }^{21}$ Det är svårt att få fram exakt antal kommuner i Sverige som arbetar med SSPF. Frågan har ställts till BRÅ- Brottsförebyggande rådet, men där menar man att det finns flera liknande samverkansformer och att kommunerna ibland arbetar med SSPF men kallar det något annat.

22 Den lilla kommunen - Lillestad har ca 5000 invånare, den större kommunen - Mellanstad ca 130000 och Storstadsdel ca 30000.
} 
Kommunerna är inte slumpmässigt utvalda, utan man kan säga att det rör sig om ett bekvämlighetsurval, där kommuner som jag kommit i kontakt med och som arbetar med SSPF kontaktades om deltagande. Samtliga var positiva. Kommunerna är i olika faser av sitt SSPF-arbete, den mindre kommunen är i början av processen, den större har efter omorganisation nystartat och arbetat med SSPF i ungefär 2 år och stadsdelen i storstaden har flera års erfarenhet av SSPF-arbete.

För att få till stånd intervjuer med samverkansparterna har kontakt tagits med SSPF-koordinator eller liknande i respektive kommun. Dessa har sedan varit behjälpliga i att gruppintervjuerna med samverkansparterna kunnat genomföras genom att kontakta dessa eller förmedla kontakt. Organisatoriska förändringar har gjort att även om flera intervjuer genomförts i respektive kommun, så kan individerna i SSPF-grupperna ha skiftat. I samtliga gruppintervjuer utom en har deltagare från socialtjänst, skola och polis deltagit. Representanter från fritidssektorn har deltagit i tre av gruppintervjuerna. Individuella intervjuer har hållits med polis (2 st) och SSPF-koordinator. I samtliga fall har skriftligt informerat samtycke inhämtats från respondenterna. Dokument relevanta för utvecklingen av SSPF på nationell och lokal nivå har samlats in från de tre kommunerna.

Nedan redovisas i tabellform den empiri som samlats in. Tabellen visar också vilken empiri som används för analys på respektive nivå. I bilaga 1 finns en än mer utförlig beskrivning av vilket empiriskt material som samlats in samt delmoment och förfarande. 
Tabell 2. Översikt av empiriskt material som analyseras i studien

\begin{tabular}{|l|l|l|}
\hline Policy/struktur & Organisation/ profession & Praktik/familj \\
\hline $\begin{array}{l}\text { 8 styrdokument på } \\
\text { nationell och lokal nivå - } \\
\text { studie (preciseras i } \\
\text { tabell 3). }\end{array}$ & $\begin{array}{l}\text { 8 gruppintervjuer med } \\
\text { samverkansparter - totalt 25 } \\
\text { personer }\end{array}$ & $\begin{array}{l}\text { 8 gruppintervjuer med } \\
\text { samverkansparter - totalt 25 } \\
\text { personer }\end{array}$ \\
\hline & $\begin{array}{l}3 \text { Individuella intervjuer med } \\
\text { samverkansparter }\end{array}$ & $\begin{array}{l}\text { Enkät till 30 SSPF-kommuner } \\
-10 \text { svar }\end{array}$ \\
\hline & $\begin{array}{l}\text { Enkät till 30 SSPF-kommuner - } \\
10 \text { svar }\end{array}$ & $\begin{array}{l}\text { Observationer vid 7 SSPF- } \\
\text { möten, varav 4 } \\
\text { styrgruppsmöten och 3 } \\
\text { arbetsgruppsmöten }\end{array}$ \\
\hline & $\begin{array}{l}\text { Observationer vid 7 SSPF - } \\
\text { möten (4 styrgruppsmöten och } \\
3 \text { arbetsgruppsmöten) }\end{array}$ & $\mid$ \\
\hline
\end{tabular}

Observationer har genomförts vid fyra SSPF-möten varav två möten på chefsnivå och två på verksamhetsnivå. Det senare betyder möten där också den unge och vårdnadshavare deltar tillsammans med representanter för de olika samverkansparterna.

De 10 enkätsvar av 30 möjliga, som blev resultatet av enkäten används inte i kvantitativt syfte med anledning av den låga svarsfrekvensen, däremot används enkätens fritextsvar, då de är relativt innehållsrika.

\section{Genomförande av materialinsamling}

För att så tydligt som möjligt kunna besvara mina frågor, har jag arbetat med så kallad triangulering, vilket innebär att flera olika metoder och källor används och vägs samman för resultatet (Andreasson \& AspOnsjö 2009).

Vägen under materialinsamlingen har krävt ett flexibelt förhållningssätt. Ambitionen när studien startade var att huvudfokus och utgångspunkt skulle vara familjens perspektiv på SSPF. Tanken vid start var att följa ett 
antal ungdomar över tid och göra 2-3 intervjuer med varje ungdom och deras föräldrar under tiden från att de blev erbjudna SSPF fram till något år efter. Detta har inte varit möjligt, då det varit svårt att få tillgång till respondenter bland ungdomar och föräldrar, varför förändringar skett varefter studien framskridit. Under rubriken metodsvårigheter beskrivs detta mer ingående.

Ett verktyg i rekryteringen av familjer, var en enkät som gick ut till 30 SSPF-koordinatorer runt om i landet (bilaga 2). Frågorna handlade om modellen och bestod till största delen av fritextfrågor. 10 svar inkom trots upprepade påminnelser. Fritextsvaren i enkäten används som källmaterial i studien, men då som komplement till övrig empiri.

Intervjuer

För att fånga de yrkesverksammas bild av SSPF-arbetet har gruppintervjuer av fokusgruppstyp använts i undersökningen, men också enskilda intervjuer med nyckelpersoner. Grupperna har bestått av samverkansparter i SSPF-grupper i de tre kommunerna, det vill säga personer som träffas regelbundet i dessa sammanhang. En tolkning av fokusgrupper är att de ska bestå av personer som vanligtvis inte ses och delar vardag (Wibeck 2000). Ur den aspekten kan man inte kalla intervjuerna för fokusgruppsintervjuer, men tillvägagångssättet som använts i studien är detsamma. Fokusgruppsintervjun går ut på att gruppdeltagarna diskuterar teman ledda av en moderator som i detta fall varit jag. Moderatorn ser till att fokus hålls och lägger fram de teman som ska diskuteras, men har annars en ganska passiv roll. Målet är inte att konsensus i gruppen ska uppnås, utan att de olika gruppmedlemmarnas tankar och åsikter ska bli tydliga (Kvale \& Brinkman 2009).

I såväl grupp- som $\mathrm{i}$ individuella intervjuer har jag haft en ambition att tillämpa det som Holstein \& Gubrium (1995) kallar den aktiva intervjun. Den aktiva intervjun har mer formen av ett samtal, en konversation, där den intervjuade personen och den intervjuande forskaren tillsammans skapar mening. Intervjun vinner på att intervjuaren är insatt $\mathrm{i}$ ämnet och de förhållanden som råder. Därför kan också den så kallade förförståelsen ha en positiv inverkan på intervjun både vad gäller att förstå intervjupersonens perspektiv men också för att delad kunskap och 
delade perspektiv ger bättre förutsättningar för samproduktionen av kunskap under intervjun (ibid). Jag menar att detta sätt att arbeta med intervjuer passat mig som person och forskare.

Jag har använt intervjuguider i semistrukturerad form i både intervjuer i grupp och enskilt (bilaga 4 och 5), i detta fall innebär det att ett antal teman har förberetts av mig och vägleder intervjun, men i övrigt har samtalet flutit ganska fritt. Gruppintervjuerna med samverkansparterna har genomförts i kommunala lokaler, vanligtvis konferensrum eller liknande. Enskilda intervjuer med samverkansparter har ägt rum på deras respektive arbetsplats. Intervjuerna med samverkansparterna varade mellan 45 minuter och 75 minuter. Samtliga intervjuer spelades in i sin helhet.

\section{Dokument}

De dokument som studerats är de som styr och vägleder arbetet med SSPF i kommunerna - såväl nationella som lokala dokument har granskats. Det handlar om strategidokument, riktlinjer, överenskommelser och handlingsplaner för brottspreventiv samverkan, samt handlingsplaner för SSPF-arbetet. Anledningen till att just dessa dokument valts ut till analysen är att de bidrar till förståelsen för hur SSPF-arbetet och det lokala samverkansarbetet mellan kommun och polis samt växt fram, men också till bakgrunden till detta på nationell nivå.

Tabell 3: Översikt över dokument som ingår i studien

\begin{tabular}{|l|}
\hline \multicolumn{1}{|c|}{ Nationella dokument } \\
\hline $\begin{array}{l}\text { Strategi för samverkan - kring barn som far illa eller riskerar att fara illa } \\
\text { (Socialstyrelsen } \mathrm{m} \text { fl 2007) } \\
\text { Polis och kommun - för en lokalt förankrad polisverksamhet i hela landet (RPS } \\
\text { 2008) }\end{array}$ \\
\hline
\end{tabular}




\begin{tabular}{|l|c|c|}
\hline Storstad & Lokala överenskommelser & $\begin{array}{c}\text { SSPF- } \\
\text { dokument }\end{array}$ \\
\hline Mellanstad & $\begin{array}{l}\text { Överenskommelse om } \\
\text { samverkan (2012) }\end{array}$ & $\begin{array}{c}\text { SSPF. Skola- } \\
\text { socialtjänst-polis- } \\
\text { fritid (PPT) }\end{array}$ \\
\hline Lillestad & $\begin{array}{l}\text { Samverkansöverenskommelse } \\
\text { mellan polismyndigheten i Y län } \\
\text { och Mellanstad kommun (2013) } \\
\text { Arbetsbok. Barn och unga 10-20 } \\
\text { år i risk att utveckla eller som har } \\
\text { ett kriminellt beteende och/eller } \\
\text { missbruk (2013) }\end{array}$ & $\begin{array}{c}\text { Skola, socialkontor, } \\
\text { polis \& fritid i } \\
\text { samarbete. SSPF } \\
\text { (folder 2014) }\end{array}$ \\
\cline { 2 - 3 } & $\begin{array}{l}\text { Samverkansöverenskommelse } \\
\text { mellan polismyndigheten i X län } \\
\text { och Lillestad kommun (2014) }\end{array}$ & $\begin{array}{c}\text { Samverkan } \\
\text { socialtjänst, skola, } \\
\text { polis och fritid- } \\
\text { handlingsplan } \\
\text { (2013) }\end{array}$ \\
& $\begin{array}{l}\text { Bilaga till } \\
\text { samverkansöverenskommelse. } \\
\text { Handlingsplan (2014) }\end{array}$ & \\
\hline
\end{tabular}

\section{Övrigt material}

Utöver ovanstående har sju observationer vid SSPF-möten i en av de studerade kommunerna genomförts och anteckningar förts.

Observationerna har inspirerats av etnografiskt fältarbete där "forskaren skriver ned vad hon ser, hör och är med om” (Ehn \& Löfgren 1996, s.115). De möten som observerats har varit på såväl styrgrupps- som arbetsgruppsnivå, vid de sistnämnda har ungdom och vårdnadshavare deltagit. Mötesdeltagarna har tillfrågats om samtycke till mitt deltagande. Min roll har varit iakttagarens och jag har suttit vid sidan av mötesdeltagarna. Fokus för anteckningarna har varit talutrymme och upplägg samt hur det talas om den unge och vad som kan göras.

Noteringar har gjorts gällande hur stor del av dessa möten som upptas av problembeskrivning respektive positiva beskrivningar av den unge samt när och hur förslag till lösningar diskuteras utifrån de olika parternas bidrag till den gemensamma planen för den unge.

Fritextsvaren från den enkät som tidigare beskrivits är ytterligare ett empiriskt material.

Jag övergår nu till beskrivning av hur studiens data har bearbetats och analyserats. 


\section{Bearbetning och analys}

Såväl fokusgruppsintervjuerna som de individuella intervjuerna har transkriberats i sin helhet. Skratt, långa pauser och liknande noteras och de citat som används i resultatredovisningen är trogna utskrifterna frånsett ett par förtydligande grammatiska korrigeringar för att underlätta förståelsen. Vid utelämnande av ord eller meningar i löpande citat markeras detta med /.../. Utelämnande i början av en mening markeras med .... Jag har läst igenom utskrifterna av intervjuerna flera gånger, kodning eller kategorisering har gjorts och olika grundteman har växt fram. Även om förhållningssättet gentemot materialet varit öppet, så har studiens frågeställningar delvis påverkat hur materialet analyseras och tolkas.

Det empiriska materialet har hanterats så att det delats upp och behandlats på två sätt; de beskrivna styrdokumenten har genomgått en textanalys där ett teoretiskt raster använts som verktyg för att analysera texterna. Detta raster är en typologi över brottspreventiva modeller av Ingrid Sahlin, återgiven i teorikapitlet samt beskriven i inledningskapitlet. Dokumenten har lästs noggrant och en analys som påminner om innehållsanalys har genomförts av detta material. Det betyder i detta fall att efter de första förutsättningslösa genomläsningarna, har utifrån kategorierna i Sahlins typologi noteringar gjorts i kanten på dokumenten där de olika begreppen i typologin är representerade. Dessa har därefter sammanställts och granskats flera gånger för att säkerställa relevansen. Beslutet att använda Sahlins typologi som verktyg kom ganska sent i processen, liksom beslutet att $i$ en andra tolkningsprocess använda nyintitutionella begrepp.

Övrig empiri har analyserats genom det som Patton (2002) kallar tematisk analys. Genom upprepad läsning av det empiriska materialet växer mönster av "igenkännande" fram. Där har jag letat bland annat efter repetitioner, likheter och skillnader och kategorier (Bryman 2002, s529). Särskilt intressant i mitt material är att se om särskilda termer, specifika för SSPF dyker upp för att därigenom fånga det unika med denna specifika modell (Patton 2002).

Skillnaden mellan innehållsanalys och tematisk analys i kvalitativ forskning är främst att kontexten blir viktig i tematisk analys och att 
innehållsanalysen på ett sätt är mer kvantitativ, då frekvens av återkommande data blir viktigt (Vaismoradi et al 2013). En tematisk analys är flexibel och användbar och inte fast knuten till någon epistemologisk ansats, även om arbetssättet påminner om exempelvis Grounded theory, dock utan avsikten att generera teori (Braun \& Clarke 2008). Syftet har varit att hitta mönster/teman i data på en detaljerad nivå. Koder och teman har växt fram utifrån materialet genom identifiering och analys och inte varit givna i förväg (Holm \& Krohn Solvang 2009, Vaismoradi m fl. 2013, Braun \& Clarke 2008)). Data har kategoriseras och organiserats i centrala huvudteman och underteman, (Bryman 2002, Braun \& Clarke 2006). Analysfasen av mitt material började egentligen redan då intervjuerna genomfördes och fortsatte vid utskrift och noggrann upprepad genomläsning och blev på ett djupare plan tolkningen av materialet (Silverman 2005, Kvale \& Brinkman 2009). Huruvida ett tema konsekvent ska finnas i varje intervju avgörs i den unika studien. De teman jag identifierat har varit återkommande $i$ materialet, dock inte nödvändigtvis i varje utskrift, vilket är idealt, men till skillnad från en kvantitativ innehållsanalys, är mening och förståelse det viktiga i en tematisk analys (Braun \& Clarke 2006).

Det empiriska materialet i min studie har alltså bearbetats i flera omgångar. Vid genomläsning har anteckningar gjorts i marginalen, dessa har blivit till koder som sedan systematiseras i teman ${ }^{23}$. Dessa har tolkats både var för sig och i förhållande till varandra med hjälp av de teoretiska verktyg som växt fram under resans gång. Till en början har jag arbetat till stor del induktivt med öppna kodningar, men vartefter mönster framträtt och det blivit mer tydligt vad jag letar efter, har processen blivit mer deduktiv. De teman respektive underteman som växt fram ur materialet är bland annat:

\footnotetext{
${ }^{23}$ Det finns dataprogram som är användbara vid systematisering av data, jag har dock gjort detta manuellt.
} 
Tabell 4: Teman och underteman ur det empiriska materialet

\begin{tabular}{|c|c|}
\hline Huvudtema & Underteman \\
\hline Alliansskapande & $\begin{array}{l}\text { - Den professionella alliansen } \\
\text { - Alliansen mellan samhälle och } \\
\text { familj }\end{array}$ \\
\hline Sekretess & $\begin{array}{ll}\text { - } & \text { Sekretessen som hinder } \\
\text { - } & \text { Nyckeln till framgång }\end{array}$ \\
\hline Aktörer/roller & $\begin{array}{ll}\text { - } & \text { Spänning stöd/kontroll } \\
\text { - } & \text { Likriktning/rollförvirring }\end{array}$ \\
\hline
\end{tabular}

\section{Metodsvårigheter}

Studiens design och ambition var från början att i förgrunden ha de enskilda ungdomarna och deras föräldrar och de perspektiv dessa har på SSPF-modellen. Det har visat sig vara mycket svårt att få tillgång till dessa ungdomar och deras familjer, då jag varit beroende av att koordinator eller annan person i SSPF-gruppen framfört förfrågan om samtycke till att delta i studien. De tre kommunerna som ingår i studien har bearbetats kontinuerligt med förfrågningar om aktuella familjer.

Frågan om förmedling av kontakt med familjer har också gått ut till totalt 30 kommuner/stadsdelar via den enkät som beskrivits ovan, endast de tre undersökningskommunerna har sagt sig ha möjlighet till detta. Vad denna svårighet kan bero på är svårt att säga, men troligen handlar det till en del om så kallad "gate keeping"(Sallnäs m fl. 2010), det vill säga att de professionella håller tillbaka och gör en förhandsbedömning om att det inte är lämpligt att göra en forskningsintervju med den unge. Under resans gång har därför studien svängt till att beakta flera andra perspektiv vilket gör att den enskilde ungdomen och föräldern inte kommer i fokus i uppsatsen. I stället ges mer utrymme till hur de professionella upplever SSPF ur olika aspekter samt hur dessa samspelar med familj och ungdom. Detta behöver dock inte vara en begränsning, då forskningsproblemet visat sig vara mer komplext än vid en första anblick och de olika perspektiven kan komplettera varandra till en helhetsbild och även sätta problemet i ett större sammanhang.

En annan och inte obetydlig svårighet i studien är att empirin kan tyckas vara omfattande, flera källor och metoder har använts och det gäller att inom ramen för studien låta dessa komplettera och kanske utmana varandra för att bidra till helheten. 


\section{Etiska överväganden}

En intervjusituation är en interaktiv process, ett möte mellan forskare och informant, där olika etiska aspekter blir viktiga, särskilt i mötet med socialt utsatta människor. Dessa möten kan vara maktfulla, men också leda till ny kunskap som kan leda till bättre förhållanden för människor i social utsatthet (Andersson \& Swärd 2008). Själva intervjusituationen kan också vara pressande för informanten på så sätt att man kan komma att behöva motivera sina handlingar som kanske inte alltid är genomtänkta och rationella (Sohlberg \& Sohlberg 2009).

En mängd etiska överväganden bör göras under hela forskningsprocessen (Silverman 2011) och självklart bör man noga fundera på detta i samband med själva intervjun. Det ligger i forskarens makt att kategorisera, tolka och benämna människor, grupper och fenomen och själva intervjusituationen kan också innebära en maktposition för forskaren (Andersson \& Swärd 2008). Jag har också en yrkesmässig relation till några av samverkansparterna som jag intervjuat. Dessa är inte kollegor i det dagliga arbetet, däremot har jag träffat dem i yrkesmässiga sammanhang. Det kan därför vara svårt att vara helt säker på att detta inte påverkat intervjuerna, då vi inte är helt okända för varandra. Här har jag varit noga med att markera min roll som forskare och inte gå in i några yrkesmässiga resonemang med informanterna.

Jag har beaktat de fyra forskningsetiska principerna; informationskravet, samtyckeskravet, konfidentialitetskravet och nyttjandekravet. Studien har föregåtts av en etikprövning i den regionala etikprövningsnämnden (Linköpings universitet Dnr 2012/159-31) enligt lagen om etikprövning av forskning (2003:460). Samtliga informanter har lämnat skriftligt informerat samtycke till att delta i studien (bilaga 3). Jag har valt att hålla de undersökta kommunerna anonyma, trots att inga ungdomar deltar i studien. Då detta troligtvis kommer att ske framöver, vill jag behålla kommunerna anonyma för att minska risken för identifikation. Detta gör också att integriteten hos de intervjuade professionella ökar.

\section{Studiens giltighet}

Denna studie kan endast göra anspråk på att uttolka de källor som ligger till grund för specifikt denna och kan därmed inte generaliseras till allt 
SSPF-arbete i Sverige. Dock bör resultaten leda till en ökad förståelse av det undersökta området brottspreventiv samverkan på individnivå (Kvale \& Brinkman 2009).

Gällande studiens reliabilitet, det vill säga möjligheten till replikering, så kan det vara svårt att exakt replikera studien, bland annat då intervjukontext och annat kan vara svårt att återskapa. Istället är det viktigt att göra hela forskningsprocessen och varje steg i den, transparent (Bryman 2002) vilket jag försökt att göra genom att beskriva varje moment i processen. Genom tillämpandet av triangulering har också den inre validiteten stärkts (Andreasson \& Asp-Onsjö 2009). De tolkningar som görs ska hålla för granskning, här har flera textseminarier hållits under resans gång för att säkra den kommunikativa validiteten (Kvale \& Brinkman 2009). 


\section{Samverkan växer fram}

I följande tre kapitel redovisas de empiriska resultaten. Kapitel 7 och 8 har fokus på SSPF som arbetsform, på samverkan och interaktion mellan parterna inklusive familjen, förutsättningar för att arbeta med SSPFmodellen samt hur arbetet upplevs av aktörerna.

Detta kapitel, som utifrån figur 1 har fokus på policy och struktur, innehåller en presentation och analys av de dokument som varit vägledande och styrande i Sverige och i de undersökta kommunerna i framväxten av brottspreventiva samverkansmodeller såsom SSPF. De studerade dokumenten omfattar såväl nationell som lokal nivå och hjälper till i förståelsen av denna framväxt. De nationella dokument som studerats har haft stor betydelse för utvecklingen mot en alltmer intensifierad samverkan mellan polis och kommun det senaste decenniet. De lokala dokumenten är överenskommelser om brottspreventiv samverkan mellan kommun och polis som de tre undersökningskommunerna slutit. Ytterligare lokala dokument som studeras är handlingsplaner och specifika styrdokument för SSPF, där sådana funnits. Polisen är, som tidigare beskrivits, initiativtagare till en stor del av arbetet, vilket blir tydligt i studien av dokumenten.

Det är inte bara dokumenten som sådana som är intressanta för studiens syfte, utan också hur det går till när dessa ska implementeras i praktiken och i lokala samverkanskontexter. Här kommer nyinstitutionell teoribildning, där det talas om en idés resa och översättning och dess begrepp till hjälp. I någon kontext skapas en idé, såsom idén om brottspreventiv samverkan runt enskilda ungdomar. I detta fall skapas idén på nationell nivå, förpackas där och reser ut till en regional och/eller lokal nivå där den packas upp och översätts (Johansson, R. 2006, Linde \& Svensson 2013, Czarniawska \& Joerges 1996, Ahlgren $2014)^{24}$. I detta kapitel analyseras denna resa för idén om brottspreventiv samverkan runt enskilda ungdomar, där beteckningen brottspreventiv talar om att polisen har en central roll, vilket är specifikt för denna typ av samverkan runt unga individer. Tre kommuner ingår i studien, en

\footnotetext{
${ }^{24}$ För tydligare beskrivning, se kapitel 4 .
} 
stadsdel i en storstadskommun, denna kommun kallas Storstad och stadsdelen för Storstadsdel; en större kommun, som här kallas Mellanstad och till sist en mindre kommun, här kallad Lillestad. Här ska påpekas att SSPF som arbetssätt introducerades i Malmö och Göteborg $^{25}$ något innan de studerade dokumenten publicerades. Därefter har SSPF-arbetet vävts in i de lokala överenskommelserna mellan polis och kommuner.

Som verktyg i analysen av dokumenten har Ingrid Sahlins typologi för preventionsmodeller (Sahlin 2000, s. 86-112), beskriven i kapitel 4, använts. Här problematiseras brottspreventiva åtgärder, vad som motiverar dem och vilket syfte de har. Är det exempelvis samhällets ordning eller individens välfärd som motiverar insatsen? Resonemanget kan knytas samman med samhällsutvecklingen i stort och ge en bild av vad som motiverar dagens brottsförebyggande samverkan. Detta, tillsammans med begrepp från nyinstitutionell teoribildning bör ge ökad förståelse för processen med ett arbetssätt som SSPF.

\section{Idéförpackning på nationell nivå - resan startar}

Idén om brottspreventiv samverkan på individnivå, där Polisen är aktör och dessutom har en central roll, aktualiserades under 2000-talet ${ }^{26}$.

Brottspreventiv samverkan som sådan, på mer generell- eller gruppnivå, har mycket längre historia än så. Denna studie fokuserar på brottspreventiv samverkan runt enskilda unga individer, just denna idé är som beskrivits av senare slag.

Det första dokumentet är ett policydokument och en metodskrift om samverkan, vilken fick betydelse för det brottspreventiva samverkansarbetet när den publicerades år 2007. Dokumentet togs på regeringens uppdrag fram av de myndigheter på nationell nivå som styr

\footnotetext{
${ }^{25}$ Detta kan även gälla någon ytterligare kommun i Sverige, något som varit svårt att få fram.

${ }^{26}$ Som tidigare beskrivits finns dokument gällande individriktad samverkan från 1950-, 60och 70-tal som också talar om samarbete mellan polis och kommun på individnivå. Sett till de senaste tre-fyra decennierna är dock polisens roll i individriktad samverkan ny och skiljer sig från tidigare former.
} 
socialtjänst, polis och skola- Socialstyrelsen, Rikspolisstyrelsen och dåvarande Myndigheten för skolutveckling. Dokumentet skulle vara ett stöd i den skärpta lagstiftningen(prop 2002/03:53) och har varit vägledande i den fortsatta utvecklingen av samverkan på individnivå (Skolverket 2009; Danermark m fl 2009). I detta inbegrips således också brottspreventiv samverkan, då polisens roll fastslås i dokumentet.

\section{Gemensam metodskrift}

När polis, skola och socialtjänst på nationell nivå år 2007 gick samman om en metodskrift: Strategi för samverkan - kering barn som far illa eller riskerar att fara illa, rörande det nödvändiga samarbetet runt dessa barn, utgjorde det starten på en nyare form av samverkan som skulle implementeras på lokal nivå. Tre myndigheter gick här samman för att mer kraftfullt kunna samarbeta (Socialstyrelsen, Rikspolisstyrelsen \& Myndigheten för skolutveckling 2007). Med nyinstitutionell terminologi var det här idén förpackades och startade sin resa. Samverkan runt unga individer var ingalunda nytt vid tidpunkten, inte heller samverkan där polisen hade en viktig roll - däremot blev polisens roll nu tydlig och självklar på ett nytt sätt även i den sociala brottspreventionen på individnivå. Skriften omfattade både barn som far illa på grund av omsorgsbrist och utsatthet för miljöer med missbruk och våld och:

\section{barn och ungdomar med ett socialt nedbrytande beteende, såsom missbruk, kriminalitet eller annat självdestruktivt beteende (Socialstyrelsen $\mathrm{m}$ fl. 2007 s.11)}

Citatet ovan förtydligar målgruppen för arbetsformer som SSPF. Riskoch skyddsparadigmet - det vill säga identifikation av riskfaktorer och skyddsfaktorer som kan komma att påverka den unges utveckling - är tydligt uttalat i detta dokument och har fått starkt fäste i olika förebyggande program och dokument, exempelvis handlingsplaner för SSPF. Betoningen ligger mer på riskfaktorer och hur dessa ska identifieras än på vilka skyddsfaktorer som ska förstärkas. Tidiga upptäckter av ovan beskrivna barn och unga är centralt i metodskriften och samhällets gemensamma ansvar för detta kan inte misstolkas, då man återkommande hänvisar till den lagstadgade skyldigheten för 
berörda myndigheter att samverka i frågor som rör barn som far illa eller riskerar att fara illa. Identifikation av riskfaktorer hos barn och tidiga upptäckter av normbrytande beteenden är således återkommande i diskursen för detta område, såväl i dokument som i diskussionen, vilket citatet nedan illustrerar:

Utgångspunkten för att bedöma vilka barn och ungdomar som ingår $i$ målgruppen är kunskap om risk-och skyddsfaktorer. Dessa finns hos barnet självt, i familjen, $i$ närmiljön och på samhällsnivå (ibid s. 11).

Socialtjänstens särskilda ansvar att verka för samverkan utifrån det yttersta ansvaret för dessa barn och unga betonas också i skriften (ibid s. 13). De viktiga förutsättningar för samverkan som lyfts fram i skriften är, med hänvisning till aktuell forskning: styrning, struktur och samsyn. I dokumentet betonas att barnets behov och inte organisationens ska vara i centrum i samverkan. I ett stycke behandlas etiska dilemman som kan uppkomma i samverkan kring dessa barn och vikten av att beakta delaktighet från dem det gäller:

Det finns alltid en risk att berörda genom samverkan
upplever att kontrollen ökar. Därför är det av största vikt
att samverkan inkluderar mesta möjliga delaktighet och
öppenhet samt att de samverkande verksamheterna är
lyhörda när det gäller formerna för samverkan.
/.../Samverkan mellan myndigheter får inte leda till att
man kringgår sekretesslagstiftningen (s. 37).

Detta är särskilt relevant när det kommer till individriktad samverkan. I citatet betonas vikten av att upprätthålla sekretessen här, $\mathrm{i}$ fallet med SSPF och liknande samverkansformer hanteras detta genom det tidigare beskrivna samtycket till informationsutbyte mellan myndigheter.

Vid granskning av dokumentet finner vi i metodskriften tal om socialisation av individen ökad möjlighet till kontroll från samhällets sida genom tidigare upptäckter av unga i risk. Framför allt framträder viljan till effektivisering av institutioner, det vill säga vikten av att genom 
samverkan nå snabbare och bättre resultat runt den unge. Tre av Sahlins fyra fält i typologin är alltså representerade i metodskriften (Sahlin 2000, se figur 2).

Tal om strukturförändring på samhällsnivå (ibid) lyser med sin frånvaro i dokumentet. Strukturförändringsmodellen är den som bäst överensstämmer med det som uttrycktes i the Nordic model for crime prevention(Brå \& Nordiska rådet 2000) ${ }^{27}$, det vill säga att grunden för brottsprevention ligger i människors möjlighet till bostad, utbildning och drägliga ekonomiska förhållanden samt ett jämlikt samhälle. I metodskriften Strategi för samverkan - kring barn som far illa eller riskerar att fara illa förekommer inte alls resonemang på strukturell nivå. Denna brottsförebyggande diskurs hör enligt flera forskare mer hemma i 1970och tidiga 80-talet, då resonemangen handlade om att i ett inkluderande samhälle blir brottspreventionen mer en positiv bieffekt (Sahlin 2000, Wahlgren 2014).

Den gemensamma metodskriften var långt ifrån det första dokument som tagits fram gällande samverkan mellan polis och kommun (Edvall Malm 2012), men det fick stort genomslag och polisen beslutade, genom Rikspolisstyrelsen - RPS - att omsätta detta och initiera samarbete på lokal nivå. RPS tog initiativ till skrivna överenskommelser där polis, socialtjänst och skola och eventuellt andra aktörer i varje kommun i Sverige gemensamt skulle arbeta brottsförebyggande på ett mer intensivt sätt än tidigare. Detta skrevs fram i en nationell handlingsplan från Rikspolisstyrelsen, vilket är nästa dokument som behandlas.

Nationell handlingsplan från Rikspolisstyrelsen

År 2008 - året efter att ovanstående metodskrift eller strategidokument kom, tog Rikspolisstyrelsen fram en handlingsplan som gick ut till samtliga polisdistrikt i Sverige: Polis och kommun - för en lokalt förankrad polisverksambet $i$ hela landet (RPS 2008). Här packas idén om

\footnotetext{
${ }^{27}$ The Nordic model beskrevs i kapitel 2.
} 
brottspreventiv samverkan upp på regional nivå ${ }^{28}$, tolkas och förpackas om för att sändas ut till den lokala nivån, det vill säga samtliga kommuner runt om i Sverige och den lokala praktiken. Med detta menas att handlingsplanen skickas till de regionala polismyndigheterna, som i sin tur ser till att den kommer vidare till de lokala polisområdena. Dessa i sin tur uppvaktar kommunerna för gemensamma överenskommelser.

Den nationella handlingsplanen gick ut på både att effektivisera samverkan för ökad trygghet och minskad brottslighet och att öka förståelsen för - och den lokala förankringen av - polisens arbete (Rikspolisstyrelsen 2008, Edvall Malm 2012). Detta skulle göras genom att samtliga polismyndigheter tillsammans med landets kommuner skulle skriva strategiska samverkansöverenskommelser som skulle grundas i

underrättelseinhämtning hos polisen och kommunen

och

gemensam lägesbild av lokala problem (RPS 2008 s.6)

RPS hänvisar i dokumentet till de lokala brottsförebyggande råden som viktiga forum för arbetet och att fler ska ta ansvar för brottsförebyggande insatser:

\section{Meningen är att bredda det operativa genomförandet (av brottsförebyggande insatser) till att så många samhällsaktörer som möjligt samverkar samt att klargöra de olika aktörernas ansvar och roller i arbetet (ibid s.7)}

Citatet visar på strävan efter det utökade nätet -net-widening- som exempelvis Stanley Cohen (1985) talar om.

I dokumentet är inte barn och ungdomar och individriktat arbete $i$ särskilt fokus, men i de områden där samarbete och även insatser från polis respektive kommun föreslås, såsom narkotika och utomhusvåld, är många insatser riktade till barn och unga. I bakgrundsavsnittet diskuteras omvärldsfaktorer och samhällsförändring. Man talar om globalisering

\footnotetext{
${ }^{28}$ Fram till år 2015 var Polisen organiserad i regionala polismyndigheter. Från 1 januari 2015 finns en enda nationell Polismyndighet.
} 
och individualisering och även den tekniska utvecklingen som förklaringar till dagens brottslighet. Vidare menar man att den naturliga sociala kontrollen inte fungerar som förr:

Den sociala kontrollen i samhället har därtill förändrats och försvagats genom urbanisering och nya livsmönster (ibid s.4).

Resonemanget skulle eventuellt som förklaring sägas höra till Sahlins strukturförändringsmodell, men då det är en förklaring mer än en föreslagen insats stannar det där och istället faller det inom ramen för 2000-talets diskurs om sveket mot samhället (Wahlgren 2014, se kap 2). Inslagen som ligger i linje med kontrollmodell och effektivisering av institutioner framträder också i dokumentet. Återigen handlar det om att bredda och vidga nätet för kontroll i samhället och det handlar om att genom samverkan - här i formaliserad form - effektivisera arbetet, $\mathrm{i}$ detta fall polisens arbete. Rikspolisstyrelsen dikterar här i stort sett hur avtalen mellan kommun och polis ska se ut samt föreslår även vilka insatser kommunen kan tänkas göra inom de olika problemområdena. I handlingsplanen är signalen tydlig till polismyndigheterna: sätt igång och samarbeta med kommunerna! Även om inte individriktat arbete nämns explicit i dokumentet kom detta dokument tillsammans med metodskriften ovan att inspirera kommuner att tillsammans med polisen intensifiera arbetet även på individnivå, varför dokumentet är relevant $\mathrm{i}$ sammanhanget. Så är fallet i de kommuner jag studerat.

\section{Översättning i den lokala kontexten}

I det följande fokuseras dokument som rör samverkansarbetet i de tre undersökta kommunerna, med start i de lokala samverkansöverenskommelserna mellan polis och kommun.

Lokala överenskommelser mellan polis och kommun

När idén om brottspreventiv samverkan på individnivå färdats ut i kommunerna, packas den upp och översätts och tillämpas med anpassning till lokala omständigheter och de aktörer och institutioner som verkar och samverkar där - i regel skola, socialtjänst, polis och fritidssektor. 
Rikspolisstyrelsens handlingsplan år 2008 ledde i sin tur till att samverkansöverenskommelser mellan polismyndigheterna och de flesta av landets kommuner upprättades. I skrivande stund har 85 procent av landets kommuner samverkansöverenskommelser med polismyndigheterna (www.bra.se). Samverkansdokumenten har hög dignitet i kommunerna och hos Polisen och de undertecknas av kommunstyrelseordförande och länspolismästare för att betona detta.

Polisen var på de flesta håll initiativtagare till arbetet med överenskommelserna och var också de som initierade SSPF-arbetet i de i studien undersökta kommunerna. I överenskommelserna har man förtydligat genom mål vilka områden som man särskilt vill satsa på, dessa mål är ofta mätbara. Exempelvis återkommer minskad brottslighet, minskad alkoholkonsumtion och liknande i dokumenten, ibland preciserade med angivelse om hur stor andel exempelvis ungdomskriminaliteten i kommunen ska minska. Barn och unga ges särskild prioritet och tidig identifikation och upptäckt återkommer i dessa dokument:

Särskild prioritet ska ges tidig upptäckt av barn och ungdomar $i$ behov av insatser för att motverka utanförskap och normbrytande beteende såsom missbruk, kriminalitet och kontakt med organiserad brottslighet och kriminella gäng (Överenskommelse Mellanstad 2013)

Att förebygga att ungdomar använder droger och tidigt upptäcka ungdomar som uppvisar riskbeteende är en viktig insats för individen och samhället (Överenskommelse Storstadsdel 2012)

Överenskommelserna i sig är relativt kortfattade men de kan också omfatta en handlingsplan där operationaliseringen av arbetet framgår, alternativt finns en utarbetad bilaga för detta. I de mer konkreta handlingsplanerna som hör till överenskommelserna överväger de situationella brottsförebyggande insatserna, det vill säga de åtgärder som handlar om att minska tillfällen till brott. 
I de lokala överenskommelserna återkommer huvudsakligen kontrollmodellen och effektivisering av institutioner, men även socialisationsmodellen representeras då man vill stoppa unga individers väg mot ett ogynnsamt liv och påverka individers beteende för att "gynna samhällets ordning" (Sahlin 2000, s.97). Ett sätt att göra detta är att stärka andra vuxna som finns runt ungdomarna, såväl föräldrar som exempelvis skolpersonal. Exempelvis nämns som åtgärder man vill vidta:

arbete kring ungas attityder (till droger) och stödja och stärka ungdomar (Överenskommelse Lillestad 2013)

stödja föräldrar så att de lättare ska kunna föra samtal om bland annat ANDT-frågor med sina ungdomar (Överenskommelse Storstadsdel 2012)

I en av handlingsplanerna nämns att kommunen ska verka för:

fritidsgårdar och andra mötesplatser (Överenskommelse Lillestad 2013)

Detta är den enda insats i de lokala dokumenten som kan tolkas in i modellen för förändring av struktur och miljö, då det handlar om att mötesplatser för ungdomar kan vara brottsförebyggande. I övrigt fokuseras mycket på individriktade insatser och tidig upptäckt.

Även Lillestads handlingsplan innehåller individfokuserade insatser, förutom SSPF vill man arbeta gemensamt med så kallade bekymringssamtal ${ }^{29}$ och medling. Dessa insatser ryms samtliga inom kontrollmodellen och speglar återigen ett slags ett slags net-widening (Cohen 1985, Kelly 2012), hur alltfler i samhället engageras i att upptäcka och kontrollera individen.

\footnotetext{
${ }^{29}$ Bekymringssamtal är en metod som kommer från Norge, där polis och socialtjänst i ett tidigt skede av negativ utveckling håller ett samtal med den unge och dess vårdnadshavare för att betona allvaret.
} 
I handlingsplanerna beskrivs återkommande vad man vill göra eller verka för, dock saknas ofta beskrivningar om bur detta ska gå till eller vem som ansvarar för vad.

\section{Dokument om SSPF- samverkan}

I samverkansöverenskommelserna mellan polis och kommun återkommer fokus på ungdomar och ungdomskriminalitet. I undersökningskommunerna har man sedan gått vidare med att precisera detta i dokument som handlar just om SSPF eller där SSPF finns med som en del. En lokal tolkning av modellen sker, där lokala förhållanden och aktörer påverkar översättning och tillämpning (Ahlgren 2014, Linde \& Svensson 2013).

I de handlingsplaner som finns för det lokala arbetet med SSPF finner vi återigen betoning på tidiga upptäckter av riskbeteende och riskfaktorer. Riskparadigmet blir därigenom återigen tydligt och därmed betoningen på kontroll. Behovet och nyttan av en gemensam bild och samsyn för ett framgångsrikt arbete blir tydlig:

Syftet med projektet (SSPF) är att skapa ett uthålligt samverkansarbete och en samsyn som genererar att barn och unga som far illa eller riskerar att fara illa ska få hjälp i ett tidigt skede av en ogynnsam utveckling (Handlingsplan Lillestad 2013)

SSPF är en aktiv samverkan med polis, grundskola, fritid/kultur och socialtjänsten och syftar till att fånga upp och identifiera ungdomar som far illa eller riskerar att fara illa, t ex genom skolk eller annat riskbeteende (Handlingsplan Storstadsdel 2012)

Citaten ovan visar att viljan till samsyn och gemensam mening är en drivkraft och detta återkommer i det övriga empiriska materialet, vilket beskrivs i kommande kapitel.

Strävan mot snabba insatser genom mobilisering av resurser med målet att bryta ett negativt mönster är centralt i SSPF och återkommer också i dokumenten: 
Genom att samla och samordna resurser kring

barn/unga ska man agera snabbt och skapa

gemensamma lösningar (Handlingsplan Mellanstad

2013)

Förhoppningen är att man genom detta ska göra skillnad och vara mer effektiva än tidigare när det kommer till såväl reaktion som insatser för de ungdomar som blir aktuella för SSPF. Exakt vilka dessa ungdomar är, är osäkert. Målgruppen för arbetet beskrivs på olika sätt i kommunernas dokument vad gäller ålder och problematik, även detta bekräftas av övrig empiri.

I dokumenten som styr och vägleder SSPF framträder det som ligger i linje med Sahlins kontrollmodell genom talet om tidiga upptäckter av negativt beteende, men även genom att man i SSPF använder möjligheten att genom samtycke från föräldrar utbyta information om den unge mellan myndigheterna, vilket blir ett sätt att hantera sekretesslagstiftningen. Vi finner här också exempel på effektivisering av institutioner då man i dokumenten talar om samsyn mellan aktörer och snabba insatser med gemensamma krafter. Ambitionen är återigen socialisation av individen. Diskursen om den förlorade sociala kontrollen som ska hanteras genom tidiga upptäckter och åtgärder samt skärpt kontroll träder fram även i dessa dokument (Sahlin 2000, Wahlgren 2014).

\section{Sammanfattning och reflektion}

Initiativet till samverkansöverenskommelser och handlingsplaner gällande SSPF kommer i många fall från polisen. Det var också Rikspolisstyrelsens handlingsplan från 2008 som på många håll satte fart på samverkansarbetet även på individnivå. Tongivande i de beskrivna dokumenten är med utgångspunkt i Sahlins typografi drag av kontroll samt effektivisering av institutioner, vars överordnade värde är samhällets ordning framför individens välfärd och frihet. På några håll i dokumenten återfinns åtgärder, insatser och resonemang som syftar till socialisering av individen, vilket sätter individen i centrum men med fokus på förändring av individens beteende. Detta kommer in främst i de 
lokala dokumenten, framför allt i de mer konkreta handlingsplanerna för SSPF.

Tal om strukturförändringar eller orsaker till behovet av insatser förekommer endast i Rikspolisstyrelsens dokument (RPS 2008) och då mer som förklarande inslag. Utifrån de dokument som studerats framgår således att resonemang eller förslag om övergripande strukturella förändringar för att minska ungdomars negativa utveckling mot kriminalitet och drogmissbruk sällan tycks föras i dagens brottspreventiva arbete. Detta bekräftas av exempelvis Laura Kellys argumentation, där hon är kritisk mot att den riktade brottspreventionen och riskparadigmet som råder har en tendens att ignorera de strukturella orsakerna till problemen (Kelly 2012). Diskussioner om orsaker till exempelvis ungdomskriminalitet är relativt osynliga i de dokument jag studerat, däremot framträder betoningen av tidiga upptäckter och riskfaktorer.

Ovanstående resonemang tydliggör att utvecklingen av brottsprevention speglar samhällsutvecklingen mot ökad individualisering och nyliberala strömningar. Fokus har flyttats från strukturella och samhälleliga problem till individen och därmed ses lösningen finnas hos individen, även om denne kan få stöd för detta av samhället. Från dokumentet the Nordic model for crime prevention (Brå \& Nordiska rådet 2000) till dagens dokument om brottsprevention kan det diskursiva avståndet i vissa delar vara stort. Det är intressant att dokumentet om the Nordic model publicerades så sent som år 2000, då tankegångarna i det hör hemma i en tidigare diskurs enligt flera skandinaviska forskare (Sahlin 2000, Balvig 2004, Wahlgren 2014 m fl.).

I de studerade dokumenten utgår man från självklarheten med samverkan och dess möjligheter, men det talas inte så mycket om den komplexitet och de svårigheter som kan uppstå när olika institutionella logiker möts i ett gemensamt organisatoriskt fält såsom brottspreventiv samverkan på individnivå - i detta fall SSPF. Bland annat dessa problem kommer nästa kapitel att ta sig an genom resultat och analys av SSPF i praktiken och de organisatoriska förutsättningarna för detta. 


\section{Samspelet mellan organisationer och professionella}

I kapitel 1 beskrevs studiens upplägg med flera fokus gällande SSPF. Kapitel 6 rörde sig inom fokusområdet policy/struktur. I detta kapitel går fokus över till det faktiska arbetet med SSPF, hur det fungerar i praktiken, hur det upplevs av aktörerna och hur förutsättningarna ser ut för att arbetet ska fungera enligt den ambition som finns. Det betyder att organisation/profession är i fokus i det följande. Kapitlets första del är mer beskrivande, därefter följer analys och tolkning gällande samverkansparternas aktörer och dess roller samt de organisatoriska förutsättningar för arbetet som framkommit.

Polisen har som vi sett initierat en stor del av den brottsförebyggande samverkan runt individer, från den nationella nivån till den lokala. Idén om SSPF och liknande samverkansformer runt individer med polisen som central aktör skrivs fram och förpackas i dokument på nationell nivå. Den färdas sedan ut i kommunerna, i den lokala kontexten, där idén tar form - översätts- på lite olika sätt, vilket visas från SSPFpraktiken i detta kapitel. Aktörer - människor fångar upp idén på det lokala planet och översätter den efter sina intressen och behov (Linde \& Svensson 2013). Dessa aktörer blir inte bara transportörer av idén ut $\mathrm{i}$ praktisk samverkan, utan även transformatörer, vilket här betyder att varje kommun anammar idén om individriktad brottspreventiv samverkan på sitt sätt utifrån hur de lokala aktörerna översätter den. (Johansson, K. 2013). Aktörerna i SSPF är de professionella representanterna för skolan, socialtjänsten, polisen och fritidssektorn i den aktuella kommunen. Ungdom och familj är också aktörer i det faktiska praktiska arbetet, men har inte rollen eller makten att översätta och tillämpa idén om brottspreventiv samverkan, detta ligger i de professionellas makt.

\section{Brottspreventivt arbete på individnivå - ett organisatoriskt fält \\ Utifrån tanken om att brottspreventivt arbete på individnivå och här då specifikt unga individer är ett organisatoriskt fält, möts på detta fält organisationer och dess aktörer. I fallet med SSPF kommer dessa}


professionella aktörer från fyra organisationer och ska gemensamt verka $i$ fältet för ett gemensamt syfte och med en gemensam målgrupp. I fältet kan såväl spänning som likriktning uppstå mellan aktörerna, vilket kommer att visas längre fram i kapitlet.

\section{Att "göra" SSPF}

Denna studie undersöker och analyserar hur en modell som SSPF tillämpas i praktiken, hur den upplevs av aktörerna och hur dessa tolkar och omtolkar SSPF i interaktion med varandra. Intervjuer och observationer i SSPF-sammanhang ligger till grund för denna analys.

De professionella aktörernas agerande och perspektiv rörande organisation och samverkan är huvudfokus i detta kapitel. I kapitel 1 beskrevs hur ett SSPF-möte kan gå till. Nedan presenteras ett typfall som ett exempel på när en ung person aktualiseras för SSPF. Här utgår jag från samma fiktiva exempel som $\mathrm{i}$ inledningen.

\section{Den lokala kontexten - en ungdom aktualiseras} Jonathan är 16 år och går första året vid en kommunal gymnasieskola. Han har haft hög frånvaro den senaste tiden, personalen upplever honom personlighetsförändrad och misstänker att droger kan vara orsaken. Skolans kurator har gjort en anmälan till socialtjänsten tidigare, men ingen utredning inleddes vid det tillfället. Mamma Elisabeth är orolig och säger till kuratorn att hon tappat kontrollen över Jonathan. En kväll påträffas Jonathan av polis i en lägenhet som tillhör en känd äldre narkotikamissbrukare. Jonathan drogtestas och polisen anmäler honom som ett ärende för SSPF och gör samtidigt en ny orosanmälan till socialtjänsten. Samtidigt har skolans kurator hört av sig gällande Jonathan. Så snart som möjligt ska aktörerna samlas för att delge varandra oro och få en samlad bild av situationen runt Jonathan. I den aktuella kommunen finns en SSPF-koordinator, som kontaktar Elisabeth för att berätta om SSPF och inhämta samtycke till informationsutbyte. Koordinatorn kallar till chefsmöte för att beslut om insatser ska fattas. Detta ska sedan följas av ett möte där Jonathan och hans vårdnadshavare deltar, tillsammans med aktörer från de olika organisationerna i SSPF som har någon relation till Jonathan. 
Detta typfall visar hur en ung person kan aktualiseras för SSPF utifrån att någon aktör blivit orolig för den unges utveckling och hälsa. Som vi ska se varierar såväl målgrupp, organisering som insatser beroende på kontext och aktörer i SSPF-arbetet. Den lokala organiseringen av SSPF kan variera en del, men vanligen går det till så vid aktualisering av ungdom att den av samverkansparterna som fattat oro för den unge informerar vårdnadshavare om SSPF och inhämtar samtidigt samtycke till informationsutbyte. Härifrån aktualiseras ungdomsärendet hos styrgruppen genom att koordinatorn för SSPF eller motsvarande kallar till ett möte.

Processen kring inhämtande av samtycke och hur man ser på vem som är mest lämpad för det skiljer sig mellan de studerade kommunerna, men de flesta är överens om att det bör vara någon som familjen har någon form av relation till som inhämtar samtycket. Det skiljer sig också mellan kommunerna hur och om man har diskuterat frågan om vem som inhämtar samtycket och vilken information som ges till vårdnadshavaren om SSPF. Lämpligheten i att polisen inhämtar samtycke har dock ofta diskuterats, men man landar lite olika. I Storstadsdel har man bestämt sig:

...normalt är det ju skolan som inhämtar samtycke, det har vi sagt att vi poliser ska inte göra det, då kan det bli nån sorts tvångssituation och det vill vi ju inte (polis Storstadsdel)

I de tidigaste intervjuerna i Mellanstad ${ }^{30}$ lyftes i ett par grupper att man var rädd från skolans sida att bränna relationen med vårdnadshavaren och tyckte att det var skönt att polisen tog det ansvaret, medan andra tyckte att det var skolan som hade bästa relationen med föräldrarna och därför självklart skulle inhämta samtycket. I Mellanstad tar SSPFkoordinator emot samtycket, kontaktar vårdnadshavare och berättar för vårdnadshavare och ungdom vad SSPF innebär. I Lillestad hade man vid intervjutillfälle två ännu inte tänkt på att göra gemensam sak om denna

\footnotetext{
${ }^{30}$ En omorganisation 2012 gjorde att man gick från fyra lokala SSPF-grupper till en central organisering för arbetet. De första intervjuerna gjordes före omorganisationen.
} 
information. I intervjuerna diskuteras ofta var nivån för aktualisering ska ligga, det vill säga när det är läge för att lyfta ungdomsärendet till SSPF, hur pass stark oron ska vara, osäkerhet råder kring detta.

Om styrgruppen sedan, efter att ha delgivit varandra de olika bilderna av oron kring den unge, enas om att gemensam oro finns bland parterna och att detta är ett SSPF-ärende, kommer man överens om att med gemensamma krafter ge stöd och hjälp till den unge och hens vårdnadshavare. Vissa beslut som kräver mandat, exempelvis gällande extra resurser i skolan, tas i styrgruppen.

Nästa steg blir att arbetsgruppen/verksamhetsnivån träffas och då bjuds vanligen både föräldrar och ungdom in till detta möte. Här ska det mer handfast fastslås "vem som gör vad", en mobilisering av goda resurser runt den unge ska ske (Forkby 2005). I Storstad används för dokumentation av detta något kallat åtagandeplan, där beskrivs vad de olika parterna åtar sig att göra. I Mellanstad hade man vid undersökningsperioden ännu inte använt någon gemensam skriven plan, men planerade att införa det. I stället kom man muntligt överens om vars och ens ansvar. I Lillestad var i skrivande stund ingen ungdom ännu aktualiserad och man hade inte beslutat angående något gemensamt dokument.

\section{Lokal översättning}

När idén om brottspreventiv samverkan runt enskilda ungdomar i form av SSPF översätts till den lokala kontexten visar det sig att den tar sig olika former - den transformeras (Johansson, K. 2013). Anpassning efter det lokala sammanhanget och de lokala behoven sker via de aktörer som finns där. Här formuleras den tänkta målgruppen, de tänkta insatserna och de tänkta resultaten för SSPF (Hjelte $\mathrm{m}$ fl. 2010). I fallet med SSPF packas idén upp på regional nivå hos polismyndigheterna ${ }^{31}$ och i de enskilda kommunerna men kan ibland även packas om där och färdas vidare ut till stadsdelar. I en och samma kommun kan därmed olika översättningar av idén ske och därmed kommer tillämpningen av SSPF

\footnotetext{
${ }^{31}$ Från och med 1 januari 2015 finns endast en Polismyndighet, gemensam för hela landet. Tidigare fanns polismyndigheter i varje län.
} 
att skilja sig mellan kommuner och ibland även inom dessa. Den svenska modellen av SSPF är inte en homogen modell, lika lite som den är det i Danmark $^{32}$. Arbetsformer skiljer sig åt mellan kommuner och ibland inom en kommun med flera SSPF-grupper - översättningen har anpassats till de lokala förhållanden som råder och de aktörer som verkar och samverkar i den lokala kontexten. Aktörerna representerar här sina organisationer och den institutionella praktiken, men också sig själva som individer. Det betyder att de lokala behov som råder, eller bedöms råda av aktörerna, vad gäller exempelvis ungdomsbrottslighet får styra på vilket sätt SSPF tillämpas. Detta gäller såväl målgrupp som insatser.

Målgruppen för SSPF-arbetet är generellt unga personer som anses befinna sig i riskzonen för, eller i en begynnande fas av, kriminalitet och/eller drogmissbruk. Tolkningen av detta, liksom definitionen av insatser, det vill säga såväl vilka ungdomarna är som erbjuds SSPF som vilka interventioner som den unge och familjen kan få, skiljer sig också mellan de undersökta kommunerna. Det är också så att vissa kommuner i Sverige endast arbetar med SSPF på en generell- eller gruppnivå, det vill säga man arbetar förebyggande i bostadsområden och använder samverkansträffarna till att få en gemensam bild av situationen i närområdet. Andra kommuner arbetar såväl generellt som riktat mot individer eller någon identifierad riskgrupp. Denna studie fokuserar uteslutande på den individriktade formen av arbetsformen.

\section{Tillämpning och organisering}

Vad är då egentligen SSPF- modellen och hur ser arbetet ut i praktiken, eller snarare: hur uppfattas och beskrivs arbetssättet av dem som arbetar med det - vilken är den anammade teorin om SSPF (Argyris \& Schön 1977)? I inledningen av uppsatsen beskrevs hur ett SSPF-möte kan gå till och typfallet ovan är ett exempel på hur det kan se ut när en ungdom aktualiseras och ett SSPF-ärende startas. Vad skiljer detta samarbete från det mer konventionella sättet att samarbeta runt ungdomar mellan polis och kommun? En polis uttrycker det såhär:

\footnotetext{
${ }^{32}$ Den danska förebilden SSP beskrevs i kapitel 3
} 
Vi brukar säga att när vi antar... att någon part antar att de vanliga systemen inte räcker till och det är ett kriterie för att starta ett SSPF-ärende, men också det att här behöver vi ha en kraftsamling, att många gör att det går snabbt. Då kan det också vara skäl till ett SSPF-ärende. (samordnande polis Storstad)

Mobiliseringen runt den unge, relationerna i samverkan och undanröjandet av stuprörstänkande nämns återkommande $\mathrm{i}$ intervjuerna. Många respondenter talar också om möjligheten till snabba insatser som något nytt. Man behöver inte vänta på att en utredning från socialtjänsten ska bli klar innan man kan agera runt den unge. Skyndsamhet är ett av fem honnörsord i SSPF i Storstad, det man kallar för "de fem S:en". De övriga är:

Nummer två: vi måste ha samsyn i frågan, har vi det blir S nummer tre: samverkan-inget problem. Och S nummer fyra: specialister ska göra det här jobbet. Ungdomspoliser, särskilt utsedda, särskilt lämpade - inte Lugna gatan och Kris... vi var inte nöjda med det, det måste vara specialister. S nummer fem: synliggöra... Alla måste våga synliggöra dessa ungdomar som är på väg. Hur många gånger har jag hämtat barn på en skola och "ja, det kunde vi förutse att det skulle gå såhär för Kalle"(samordnande polis Storstad)

Återigen talas det om tidiga upptäckter av och åtgärder mot oroväckande signaler hos unga. Detta motiveras ofta, som här med möjligheten att göra dessa konstateranden när det är "för sent" och genomsyrar preventionsarbetet överlag. Riskparadigmet återkommer, vi har en skyldighet att upptäcka och åtgärda, så att ungdomarnas socialisationsprocess kan återupptas.

Organisering på skilda sätt

Även organiseringen av SSPF skiljer sig åt mellan kommunerna i studien. I Storstad finns en övergripande organisering med central samordning av de olika stadsdelarnas SSPF-arbete. Funktionerna i denna samordning är 
två, en från polisen och en från kommunens socialtjänst och dessa stödjer och driver på arbetet ute i stadsdelarna.

Det vanligaste är som beskrivits att det finns två nivåer av samverkansgrupper i SSPF där den första är en styrgrupp på chefsnivå där snabba beslut kan tas och där ärendet som gäller berörd ungdom lyfts upp initialt. Styrgruppen består vanligen av personer i ledande funktioner från de olika deltagande myndigheterna såsom rektor, fritidsgårdschef och enhetschef vid socialtjänsten. Om styrgruppen enas om att gemensam oro finns bland samverkansparterna för den aktuelle unge så går ärendet vidare till en arbetsgrupp/verksamhetsgrupp. I arbetsgruppen/verksamhetsgruppen finns vanligen personer som arbetar i direkt kontakt med den unge, såsom lärare och/eller kurator från skolan, fritidsledare eller exempelvis fotbollstränare och handläggande socialsekreterare. I Storstadsdel och Lillestad är det bestämda personer som ingår i styrgrupp respektive arbetsgrupp/verksamhetsgrupp, även om dessa givetvis byts ut ibland av naturliga skäl. I Lillestad skiljer sig också gången på ärendet, då det är arbetsgruppen som diskuterar den unge initialt och därefter inhämtar beslutsmandat från ledningsfunktioner. Här menar man att det specifika med den lilla kommunen gör detta möjligt. Styrgruppen träffas bara vid strategiska SSPF- möten en gång per år.

I Mellanstad har man olika personer som ingår i styrgruppen/chefsmötet beroende på vilken skola ungdomen tillhör, vilken fritidsgård som eventuell är aktuell och vilken avdelning inom socialtjänsten som handlägger ungdomen. Detsamma gäller här på verksamhetsnivån. Däremot är det ofta samma polisman som finns med i SSPF-arbetet, samma person deltar i såväl chefsgrupp som vid verksamhetsmöte. Skälet till detta menar poliserna i Mellanstad beror på att polisledningen inte prioriterar detta arbete. En polis uttrycker detta:

Nu är jag ju väldigt engagerad, jag brinner för det här. Men polisområde Mellanstad har ingen organisation där, om jag slutar så är det nån annan som ska in och ta det här utan då kommer det att bli liksom en överraskning för många att "jaha, ska nån gå in och ta 
det här och vad är det för något?” Så ser det ut idag

(polis 1, Mellanstad).

\section{Koordinatorns roll}

Koordinatorernas roll är central och viktig för att hålla en kontinuitet $i$ arbetet, sammankalla till möten och sköta det administrativa. Detta framgår i de intervjuer som gjorts där koordinatorer finns, i Mellanstad och Storstad.

En samordnande funktion för SSPF- arbetet finns i Storstads alla stadsdelar, i några stadsdelar finns flera:

En framgångsfaktor som vi drivit igenom är den personen. /.../ I stadsdel A har man fyra stycken koordinatorer, de ser vinsten av detta. För effektivt arbete här, det sparar ju enormt mycket pengar, färre barn som blir omhändertagna. De håller liv $i$ arbetet, håller ihop(samordnande polis Storstad).

Här förutsätts att detta arbetssätt ska "spara enormt mycket pengar" genom de tidiga insatser som kan genereras i SSPF-arbetet, vilket motiverar kostnaden för koordinatortjänsterna. I Mellanstad delar utbildningsförvaltningen och socialförvalningen på 50 procent av tjänst för en koordinator, denna är tillsatt efter omorganisationen i december 2012. Funktionen var mycket efterfrågad främst från polisens håll. I de första gruppintervjuerna i Mellanstad som hölls våren 2012 återkom man inom den lokala polisen till denna "dröm" om en koordinator för arbetet, vilket realiserades i slutet av samma år. Koordinatorsollen ser även den olika ut i de undersökta kommunerna. I Lillestad finns ingen utsedd koordinator, men en del administrativt ansvar ligger på personen som ansvarar för det brottsförebyggande arbetet $\mathrm{i}$ kommunen.

Organiseringen av SSPF sker således på olika sätt i de undersökta kommunerna, även om det finns en kärna av likhet. Organiseringen har skett utifrån de olika lokala kontexterna och aktörerna och hur dessa har tolkat idén om SSPF och sedan tillämpat den i den lokala praktiken. 


\section{De professionella aktörerna}

Samverkansaktörerna i SSPF blir bärare av idén i den lokala kontexten.

De kan också bidra till att idén om och tillämpningen av SSPF förändrasnyöversätts - varefter behov av detta definieras. Även här kan samverkan komma att ställas på prov när de olika institutionella logikerna ska förstå det gemensamma syftet med och tillämpningen av SSPF. Samsyn ska uppstå, inte bara en gång utan för varje nyöversättning, varje transformation av arbetssättet (Johansson, K. 2013). De olika aktörerna har att representera sin organisation men också interagera med övriga aktörer i samverkan, de ska bibehålla gränser samtidigt som gränser ska överskuggas. De fyra organisationer som bildar SSPF och dess aktörer framträder på skilda sätt i studien utifrån det empiriska materialet, vilket tydliggörs nedan.

\section{Skolan viktig men ambivalent}

Den arena och samverkanspart i SSPF som av övriga lyfts fram som viktigast för tidig upptäckt av de aktuella unga är skolan. Dels därför att alla ungdomar förväntas vara i skolan dagligen, åtminstone $i$ grundskolan, men också därför att skolan många gånger har en etablerad kontakt med föräldrarna och kan ha en mer neutral roll när SSPF presenteras för dem.

I Lillestad var man i ett skede bekymrade över att skolan varit alltför passiv i SSPF-arbetet en tid:

Sen har vi ju inte haft ... ja vi har ju haft personer från skolan, det har vi ju faktiskt, kurator ja, men på nåt vis känns det inte som de varit delaktiga hela vägen eller? Man tappar dom lite grann ... jag vet inte vad det beror på, ofta är det så att skolan är lite för sig själv, det är svårt att komma in i skolan, det vet vi ju om (brottsförebyggare Lillestad).

I de fall den unge tillhör en gymnasieskola i Mellanstad och anledningen till oro är bekräftat drogmissbruk, stängs eleven av från skolan till dess att ett negativt drogtest kan visas, vilket kan ta tre - fyra veckor. Det 
betyder inte att skolan helt stänger kontakten med eleven, men hen får inte vistas där under den tiden. Det betyder att ungdomen inte har någon fast sysselsättning under avstängningstiden, vilket kan skapa bekymmer och i värsta fall ha motsatt effekt. Går eleven i grundskolan kan hemundervisning sättas in under en begränsad period. Skolans del av insatser i SSPF kan annars vara extra resurs för stöd i undervisningen, anpassad studiegång med praktik eller liknande speciallösningar. Vid de möten jag observerat agerar skolans aktörer olika vad gäller vilja och ambition att lägga resurser på ytterligare speciallösningar, man kan ha provat det mesta redan och är uppgivna eller har svårt att hitta resurser.

Skolan är en viktig skyddsfaktor - kanske den viktigaste vid sidan av familjen - för den unge (Vinnerljung 2011, Andershed \& Andershed 2010). Skolan är också den arena där störst möjlighet till relationsskapande och insatser bör finnas. Samtidigt gör regelverket att ungdomar inte kan vistas i skolan under perioder, vilket gör att det blir svårt för skolan att uppfylla de förväntningar som finns. Studien visar också att alla skolor inte inkluderas i SSPF-arbetet, de passar inte in i de kommunala geografiska strukturer som man utgått från i tillämpningen av SSPF. Man är dock medveten om detta i såväl Mellanstad som Storstad och försöker hitta lösningar på problemet. I Mellanstad har man kontakt med alla fristående grund- och gymnasieskolor och har informerat rektorer och kuratorer om SSPF.

\section{Socialtjänsten bär ansvar men blir otydlig}

Socialtjänsten är den aktör som har det övergripande ansvaret för att samverkan runt barn som riskerar att fara illa kommer till stånd (SoL \ 5 kap 1). Som vi sett är det dock polisen och inte socialtjänsten som initierat SSPF och liknande arbetsformer, samverkansöverenskommelser med mera. Socialtjänsten förväntas trots detta vara de som driver arbetet framåt och tar det yttersta ansvaret för denna samverkan. Många gånger har socialtjänsten redan kännedom om den aktuelle unge, men aktualiserar färre ungdomar till SSPF än skola och polis i de undersökta kommunerna. I intervjuer och observationer blir socialtjänstens roll trots detta lite otydlig, då det på vissa håll ser ut som att interventionerna från socialtjänstens sida tycks bli ungefär desamma som de hade blivit utan SSPF. Storstadsdel skiljer sig på denna punkt, där ges samma 
intervention till alla SSPF-ungdomar - skolteamet. Skolteamet framför dock att de saknar fortsatt kontakt och återkoppling från socialtjänsten efter att den unge blivit placerad där.

Övriga parter i SSPF-samverkan framför ibland kritik och frustration över att socialtjänsten inte agerar snabbare eller förändras till att ingripa tidigare, tydligast här är aktörerna från polisen. Men man menar också att socialtjänsten borde ha stor hjälp av SSPF i såväl utredningsarbetet som i planering av interventioner. Ibland upplever man det svårt att få socialtjänsten helhjärtat med i arbetet, kanske då det samtidigt pågår en barnavårdsutredning. Följande citat illustrerar detta:

\section{Myndighetsutövande socialsekreterare vill skärma av sig och gör sin del (koordinator i enkät).}

I de observationer av SSPF-möten som gjorts i studien hade - eller tog socialtjänstens representanter relativt lite talutrymme jämfört med till exempel polisrepresentanterna. Trots detta är man i studien övervägande positiv till arbetsmodellen SSPF från socialtjänstens sida.

\section{Polisen som pådrivare och socialarbetare}

I flera av intervjuerna framkommer att polisens roll är central och viktig $i$ SSPF-arbetet. Som tidigare beskrivits har Polismyndigheten på riksnivå, men även lokalt på många håll, initierat samverkansöverenskommelser och SSPF-arbete. I Storstad menar man att arbetet skulle stanna upp om inte polisen drev på:

...det är omöjligt att göra en åtagandeplan utan att polisen är med/.../ det har vi lärt oss, man kommer inte till skott, vi får vara med som en motor /.../risken är att det tenderar att bli lite "bullmöte". Då behövs det: "kolla nu åtagandeplanen, var tog polisen vägen, prioriterar ni bort det här och så vidare"(samordnande polis Storstad).

Polisen lyfts fram, både av sig själva och av samverkansparterna, som den myndighet som bidrar med mest information till de övriga

...det är ju poliser som är ute på fält, det är ju poliser som ser vad som händer och vet, har mycket information om 
vad som händer. Och när dom då driver på den informationen...här ser vi...här måste vi...det är det som triggar igång att andra kommer igång (koordinator Storstad).

Polisen framstår i studien som den part som lägger störst vikt vid SSPFarbetet och därför är pådrivande, såväl i initialskedet som under arbetets gång, även om man $\mathrm{i}$ intervjuer lyfter socialtjänstens centrala roll. I Mellanstad har man dock haft svårigheter inom polismyndigheten att hålla kontinuitet och prioritet $\mathrm{i}$ arbetet, mer om detta senare i kapitlet.

I denna studie framträder också bilden av polisens olika roller i SSPFarbetet, ett exempel är den pådrivande rollen, en annan den kontrollerande rollen. Polisen informerar övriga parter i SSPFsamarbetet om läget runt den unge och tar också på sig en kontrollerande roll i alliansen med föräldern, det vill säga polisen tar på sig ansvaret för att hålla koll på den unge och informera föräldrarna om vad som försiggår och i vilka kretsar deras ungdom umgås.

Utöver rollerna som pådrivare och kontrollfunktion framträder i studien också bilden av polisen som socialarbetare. Detta kan bero på att poliser på många håll är de tjänstemän som träffar ungdomar ute på kvällar och helger, kanske saknas det fältarbetare från socialtjänsten och polisen tar en sådan roll i viss mån. Men polismän tar på sina håll också ett vidare socialt ansvar:

Vi vill lära känna dem (ungdomarna, min anm.), det blir så otroligt mycket lättare när vi träffar dem på torget klockan 11 en fredagskväll när vi känner dem. Som nu är vi ute på lägerverksamhet, va ... alla sjundeklassare $i$ Storstadsdel får åka på läger i några dagar och då är vi med också, det är mycket värt (polis Storstadsdel)

Polisens sociala roll lyfts inte bara fram av berörda polismän utan även från Polisledningshåll:

För jag vet att dom människor som är i nöd, dom förlitar sig ofta till oss poliser /.../Så jag skulle vilja se det som en större hjälp till familjen. En områdespolis eller en närpolis, familjen har oftast direktnumret, men det bygger ju oftast 
på att man tar telefonen även om det är tre på natten och där är vi ju inte än. Men dom intresserade poliserna dom tar det samtalet klockan tre på natten (samordnande polis Storstad)

Citaten illustrerar att poliserna här ser sin roll som långt mer än bara den repressive polisens. Såväl förebyggande som socialt arbete blir viktigt och i vissa fall går poliser in i arbetsuppgifter som traditionellt sett hört mer hemma i socialtjänsten.

Fritidssektorn anses viktig men är osynlig Den fjärde parten i SSPF-samarbetet, fritidssektorn, är svårare att fånga i studien. De ungas fritid är en viktig pusselbit som måste innehålla positiva aktiviteter för att en ung person i riskzonen ska bryta en negativ bana. Man har på många håll i Sverige lyft in fritidssektorn i samarbetet för att:

Fritiden är jätteviktig och en underskattad resurs i socialt arbete med barn och unga.( koordinator i enkätsvar)

Fritidssektorn kan ibland ge en lite annan, mer positiv bild av den unge än vad som annars brukar vara vanligt från övriga samverkansparter:

... det var bra med den här breda bilden, för när vi hade första ärendet så fick vi ju en väldigt positiv bild av den här grabben har jag för mig från fritidsgården - och då fick vi höra att det fanns en miljö där han fungerade. För skolan hade en så oerhört destruktiv bild av den här eleven (representant från skolan Mellanstad).

Fritidssektorns representanter har trots detta inte någon aktivt framträdande roll i Lillestad eller Mellanstad, medan fritidsaktiviteter alltid ingår i de åtgärdsplaner man tar fram för varje ung person $i$ Storstadsdel. Man menar där att fritidsledarna kan fungera som brobyggare mellan ungdomarna och övriga samhället. I Lillestads SSPFgrupp var man i de första intervjuerna bekymrad för att fritidsgården visat svalt intresse för SSPF och gruppen diskuterade att personalen på fritidsgården inte riktigt tog sitt vuxenansvar. 
Resultaten visar att fritidssektorn i SSPF uttrycks som viktig men detta ter sig i praktiken inte helt naturligt och enkelt på alla håll. En koordinator i enkätsvar uttrycker sig såhär:

Min personliga åsikt om varför de ofta inte ingår i arbetet är att personalen inte är akademiskt utbildade och använder ett annat yrkesspråk som inte håller måttet för samverkan. Det skapar osäkerhet hos de andra parterna

I Mellanstad menar koordinatorn att fritidsgården också är en viktig part i kontrollen av ungdomen, men att de ändå inte finns med i det fortsatta arbetet, något som kan bero på att den unge slutat gå på fritidsgården, eller blivit avstängd därifrån på grund av sitt beteende:

Jag skulle vilja nämna fritid, för fritid är ju en jättefriskfaktor, men ofta när man säger fritid så tänker man på fritidsgården och våra strulungar. När dom blir tillräckligt struliga så är dom inte kvar, men däremot så kan man få höra mycket från fritidsgården ... eh ...men så tappar vi dom.

En tolkning av detta är, att varken fritidssektorns representanter eller övriga aktörer hittat formen för hur den uttalat viktiga fritidsdelen ska ha en mer aktiv roll i SSPF och hur den ska se ut. Men en fråga väcks också: varför har man inte lyckats med detta om man anser att fritidssektorn är så viktig för den unge? Kan det vara en fråga om status, då övriga parter på något sätt är myndighetsutövande men fritid inte har ett sådant uppdrag?

\section{Förutsättningar för arbetet}

I beskrivningen ovan diskuteras de fyra parternas olika roller i SSPFarbetet såsom de framstår i studien. I det kommande behandlas själva samarbetet mellan aktörerna och förutsättningar för arbetet med SSPF.

Den professionella alliansen

I SSPF är grunden för arbetssättet att de professionella i de fyra organisationerna kommer samman och arbetar brottspreventivt med gemensamma mål i sikte. En allians bildas, antingen tätt sammanhållen, 
som i Lillestad, eller lite lösare sammansatt, som i Mellanstad. Detta är en av de allianser som bildas i SSPF, den professionella alliansen som Forkby \& Larsen(2005) beskriver som "de goda krafterna" mobiliseras runt den unge och strategier för att hjälpa den unge och familjen skapas. Forkby (2006) menar att allianserna kan ha två huvudspår, där ett är ett strategiskt samordnande av aktörernas resurser och ett annat handlar om utveckling av nya arbetssätt. Med koppling till Forkbys sätt att se det så har SSPF i de tre undersökta kommunerna strävat att uppfylla alliansens båda spår, man arbetar för att samorganisera sig och nå de samverkansvinster som leder till effektivitet men man arbetar också med att försöka implementera och utveckla SSPF-arbetet.

Betydelsen av själva mötet, att fysiskt träffas och få ansikten på varandra i samverkansgrupperna framträder i materialet som en annan framgångsfaktor. Det upplevs enklare att ta kontakt när man vet vem man ringer till och i de grupper där samma personer träffas återkommande blir "vi-känslan" tydlig. I Lillestad hade man arbetat tillsammans sedan tidigare och man såg den redan inarbetade gruppen som en viktig framgångsfaktor för SSPF-arbetet. Man hade inlett arbetet med studiebesök i andra SSPF-kommuner och ett gemensamt internat, där man planerat för SSPF- arbetet samt haft sociala aktiviteter som att laga mat tillsammans.

Men det vi säger när vi är ute och berättar om SSPF och som vi ser som en jätte-framgångsfaktor, det är ju att vi jobbat ihop gruppen så bra, det är verkligen en framgångsfaktor att vi går så väl ihop, det är jättepersonbundet på det viset (brottsförebyggare Lillestad).

Även i Storstadsdel talas om relationerna i gruppen som förutsättningar för ett lyckat samarbete. Man resonerar kring förhållandet person/funktion:

... och vi har ju samarbetet under så lång tid så vi känner varann väl, det handlar ju till stor del om relationer även här, även om det inte är baserat på det egentligen, det 
Man skulle önska att man kunde säga att det är byggt på funktion och inte person, men det är byggt på förtroendefrågor och det tar ett tag att bygga upp (polis Storstadsdel).

Om Lillestad står för "den tighta gruppen", så kan man i Mellanstad beskriva samarbetet som "den löst sammansatta gruppen". Detta är fallet efter den omorganisation som gjordes i kommunens utbildningsförvaltning och socialförvaltning under 2012. I de intervjuer som gjordes före omorganisationerna, då grupperna bestod av bestämda personer, framstod även mötet och relationerna mellan de olika samverkanspersonerna som viktigt. Idag är det koordinator och vanligen samma polisman som genomgående deltar vid såväl styrgruppsmöten som verksamhetsmöten. Man har försökt få en polis på chefsnivå till styrgruppen, han har deltagit ibland men har några gånger endast kunna delta i styrgruppsmötet per telefon. Relationerna mellan aktörerna framgår inte som lika viktigt i Mellanstad, som i de övriga två kommunerna. Då personerna i SSPF-grupperna varierar här blir funktion viktigare än person och personkemi är inte något som lyfts särskilt av Mellanstads aktörer (jfr Danermark 2004).

Det ser alltså olika ut $\mathrm{i}$ kommunerna vad gäller hur stor vikt man lägger vid person respektive funktion och hur känsligt arbetet är för förändringar i alliansen. Längre fram i kapitlet återkommer detta i resonemang om instabilitet i organisationer och dess inverkan på SSPFarbetet.

\section{Spänning... och likriktning}

Samverkansaktörerna i SSPF kommer från olika kunskapstraditioner vad gäller utbildning och teoretisk grund, olika kulturer gällande synen på ungdomskriminalitet och har därmed delvis olika syn på lösningen av problemet. Deras respektive institutioner kan även ha olika syn på den 
egna organisationens roll i samverkan liksom synen på övrigas roller, vilket dock inte alltid är uttalat. Med detta menas teoretiskt att den konkreta organisationen motsvaras av en institution som på ett mer abstrakt plan står för normer och tankemodeller - en institutionell logik (Linde \& Svensson 2013, Johansson, S. 2011a). Tidigare studier har visat på svårigheter i samverkan mellan polis och socialarbetare gällande ungdomsbrottslighet, på grund av dessa skillnader (Forkby \& Larsen 2005). Dessa skilda institutionella logiker - den kollektivt delade uppfattningen i respektive organisation (Linde \& Svensson 2013, s.13) framträder ibland i materialet genom att frustration, främst från polisens håll mot socialtjänsten, visar sig. Det handlar oftast om att socialtjänsten inte lever upp till förväntningarna med SSPF - att ingripa tidigt och snabbt. En polis beskriver en situation när han blev frustrerad då han hade andra förväntningar på vad som skulle hända efter SSPF-mötet:

\begin{abstract}
Och vad gör socialtjänsten? Skickar ett brev till den här mamman och skriver att vill du ha hjälp så når du oss på det här numret, man häpnar ju, för man tycker att ett besök hos den här mamman och ta reda på vem som var den här tränaren och så vidare... ja, han (ungdomen), fortsätter ju att strula alltså.... (polis 1, Mellanstad)
\end{abstract}

Olikheter $\mathrm{i}$ institutionell logik mixas i vissa sammanhang $\mathrm{i}$ arbetet med likriktning. Likväl som spänningar och konflikter kan förekomma i SSPF-samverkan, så kan en tendens av likhet mellan organisationer och dess aktörer uppstå. Då ser vi i stället att aktörerna enas kring behovet av mobilisering runt den unge, att de gemensamma målen för arbetet är uttalade och att polisens sätt att arbeta ibland påminner om socialarbetarens medan socialtjänst och skola återkommande betonar vikten av kontroll runt den unge. Det behöver inte vara ett problem men kan i tillspetsade situationer ändå skapa förvirring hos såväl de enskilda unga och familjerna som hos övriga parter i samverkansmodellen. I grunden har samverkansparterna sina specifika uppdrag och sin specifika lagstiftning att följa och när detta luckras upp kan det i vissa fall få 
negativa konsekvenser samtidigt som det kan öka förståelsen mellan aktörerna i samverkan. En kluvenhet råder alltså i detta.

Vi skönjer således såväl spänning som likriktning i SSPF-arbetet, här framträder såväl skilda institutionella logiker som drag av isomorfism.

\section{Implementering är svårt}

Det tar tid att etablera ett nytt arbetssätt i organisationer, vilket också blir tydligt i studien. Implementering av idéer i organisationer, hos individer och i samverkansarbete är beroende av såväl organisation och ledning, de individer som agerar och den mån av enighet kontra konflikt som råder mellan aktörerna i samverkan, främst avseende såväl gemensamt problem som lösningar på problemet (Alexandersson 2006; Matland 1995). Hur tolkas och omtolkas idén i den lokala kontexten?

I Storstadsdel fick man stor draghjälp av att det gjordes en mycket stor satsning mot rekrytering till kriminella gäng i hela Storstad, vilket innebar att avsevärda ekonomiska medel avsattes för arbetet både inom kommunen och polisen. Initiativet till den stora satsningen kom från polisen i Storstad och avtal om brottsförebyggande samverkan skrevs med kommuner och stadsdelar. Detta gjorde att man kunde satsa såväl centralt som i de lokala stadsdelarna och bostadsområdena och SSPF blev en av insatserna som skulle etableras i alla stadsdelar:

... det skulle inte diskuteras så mycket utan det var bara "här är pengarna - gör". Gud vad roligt... (koordinator storstadsdel).

Den centrala funktionen som inrättats i Storstad blev pådrivare för att arbetet skulle komma igång i stadsdelarna.

Också i Mellanstad var det polisen som initierade SSPF-arbetet, som blev en del av samarbetsavtalet med kommunen. År 2011 arbetade man fram en rutin inom kommunen som förutsattes få spridning till skolor och inom polis och socialtjänst

SSPF-modellen här i Mellanstad, den har ju funnits ett tag och implementerades för många år sen fast ändå är det många skolor som inte känner till det, vilket jag kan tycka 
är konstigt, att dom inte har en aning om det här (polis Mellanstad).

... har egentligen aldrig varit nån samling, där vi på rektorsträff har pratat om innehållet $i$ det här, eller fått nån återkoppling sen det kom ut, utan det kom bara sen som en papperslunta, mycket pappersluntor till rektorerna, så jag förstår om en del rektorer missat det här (rektor Mellanstad)

Det fanns därvidlag inte någon självklar förankring i skolan trots att en ny rutin togs fram. Även inom polisen och socialtjänsten gick det trögt med förankringen i Mellanstad. Polis och kommun arbetade om rutinen för SSPF och kommunen anställde en koordinator samt centraliserade arbetet efter omorganisationerna. Förankringen har blivit bättre, men polisen anser att den kan bli mycket bättre i den egna organisationen, det är endast ungdomspolisen som känner till arbetet menar man.

I Lillestad hade man goda förhoppningar om arbetet vid starten, den "tighta gruppen" var ute på skolor och i andra sammanhang för att informera om den nya möjligheten att arbeta runt unga personer. Arbetet startade operativt vid årsskiftet 2013/14 och man hoppades att ungdomsärenden skulle strömma in. Vid gruppintervju i juni 2014 och uppföljning i juni 2015 hade man ännu inte haft något ärende i SSPFprocessen. Gruppen hade inte någon enkel förklaring till detta utan rannsakade sig - det kunde handla om omorganisation, att förälder sagt nej till samtycke, "alla känner alla" i den lilla kommunen eller att alla parter inte var villiga att samverka. I det sistnämnda syftade man på fritidsgården, där man menade att fritidsledarna var rädda att bryta sin förtroendefulla relation med ungdomarna genom att signalera oro till SSPF.

... men det är lite synd, man är rädd för att bränna sina skepp gentemot ungdomarna och det är inte alltid det gagnar ungdomarna (representant från socialtjänsten Lillestad). 
"Det känns lite svajigt nu". Instabilitet i organisationer skapar osäkerhet i samverkan

Omorganisationer eller förändringar i mindre skala påverkar arbetet i den egna organisationen, men studien visar också att det i högsta grad även påverkar de samverkande organisationerna och deras representanter

I Mellanstad startade SSPF år 2011 i de dåvarande fyra geografiska områden som var organiserade utifrån socialkontor, skola och fritidsgårdar. Det betyder att det fanns fyra styrgrupper där SSPF ärenden aktualiserades. Jag genomförde gruppintervjuer i tre av dessa fyra grupper och det blev tydligt att man arbetade olika i områdena, likväl som det kunde rå oenighet inom grupperna gällande målgruppen, åtgärder med mera. Arbetet hade ännu inte funnit sin form. Därefter - år 2012 - startade omfattande omorganisationer inom såväl den lokala polisen som inom berörda förvaltningar i kommunen, vilket påverkade SSPF- arbetet:

Alltså, jag kan väl känna såhär, att vi har drabbats i den här processen av omorganisationer som har gjort att tempot sjunkit ganska rejält och först var det vi (polisen)... sen var det utbildningskontoret och nu socialtjänsten, så att...vi har haft lite otur där (polis i Mellanstad).

I Storstad gjordes en stor omorganisation 2010, då antalet stadsdelar halverades, vilket också fick konsekvenser för SSPF- arbetet:

Vi förstod att då måste vi göra något åt det här, för det blev nya förutsättningar, en spännande resa! Och det kan man väl säga att i två års tid hade dom (stadsdelarna) väl fullt upp med sig själva (koordinator Storstad).

Omorganisationen gjorde dock att man från centralt håll såg möjligheter att ta nya tag med samverkansarbetet och sträva efter mer likhet $i$ stadsdelarnas SSPF-arbete:

... då var uppdraget: SSPF ska bli vassare, man ska känna igen sig i forumet, det ska bli mer likformat i stadsdelarna och alla ungdomar ska ha rätt att komma in i forumet om behov finns (ansvarig polis Storstad). 
I Lillestad startade man SSPF-arbetet genom att en redan etablerad samverkansgrupp som kände varandra väl tog till sig modellen. Redan under första året slutade flera personer $\mathrm{i}$ gruppen, vilket också skapade osäkerhet:

Det känns ju lite svajigt som sagt, vi får börja om på nytt och försöka tajta ihop en ny grupp. För det är det vi har pratat om hela tiden att vi har varit en så väl sammansvetsad grupp som har kunnat samarbeta på ett bra sätt, så även om vi inte har fått in några ärenden så har det här runt omkring funkat jättebra. Så ja, det tycker jag, det känns svajigt (brottsförebyggare Lillestad)

I Lillestad saknade man länge fritidssektorn i arbetet och man upplevde under en tid att skolans roll blivit mer passiv. Ett rektorsbyte vid den enda högstadieskolan påverkat arbetet på så vis att skolan var frånvarande och mer passiv en tid.

SSPF-arbetet påverkas på olika sätt av omorganisationer i större skala, men det påverkas också av mindre förändringar, som exempelvis byte av individer i viktiga funktioner. Detta blir särskilt tydligt inom socialtjänsten där personalomsättningen varit extra hög i många kommuner och där man ibland prioriterat bort eller ned samverkan för att klara vardagen. Omorganisationer skapar oro inte bara i den egna organisationen utan även i de samverkande, arbetet stannar upp och en ovisshet över framtiden ger instabilitet även i samverkan (Danermark \& Kullberg 1999). Instabilitet i själva SSPF- gruppen blir i Lillestad mycket påtagligt och kan ha större konsekvenser för SSPF-arbetet än instabilitet i de samverkande organisationerna, här framstår arbetet som mer personbundet än i de övriga kommunerna.

I Mellanstad framkommer både hos polis och övriga i gruppintervju 2014 en oro inför Polisens stora omorganisation i hela riket år 2015, man var rädd för att ungdomsarbetet skulle få ytterligare stå tillbaka, vilket man upplevt att det gjort de senaste åren. I Storstad och Lillestad däremot var de intervjuade poliserna övertygade om att det brottsförebyggande arbetet i stället kommer att stärkas i den nya polisorganisationen. 
Liksom det handlar om såväl individuella som organisatoriska faktorer när det gäller implementering, gäller det även vid omorganisationer av den egna eller de övriga aktörernas organisationer. Ledarskapet blir särskilt viktigt $\mathrm{i}$ hur omorganisationen tas emot av individerna $\mathrm{i}$ organisationen. Kontexten där omorganisationen äger rum kan fungera antingen som hinder eller som möjliggörare för det nya, beroende på klimat och kultur i organisationen (Ginsberg \& Tregunno 2005). I fallet med SSPF ser det ut som samverkansarbetet kommer i andra hand när en organisation ska omdanas, man smalnar av till fokus på den egna organisationen och har inte kalkylerat med hur det påverkar samverkansparterna eller de familjer som man samverkar kring.

Instabilitet i organisationerna grusar strävan efter det framgångsrika samverkansarbetet i SSPF.

\section{Utmaningen med samverkan}

Det är således en mängd faktorer som påverkar hur SSPF-arbetet fungerar i den lokala kontexten. Det handlar om hur den lokala anpassningen av arbetssättet sker - hur man definierar målgrupp, insatser och resultat lokalt men också om hur själva samverkansprocessen fungerar.

Den samlade samverkansforskningen visar på att faktorer rörande struktur, process, ekonomi och professioner påverkar utfallet av samverkan. Strukturella faktorers påverkan på samverkansarbetet är framträdande i studien, det handlar om styrning och prioritet för arbetet $i$ de olika organisationerna, men också om implementering och stabilitet i organisationerna. En viktig fråga att ställa i varje samverkansform mellan människobehandlande organisationer är huruvida samverkan sker för organisationens eller brukarens bästa. En annan fråga är om fokus hos samverkansaktörerna ligger på den egna organisationens åtagande, eller om det är samverkansprocessen som är i fokus. Horwarth \& Morrisons (2007) modell över gradering av samverkan passar särskilt bra här. De talar om fem nivåer av samverkan, där kommunikation, det vill säga informationsöverföring, är den lägsta och integrering den högsta. Enligt Horwath \& Morrisons modell ligger det första, fokus på den egna organisationens åtagande, på den lägsta nivån av samverkan, där det endast handlar om informationsöverföring. Huvudfokus på 
samverkansprocessen och det som ska komma ut av den, ligger däremot på den högsta nivån av samverkan, integration (ibid). Detta ligger i linje med Danermark \& Kullberg (1999), där de summerar framgångsfaktorer och försvårande faktorer för samverkansprojekt. Framgångsfaktorerna har en koppling till projekt där hög grad av integrering skett mellan aktörerna. De faktorer som gynnar integrering är gemensamma mål, gemensamma lokaler, samordnad ledning och administration och tydligt beskrivna gränser och huvudmannaskap samt lagarbete. Det är få av dessa faktorer som uppfylls i SSPF-modellen, i stället kan de hämmande faktorerna såsom skilda kunskapstraditioner, olika ekonomiska intressen, etiska regler, asymmetriska relationer lyftas som mer eller mindre närvarande i SSPF-processen (Danermark \& Kullberg 1999, Grape 2006). Det är också här som spänningen mellan de institutionella logikerna kommer in.

Som tidigare beskrivits finns i SSPF- kommunerna i studien skrivna avtal om samverkan mellan polismyndigheten och kommunen, det finns handlingsplaner för SSPF-arbetet där gemensamma mål har tecknats ned, om än på övergripande nivå ibland. Enligt Horwath \& Morrison (2007) så höjer detta nivån på samverkan. Här finns också beslut tagna på ledningsnivå, involvering av chefspersoner (om än inte alltid) och mandat för aktörerna att samverka. Detta skulle göra att SSPFsamverkan enligt modellen hamnar på tredje nivån - samordning (coordination), då vi kan skönja gemensamma strukturer, formaliserade avtal och högre intensitet i samverkan. I de högsta nivåerna i den teoretiska modellen handlar det om att organisationerna går från autonomi till samverkan, det vill säga att samverkan går före den enskilda organisationens intresse och alla beslut fattas gemensamt (ibid). Hit är det långt kvar att nå för SSPF-samverkan, frågan är om det skulle vara motiverat att ta samverkan i arbetsformen SSPF så långt och vad det faktiska resultatet skulle bli av detta.

\section{Sammanfattning och reflektion}

Kapitlet har fokuserat på hur SSPF beskrivs av de samverkande parterna, på de samverkande organisationerna, dess representanter och den interaktion som sker dem emellan i SSPF-samverkan. Socialtjänstens roll 
i SSPF framstår som lite otydlig i resultaten trots att dess roll är otvetydig i dokument och lagtext. Socialtjänsten har ansvaret för att initiera samverkan, men det är sällan socialtjänsten aktualiserar någon inom ramen för SSPF. Det är vanligare att skolan eller polisen gör detta. Polisens roll blir desto tydligare, framför allt som pådrivare av SSPF och den mest kontrollerande parten - men också som den aktör som lyfter fram det sociala ansvaret och även agerar i roller som påminner om fältarbetande socialarbetare. Skolan anses som den viktigaste arenan för att nå de unga men kan i sin roll markera avstånd och till och med avvisa elever $^{33}$, vilket varken polis eller socialtjänst kan göra. Fritidssektorns roll är otydlig och relativt osynlig i materialet, även om den framställs som viktig av övriga aktörer.

Arbetet och upplägget med SSPF skiljer sig åt mellan kommunerna. Vissa likheter finns- det självklara med samtycket till informationsutbyte och grupper på olika nivåer med lite olika mandat. Syftet med arbetet är också lika, man vill kraftsamla och bygga strukturer runt den unge, något som exempelvis Torbjörn Forkby (2005) kallar logistiska praktiker, att få ihop logistiken runt den unge, medan Bengt Börjeson (2010) talar om aktivering av resurser. Begreppet alliansskapande omfattar detta.

Utöver detta gemensamma är variationen ganska stor vad gäller processen i SSPF.

Samarbetet är känsligt för instabilitet i organisationer och hur implementeringen av SSPF gått till, de förutsättningar som råder för att få till stånd arbetet ser också de olika ut i kommunerna.

Förutsättningarna påverkar på organisation/professionsnivå, men kan också komma att påverka individnivån, de ungdomar och familjer som berörs.

I talet om SSPF-arbetet är det för dessa ungdomar som brottspreventiv samverkan på individnivå och samverkansformen SSPF skapats och gjort sin resa till det lokala planet. Hur ser då samspelet mellan samhällets aktörer och familjen ut? Detta är i fokus i kapitel 8.

${ }^{33}$ Gäller gymnasieskolan. 


\section{Allians mellan praktik och familj}

... visar på att flera vill hjälpas åt, fler som kan stötta/slå larm/erbjuda personligt engagemang för ungdomen och familjen (koordinator i enkätsvar)

I kapitel 7 låg fokus på organisatoriska förutsättningar för SSPF-arbetet och interaktionen mellan de samverkande parterna skola, socialtjänst, polis och fritid - den professionella alliansen. I detta kapitel lyfts i stället interaktionen mellan SSPF-aktörerna och familjen fram utifrån de resultat som handlar om de professionella i förhållande till den unge och familjen. Kapitlet inleds med de resultat som behandlar själva målgruppen för SSPF-arbetet, då det visat sig att definitionen av den tänkta målgruppen varierar. Därefter behandlas samtycket till informationsutbyte, där arbetet är beroende av föräldrarnas medverkan och alliansen mellan samhälle och familj - eller egentligen samhällets representanter och förälder - som skapas i arbetet. Utöver detta lyfts vad i övrigt som SSPF-arbetet kan leda till för ungdom och familj.

\section{Vilka är ungdomarna i SSPF?}

Vi börjar skönja att SSPF inte är en arbetsmodell i egentlig mening, då tillämpningen anpassas lokalt och skiljer sig en del mellan kommunerna. När idén om brottspreventiv samverkan runt enskilda ungdomar i form av SSPF översatts i den lokala kontexten, visar det sig svårt att ringa in och definiera målgruppen för arbetet. Vilka är de ungdomar som blir aktuella för SSPF? Räcker det med skolproblem eller ska det vara mer allvarlig problematik hos den unge? Hur stor ska oron vara, räcker det med att vuxna bekymrar sig? Hur tidigt ska man "upptäcka"? Som på många andra punkter gällande SSPF-arbetet skiljer sig åsikterna om detta mellan SSPF-grupperna och ibland inom dessa. Det är enklare att enas kring åldersspannet vad gäller ungdomarna, även om det finns en spridning även här. I enkätsvaren ligger spridningen åldersmässigt från 10 upp till 25 år, men vanligast är att målgruppen är i tonåren, det vill säga 12-18. I Lillestad har man beskrivit målgruppen i ålder från barn i årskurs 5 upp till unga vuxna 25 år med utgångspunkt i möjligheten till så tidiga upptäckter som möjligt. I Mellanstad låg åldersspannet tidigare på 
6-20 år, men man har reviderat detta och numera är det 10-20 år som gäller. I Storstad är det vanligen ungdomar upp till och med årskurs 9 som kan bli aktuella, därefter menar man att det är svårt att jobba områdesbaserat, då ungdomarna börjar på gymnasieskolor i centrala staden, men man vill ge möjlighet upp till 18 år. Någon nedre gräns vill man inte ha i Storstadsdel:

... vi kan ju prata om barn och unga som går på lågstadiet och mellanstadiet också, för vi tycker det är viktigt att inte ha någon nedre gräns (koordinator Storstadsdel).

Men ansvarig polis i Storstad menar ändå att om polis lagmässigt ska vara med, ska det vara $\mathrm{i}$ ärenden från 12 år och uppåt.

Det saknas också konsensus gällande problembilden för de ungdomar som ska omfattas av SSPF. Några menar att det kan vara skäl att lyfta ett ärende till SSPF vid endast ökad skolfrånvaro, detta med hänvisning till att tidiga insatser är det enda verksamma. En polis illustrerar detta:

... och oron från skolan är oftast när eleverna börjar få för mycket frånvaro $i$ skolan och det är ju definitivt en varningssignal som är rätt att reagera på /.../men det är väl tanken att det ska vara så kan jag tycka, för det är då vi har chansen att med mindre insatser...då behöver vi kanske inte hamna i ett LVU om vi kan hamna rätt redan där då (Polis 1 Mellanstad).

Andra menar att oron kring ungdomen ska vara delad av alla samverkansparter och att det inte räcker med att exempelvis skolan känner oro.

Samordnande polis Storstad: Problembilden kan ju vara att man i skolan... det är en stökmåns, ställer till oreda, man har nåt...som inte stämmer. Samtidigt som polisen får att nu har den här killen begått ett brott.

I: Om bara skolan hör av sig, är det nog? 
Koordinator Storstad: Nej! För det ska vara, det ska röra... dessa - skola, socialtjänst, polis och fritid, det ska röra dom.

I de första gruppintervjuerna i Mellanstad från 2012 rådde en tydlig oenighet i någon grupp, där skola och polis ville använda SSPF vid begynnande skolproblem medan socialtjänsten menade att det skulle börja luta åt placering av den unge för att det skulle vara "värt" för SSPF. År 2014 uttrycker koordinatorn det så att det ska vara "dignitet" i ärendena, att den unge ska ha problem på flera områden - droger, kriminalitet, skolproblem, fritidsproblem:

... det ska finnas hög risk och en känd eller stor oro för kriminella handlingar... varför ska annars polisen vara med? (Koordinator Mellanstad)

En rektor menar att ofta har många andra insatser redan provats för den enskilde unge:

... jag menar det är ju ingen som kommer till ett SSPF där inte parterna gjort en massa jobb, har en massa tankar på jobb. Det är inte den första snön som kommer hit utan vi har jobbat jättemycket på våra kamrar och inte lyckats och känner att nu är verktygslådan tom (rektor Mellanstad).

I Mellanstad har man gått från en sorts förvirring kring definitionen av målgruppen i de första intervjuerna till en mer sammanhållen beskrivning, om än inte fullt ut.

Talet om tidiga insatser återkommer i många av intervjuerna, där är det svårt att uttolka vad som menas med tidigt med tanke på det ovan beskrivna. I Lillestad har man en ambition som handlar om tidiga upptäckter:

Och så resonerade vi oss fram till femte klass och att vi vill komma in tidigt, men inte hur tidigt som helst, men då kom vi fram till att i årskurs fem, där kan det börja hända saker och då kan vi kliva in tidigt kanske (brottsförebyggare Lillestad). 
I SSPF och andra preventionssammanhang har riskparadigmet tillsammans med betoning på skyddsfaktorer blivit det vanligaste sättet att tala om dessa ungdomar. Man vill minimera riskfaktorer och öka skyddsfaktorer runt den unge, detta återkommer i flera dokument och i intervjuer och enkät. För att kunna göra detta på ett bra sätt krävs dock just tidiga upptäckter, det ska inte ha gått för långt i en negativ utveckling.

En annan aspekt av målgruppen är att ungdomar som aktualiseras för SSPF ofta är pojkar. I Storstad svarade man snabbt "80-20" när de fick frågan om fördelning mellan pojkar och flickor, men:

\section{flickorna kommer starkt (ansvarig polis Storstad).}

Det kan vara så att det är svårare att definiera oron för de unga tjejer som ligger i riskzonen för att utveckla kriminalitet och/eller drogmissbruk. Detta är ingen ny upptäckt, utan många forskare har konstaterat att de flesta interventioner som samhället erbjuder ungdomar är utformade efter pojkars behov och att flickors och pojkars problem definieras olika. Flickors problem har historiskt sett definierats efter deras egenskaper, medan pojkars problem haft vidare gränser och fler förklaringar (Hamreby 2005, Söderberg, 2009).

Överlag är alltså målgruppen ospecificerad, varför behovet av samsyn kring den unge kan vara ett sätt att hantera detta.

\section{Den gemensamma bilden av den unge}

I interaktionen mellan aktörerna i denna samverkansform, liksom många andra, är den gemensamma bilden av mål och mening viktig. I SSPF framträder framför allt den gemensamma bilden av den unge som viktig. Det som huvudsakligen lägger en grund för detta, är enligt aktörerna möjligheten till informationsutbyte, som ges genom samtycket från vårdnadshavarna till informationsutbyte mellan parterna. Just denna möjlighet att byta information med varandra är något som återkommer i intervjuer och enkät som det mest framgångsrika med arbetssättet och egentligen en förutsättning för att SSPF ska fungera. Aktörerna skapar mening tillsammans vilket kan bidra till att interaktionen och det gemensamma agerandet underlättas (Weick 1995). 
Så - vad mer konkret medför denna möjlighet att fritt överföra information mellan parterna? Framför allt talas det i materialet om att samverkansparterna med hjälp av samtycket kan landa i "den gemensamma bilden" av den unge, vilket möjliggörs genom att man kan ta del av övrigas bilder och dela med sig av sin egen. Resultatet ska bli en samsyn på den unges problem och möjligen dess resurser samt vad som kan behövas för att stödja den unge och familjen till rätt väg.

Man fär fram en heltäckande och verklighetstrogen bild om den unges olika livsområden och därmed ett säkrare underlag för samverkan, åtgärder $\mathrm{mm}$ (koordinator $i$ enkätsvar)

En stor del av mötestiden går åt till detta skapande av den gemensamma bilden. I mina observationer vid SSPF-möten fördes noteringar gällande omfattningen av tid som upptogs av problembilden av den unge $i$ förhållande till motsvarande tid där man talade om mer positiva sidor eller om förslag till lösningar. Genomgående användes den största delen av tiden till att skapa den gemensamma risk / problembilden av den unge. Detta genom att aktörerna delgav varandra de orosbilder man hade gällande ungdomen, vilka problem som fanns på skolan, vad polisen kände till och så vidare. Diskussioner om lösningar samt kartläggning av den unges egna resurser och intressen gavs inte lika stort utrymme vid dessa möten. Därav gör jag tolkningen att den gemensamma bilden av den unge tenderar att vara den problematiska bilden snarare än bilden av en ung person med möjligheter och resurser runt sig.

Samtycket - så hanteras sekretessen

Framför allt polisen lyfter i intervjuerna möjligheten att genom samtycket kunna hantera sekretessen som den absolut viktigaste framgångsfaktorn för SSPF:

... det här med sekretessen att man inte ska kunna, man kommer ju ingenstans utan att bryta den. Även om det är för barnets bästa jämt och så kanske vi kan prata...(polis storstadsdel) 
Det har funnits ett hinder för samverkan och det hindret heter sekretess (polis 2 Mellanstad)

Detta resonemang bygger på den frustration som både polis och skola känt när man gjort orosanmälningar till socialtjänsten om en ung person, men sedan inte fått någon återkoppling och därmed inte haft kännedom om vilka eventuella interventioner som planeras från socialtjänsten eller ens om utredning har inletts. Sekretesslagstiftningen är strängast vad gäller socialtjänsten, även om övriga parter också har sekretessregler. Lagstiftningen om sekretess är till för den enskildes integritet och skydd för att inte känsliga uppgifter ska lämnas ut och hanteras ovarsamt. När det gäller barn och unga har vissa lättnader gjorts i lagstiftningen under senare år, till fördel för uppgiftslämnande mellan socialtjänst och polis (Lag 2014:633). Detta har sin grund i att sekretesslagstiftningen upplevts som ett problem vid brottsförebyggande samverkan mellan parterna (prop 2011/12:171).

Polisen är den part som framför allt betonar hur möjligheten att lätta på sekretessen gör att arbetet kan göra nya framsteg, men även respondenter från socialtjänsten ser vinster med samtycket:

... nu finns det möjlighet att jobba tillsammans i den här gruppen på ett annat sätt än tidigare om vi ska ta mötena på B-skolan som exempel, där det fanns behov av att nämna Kalle vid namn, om utredning var på gång så satt jag där och kunde inte säga nåt (representant för socialtjänsten Lillestad).

Informationsutbytet mellan aktörerna ska ske med respekt, detta betonas särskilt från socialtjänstens aktörer.

Det händer att föräldrar är tveksamma eller negativa till att skriva på samtycke. Det kan handla om oro för vad som ska sägas om familjen eller att man inte förstått riktigt vad det hela går ut på. När man inte får samtycke från vårdnadshavare skapar detta problem för SSPFsamarbetet:

Har vi inte samtycket blir det också problem, problemet blir ju då att det finns en förväntan att socialtjänsten ska komma och säga "ni behöver inte vara så oroliga, för vi 
har satt igång en insats" och så kan man inte det, det väcker jättemycket frustration faktiskt /.../ för vi vet att det är en ungdom i behov av stöd och hjälp och vi kan inte hjälpas åt i det (koordinator Storstadsdel).

I Lillestad har man vid en första kontakt med föräldrar mött positiva reaktioner gällande arbetssättet, men ändå haft svårt att sedan hämta in samtycket. Det ser ut som föräldrarna ångrat sig:

...man pratar om att ändra taktik lite grann där, att ha blanketten med sig från början, när man väl får hugg så...varsågod och skriv på då (polis Lillestad).

Argument för att förhindra en ung persons destruktiva utveckling dominerar i talet om SSPF i studien, liksom i de lagändringar som ägt rum $^{34}$ i brottsförebyggande syfte. Här framträder en skyddsaspekt gentemot den unge, vilket också framkommer i intervjuerna, tillsammans med betoning på vikten av tidiga upptäckter och tidiga insatser. I talet om samtycket blir spänningen mellan stöd och kontroll tydlig, detta sätt att underlätta informationsutbyte mellan aktörerna medför en ökad kontroll från samhällets nätverk (Cohen 1986), samtidigt som det underlättar möjligheterna att stoppa en destruktiv utveckling hos den unge. Ett syfte med arbetssättet i SSPF att på individnivå socialisera den unges beteende och främja en god utveckling, vilket har individen i fokus och stödjande inslag. Men samtidigt framträder behovet av samhällets kontroll över den unge tydligt i SSPF bland annat genom informationsutbytet. Sahlin (2000) menar att socialisation av individen och kontroll egentligen är oförenliga, då de bygger på olika människosyn. I detta vill man få med sig föräldrarna till den unge i en gemensam allians av goda krafter (Forkby 2006).

\footnotetext{
${ }^{34}$ I kapitel 3 beskrevs hur motsvarande lagändringar och skärpningar gällande ungdomskriminalitet skett även i Danmark och Norge.
} 


\section{Insatser och tänkta resultat i SSPF-arbetet}

Vad leder då SSPF-arbetet och alliansen mellan samhälle och familj till i form av insatser och stöd till den unge och familjen? En utgångspunkt $\mathrm{i}$ arbetet är snabb mobilisering av resurser runt den unge för att bryta en negativ utveckling. Som vi har sett arbetar man olika med denna process och en tolkning är att snabbhet definieras olika, framför allt hos polis respektive socialtjänst.

Av enkätsvaren framgår att föräldrastöd, förändring i skolsituationen och interventioner från socialtjänsten är de vanligaste insatserna som sker genom SSPF. Många gånger har socialtjänsten sedan tidigare kontakt med familjen och har kanske provat olika typer av stöd. På SSPF-mötet kan ny information tillkomma som gör att andra insatser prövas, även från socialtjänsten.

Det råder skillnad mellan kommunerna, men även inom kommunerna i vilken omfattning skolan uppfyller sin del av SSPF när det kommer till insatser. I Storstadsdel har man enats om att alla SSPF-ungdomar får samma insats, det är skolteamet som finns på högstadieskolorna och som jobbar med den unges hela situation. Insatsen är ett resultat av att man tidigare tyckte att det inte räckte med åtagandeplanen, för att vissa delar av det som bestämts tenderade att rinna ut i sanden, vilket illustreras med citatet:

Sen blev det så som det också kan vara, att det fanns personer som tog på sig olika uppdrag/.../, en av poliserna skulle vara stödperson /.../ stödkontakten med polisen började glesas ut ... det är väl alltid en risk i det också, att man tar på sig saker och sen, av olika anledningar så tappar man bort varandra lite för snabbt /.../skolteamet blev det som höll ihop kring den unge och faktiskt jobbade, blev det som fanns kvar när det andra började glesas ut (koordinator Storstadsdel).

Storstadsdel är den enda stadsdelen i Storstad som har just denna insats och inget av svaren i enkät eller övriga intervjuer tyder på att man någon 
annanstans har en specifik insats som erbjuds ungdom och familj $i$ $\mathrm{SSPF}^{35}$.

Som vi såg i föregående kapitel så stängs eleven av från skolan (gymnasiet) eller får begränsad hemundervisning om man påvisat ett positiv drogtest. Det gör att skolan har svårt i dessa fall att sätta in kraftfulla åtgärder som bidrar till förändring, då eleven är avgränsad från skolans kontext.

\section{Stöd till - och kontroll av - ungdomar}

Ett framträdande tema i studien är viljan att kontrollera ungdomarna för att förhindra vidare negativ utveckling och i detta också leda in den unge på mer konstruktiva banor. Spänningen mellan stöd och kontroll har återkommande diskuterats i uppsatsen. Kombinationen av detta "kontrollstöd" (Edvall Malm 2012) återfinns genomgående i materialet. Man talar om att polisen behöver veta vilka ungdomen umgås med för att få bättre koll på eventuella nätverk och störa dessa i sin utövning av det ena eller andra. Samtidigt uttalar poliserna i undersökningen upprepade gånger att det övergripande syftet för dem med SSPF inte är "att sätta dit ungdomen", utan att stödja och markera att "hit men inte längre".

Vi har en bild av ungdomarna utanför kontorstid, det är inte lika lätt att spegla upp en bild vare sig för föräldrar eller för skolpersonal eller för soc $i$ synnerhet om man har polis med (vid mötet, min anm.) som känner dem och vet vilka de umgås med /.../ så vill jag veta nåt om Kalle så kan jag få reda på det ganska bra och det är viktigt (polis Storstadsdel).

Samma polis beskriver en del av sin roll som att vara:

... nageln i ögat på den unge och ge en anledning till att inte ställa till det för sig, dom kan säga: "jag kan inte ta

\footnotetext{
${ }^{35}$ När slutmanus redigeras har Mellanstad tagit fram två insatser som stående kan erbjudas de ungdomar och föräldrar som blir erbjudna SSPF: ungdomscoach och föräldrastöd.
} 
den här spliffen ${ }^{36}$, för Tommy har sagt att han kommer att pissa av mig", ja och så får dom en anledning, det är lättare att säga nej.

Detta "kontrollstöd" (Edvall Malm 2012) i kombination med polisens roll som påminner om socialarbetarens vad gäller relationsskapande och stödjande ${ }^{37}$ gör att såväl institutionell spänning som isomorfism (Di Maggio \& Powell (1983) åter blir tydligt.

Om föräldern ingår i "de godas allians" som beskrivs vidare nedan, så är ungdomen sällan eller aldrig med där utan framställs som bärare av de problem som ska lösas. Överlag nämns inte ungdomarna som aktörer i någon större utsträckning $\mathrm{i}$ intervjuer, enkät eller observationer.

Stöd till (och fostran av) föräldrar - allians för att ge tillbaka föräldramandat
Ibland kan det finnas familjer där det är så otroligt stort professionellt nätverk runtomkring dem. Där alla vill och alla liksom gör jätte, jättemycket men det går åt helvete ändå, ibland känns det ju som att det är ju... det kan ju $v a$... dels kan det ju vara skrämmande men också tydligt att en del barn behöver så himla, himla mycket och hur ska du som stackars förälder reda ut det här? (koordinator Mellanstad)

Utöver den professionella alliansen framträder starkt i materialet en önskan om att stärka föräldrarna, att ingjuta hopp och en känsla av att inte vara ensamma - samhällets representanter bildar allians med föräldrarna.

Det är överlag svårt att hitta en tydlighet i materialet gällande vad SSPF-arbetet faktiskt leder till för de unga och deras familjer. Dock framträder en konsekvens av SSPF tydligt i nästan samtliga intervjuer med professionella (och i viss mån även i de intervjuer med föräldrar som genomförts):

\footnotetext{
${ }^{36}$ Cannabiscigarett

37 Detta beskrivs närmare i kapitel 7
} 
Men just känslan av att... det här uttrycket; det krävs en hel by för att fostra ett barn, att det kanske är det man skapar mer av när man hjälps åt på det här sättet. Och när föräldrarna börjar förstå det... man känner sig inte ensam på nåt vis (koordinator Storstad)

Här sker ett alliansbyggande mellan samhället och föräldrarna, vilket betyder att samhällets aktörer bildar allians med vårdnadshavarna för att skapa strukturer och kontroll runt den unge - en allians av goda krafter. Här ska föräldern känna stöd och få hjälp att kontrollera sitt barn:

... dom här nätverksmötena som vi har, då är alltid föräldrarna med /.../vi har kanske initierat en oro och sedan kanske knutit an föräldrarna. Som i min telefon, jag tror jag är uppe i 4000 telefonnummer, varav många är föräldrar och jag har avtal med många, ser jag Kalle klockan 11 ute sittande i bilen då ringer jag (polis Storstadsdel).

Till stor del handlar det om att föräldern ska känna ett stöd i att det är fler som mobiliserar runt den unge och att man inte är ensam med sin oro. Man ska också få stöd i att ta tillbaka ett tydligt föräldramandat:

/.../ och det är det jag tror att man som förälder kan få kraft, att man kan få ny kraft att jobba vidare med sitt barn, för att man ser att det finns andra som är med och hjälper till (Polis 1 Mellanstad)

Man vill i SSPF-arbetet ge föräldern kraft för att orka med sitt föräldraskap, men också ingjuta hopp om att det ska bli en bättre situation för den unge. Torbjörn Forkby har beskrivit detta som en allians för att installera hopp, vilken skapas i ett nätverksmöte runt en ung person (Forkby 2006). Detta kan också skapas i ett SSPF-möte, som på ett sätt kan sägas vara ett nätverksmöte. Till det andra mötet runt en ungdom är vanligtvis föräldrar och ungdom inbjudna, tillsammans med de aktörer som känner den enskilde unge och kan tänkas bidra med något för framtiden. Under detta möte talas om den oro som finns från alla håll, men syftet är också att se framåt och hitta nya möjligheter och resurser både i och utanför nätverket. 


\section{Ojämlik allians}

Alliansen mellan samhällets representanter och föräldrarna är dock inte alltid sådan att parterna är likvärdiga, utan det handlar även om att samhället ska stärka föräldrarna i sitt föräldraskap, ge föräldrastöd. Ibland kan detta ha formen av en sorts fostran riktad till föräldrarna:

Jamen till exempel som att lära föräldrarna att du måste ha tider för ditt barn ... hur mycket pengar ska han få $i$ fickpeng...det är jättemycket föräldrastöd, det är det som är bästa medicinen (samordnande polis Storstad)

Jag tror att på nåt sätt så tar en förälder väldigt på allvar när dom ser ... dom ser alltså möjligheten här ... att polisen som är ute och far omkring kan se mitt barn om det är i fara /.../ så där tror jag att som förälder om man har den förmågan kanske skärper sig och tänker till lite (representant för skolan, Mellanstad).

En maktobalans framträder, där samhällets representanter $i$ alliansen med föräldrar vill vara stödjande men också uppfostrande, även gentemot föräldrar. Likväl som i den professionella alliansen uppträder maktasymmetrier i samhällets allians med föräldrarna (Forkby 2005). I alliansen av goda krafter och den mobilisering som ska bli ett resultat av SSPF dominerar några aktörer mer än andra. Föräldrarna blir föremål för massivt stöd, de ska inte vara ensamma med problemen runt sitt barn. Tillsammans med de övriga som ingår i alliansen vill man ingjuta hopp i föräldrarna och hjälpa dem att få "tillbaka föräldramandatet". Detta kan tolkas som en form av empowerment (Askheim \& Starrin 2007), att uppmärksamma och stärka de resurser som föräldrarna har. Dock kan det samtidigt bli en form av maktutövning, då en relation mellan klient och myndighetsutövare aldrig kan bli jämlik (Järvinen 2002) För att koppla till tidigare resonemang så framträder återigen spänningen mellan stöd och kontroll här, även gällande föräldrar. Detta gäller i ännu högre grad de ungdomar, som ändå är de som är i fokus i SSPF. De ungdomar som erbjuds SSPF i de undersökta kommunerna har inte varit delaktiga i samtyckesprocessen och ingår inte i de allianser som bildas. 


\section{Sammanfattning och reflektion}

Den gemensamma bilden av den unge som skapar samsyn i arbetet framstår som den största framgångsfaktorn för parterna. Härigenom skapas den professionella alliansen och görs möjligt genom samtycket till informationsutbyte. Stödet till föräldrarna som skapas genom alliansbyggande mellan samhällets representanter och föräldrarna är det som i materialet framträder som framgången med SSPF. Detta ska i sin tur leda till att förutsättningarna för den unges framtid stärks genom de gemensamma kraftansträngningar som görs i alliansen. Här blir bilden dock otydligare. I SSPF-idén ingår att uppföljning ska ske av de planer och insatser som SSPF erbjuder den unge och familjen. Det råder osäkerhet bland respondenterna när frågan om uppföljning kommer upp:

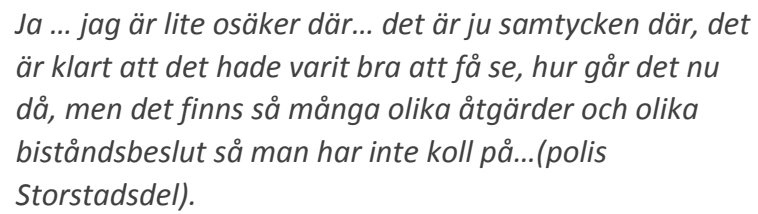

Det framkommer i några intervjuer att man har personlig kännedom om hur det gått för de ungdomar som erbjudits SSPF, någon ungdom har bett en polis vara referens när man söker jobb. Men det talas också om att tyvärr "fortsatte utförsbacken" för den eller den ungdomen. Någon systematisk uppföljning av SSPF gällande detta har ännu inte gjorts på något håll. Endast Storstadsdel har en specifik insats som alla ungdomar $\mathrm{i}$ SSPF erbjuds, nämligen skolteamet.

I detta kapitel har de resultat som rör interaktionen mellan SSPFaktörerna och familjen redovisats. Perspektivet har varit de professionellas och deras syn på målgrupp, samtycke och vad SSPF kan göra för skillnad för dem det berör - de unga och familjen. 


\section{Vision med svårigheter}

Denna studie bidrar till kunskapen om hur brottspreventiv samverkan på individnivå ordnas och diskuteras och hur framväxten av den kan förklaras och förstås. Med hjälp av nyinstitutionell teoribildning studeras idén och dess resa från nationell till lokal nivå samt de tolkningar och omtolkningar som sker. Studiens syfte är att beskriva och analysera individriktad brottsprevention i form av SSPF som idé och praktik.

Frågeställningarnas fokus var hur denna form av samverkan vuxit fram och motiverats, hur de organisatoriska villkoren ser ut och hur samverkansparterna upplever SSPF samt hur interaktionen mellan professionella och familj beskrivs av aktörerna.

Genom studien vill jag förstå hur fenomenet och idén om brottspreventiv samverkan runt individer vuxit fram i en samhällelig kontext, men också hur SSPF i praktiken fungerar och upplevs i den lokala kontexten när idén nått den lokala nivån. Studien är byggd utifrån tre fokusområden, vilka illustreras av figur 1 (policy/struktur; organisation/profession och praktik/familj). Dessa tre fokusområden har ibland visat sig vara svåra att hålla isär, de vävs samman av och till och skiljs åt igen, vilket bidrar till en komplex bild av SSPF som fenomen.

I detta avslutande kapitel ska jag återkoppla till studiens frågeställningar och lyfta fram ett antal centrala faktorer som påverkar ett arbetssätt som SSPF. De områden jag särskilt valt att lyfta är:

- SSPF som ett svar på en utveckling av brottsprevention som hör samman med samhällsutvecklingen i stort.

- Hur ska SSPF definieras?

- I SSPF-samverkan skapas allianser mellan professionella, men också mellan samhälle och familj. I de professionella allianserna uppstår ibland rollförvirring.

- Den professionella alliansen i SSPF är beroende av hur sekretessen hanteras.

Jag vill också avslutningsvis diskutera resultaten av arbetsformen SSPF, det vill säga; vad kan studien säga om vad arbetet leder till?

Inledningsvis vill jag belysa samhällsutvecklingens betydelse för SSPF. 


\section{Samhället och brottspreventionen}

Studien visar att SSPF och liknande brottspreventiva arbetsformer runt enskilda ungdomar förstås genom att sättas i ett större sammanhang. I detta sammanhang synliggörs hur brottspreventionens utveckling hänger ihop med hur välfärdssamhället omdanats de senaste decennierna. Detta har bland annat medfört att strukturella förklaringar och åtgärder gällande brottslighet fått stå tillbaka för en mer kontrollerande och åtgärdande diskurs. Ett alltmer individualiserat samhälle tillsammans med en strävan efter att öka effektiviteten i organisationer har medverkat till denna utveckling. Till detta kan resonemanget om komplexiteten i utvecklingen mot kontroll och hårdare tag kopplas. Den allmänna synen på brott har genomgått stora förändringar, vilket i sin tur påverkar brottspreventionen på så vis att långsiktiga strategier för att förebygga brott, liksom orsaksförklaringar blir ointressanta för såväl forskare som medborgare och politiker (Balvig 2004). Polisens roll har blivit allt viktigare $\mathrm{i}$ individriktad brottsprevention och hur polisen initierar och driver på arbetet och påverkar diskursen, exempelvis talet om sekretessen som en hindrande faktor i samverkan framträder tydligt.

Tidiga upptäckter av barn och ungdomar i riskzon är honnörsord och nätet för att upptäcka och fånga in dessa unga vidgas alltmer (Cohen 1985, Kelly 2012). Utvecklingen inom brottspreventionen som strävar mot snabba åtgärder i stället för att invänta långsiktiga effekter av inkludering och välfärdspolitiska åtgärder är också framträdande. På så vis styrs brottspreventionen bort från att vara en del av den generella välfärdspolitiken till att passa in i det rådande paradigmet, det nyliberala om man så vill och tenderar att alltmer höra hemma inom kriminalpolitiken. I denna strävan ses sekretessen som ett hinder för att nå framgång $\mathrm{i}$ arbetet och lättnader i sekretesslagstiftningen samt verktyg för att underlätta informationsutbyte mellan myndigheter blir allt vanligare. SSPF kan ses som en pusselbit i denna utveckling, liksom andra brottspreventiva arbetsmodeller som riktas mot individer.

Det andra området jag valt att lyfta handlar mer konkret om vad SSPF egentligen är; metod, modell eller arbetssätt? Hur man väljer att beskriva arbetet är viktigt för hur fortsatt utveckling av denna typ av arbete ska diskuteras. 


\section{Vad är SSPF?}

Visionen om SSPF, de ambitioner och tänkta resultat som det talas om i studien handlar om ett effektivare, snabbare och mer gemensamt agerande från samhällets aktörer. Detta ska göra att unga i riskzonen upptäcks tidigare och får snabbare insatser och detta sker genom mobiliserande av det Forkby $(2005,2006)$ kallar goda krafter runt den unge. Visionen om SSPF handlar vidare om att unga personer i risk för kriminalitet och/eller missbruk genom synergieffekter av samlade goda krafter snabbt ska komma till insikt och hjälpas in i en mer konstruktiv bana av sitt liv. Genom informationsutbytet ska långa handläggningstider och alltför sena insatser vara ett minne blott.

Även om jag till och från i texten valt att kalla SSPF för en brottspreventiv samverkansmodell är inte SSPF en modell i egentlig mening, eftersom såväl målgrupp som arbetssätt och insatser skiljer sig beroende på hur den lokala översättningen av idén om SSPF ser ut. Det finns ingen manual eller särskild mall för arbetet utan den lokala anpassningen är tydlig, även om vissa gemensamma drag givetvis finns även gällande processen med SSPF, som exempelvis organiseringen med styrgrupp och arbetsgrupp. Gemensamt för kommunerna är också inhämtande av samtycke till informationsutbyte, som är centralt och anses vara en förutsättning för arbetet. Utöver detta finns inga särskilda verktyg för bedömning eller uppföljning. Dessa resultat överensstämmer med den utvärdering av implementeringen av SSPF i Göteborgs stadsdelar som nyligen publicerades (Turner m fl. 2015), där man fann att SSPF implementerats olika och att arbetssättet tillämpades på varierande sätt i stadsdelarna. Det som identifierades som gemensamt i utvärderingen var just strukturen med styrgrupper och arbetsgrupper samt samtycket.

Den lokala översättningen av idén med brottspreventiv samverkan på individnivå gör alltså att SSPF i praktiken används på olika sätt i kommunerna och det blir tveksamt att kalla arbetet för en modell. Implementeringen, eller de försök till implementering som gjorts i kommunerna har fallit olika ut och det handlingsutrymme (Lipsky 2010, Svensson K. m fl. 2008) som aktörerna har lokalt ger förklaringar till detta. Handlingsutrymmet för de enskilda aktörerna är begränsat och 
påverkas av strukturella och organisatoriska faktorer, men ger ändå möjlighet att anpassa SSPF utifrån de lokala behov som finns och som identifieras av aktörerna.

Det finns även en annan aspekt av SSPF; i strävan efter att på ett bättre sätt än tidigare ingripa och förhindra en ung persons negativa utveckling har samhällets aktörer sökt efter mer framgångsrika sätt att arbeta, där har den här typen av samverkan har vuxit fram. Sahlin (2000) beskriver detta som effektivisering av institutioner, där strävan är att underlätta kontroll över den enskilde men ambitionen har också varit att göra arbetet mer stringent och framgångsrikt.

Svaret på frågan: vad är SSPF? kommer snarare att handla om vad SSPF inte är: det är inte en arbetsmetod och inte heller en tydlig arbetsmodell även om vissa gemensamma nämnare gällande struktur finns i de olika kommunerna. Det som utkristalliseras är ett nyare arbetssätt för arbetet mot ungdomskriminalitet där samhällets aktörer har velat komma vidare i samverkansarbetet med nya verktyg. Detta utifrån en vision om effektivare och snabbare reaktioner och insatser till unga $i$ risk för kriminalitet och/eller missbruk och där har SSPF och liknande samverkansformer runt målgruppen blivit ett resultat av den strävan. Framväxten av SSPF var som tidigare nämnts en pusselbit som passade in i den övriga samhälleliga utvecklingen.

Det tredje området jag lyfter handlar om själva samverkan, såväl dess roll i välfärdssamhället som specifikt i SSPF och de allianser som skapas i arbetet.

\section{Självklar samverkan...}

Det kan tyckas att samverkan idag är en självklar framgångsfaktor i socialt arbete och att detta sällan ifrågasätts utan i stället styrs av lagstiftning. Dock finns ett antal forskare som på senare tid har problematiserat självklarheten i framgångssagan med samverkan. Man lyfter fram bland annat risken för att samverkan blir ett självändamål och tar mycket tid i anspråk (Axelsson \& Bihari Axelsson 2007, Bergmark \& Lundström 2008), att det finns risk för att "glömma" brukarens del i samverkan och även risk för att den enskilde känner sig extra kontrollerad och övervakad (Willumsen 2007). 
I den allmänna diskussionen förekommer inte särskilt mycket problematiserande av samverkan och att ifrågasätta samverkan kan vara som att "svära i kyrkan". Talet om SSPF i studien handlar mycket om vinsterna med samverkan, om stärkta relationer mellan samverkansparterna, men också en del om frustration och spänning mellan såväl aktörer som institutionella logiker. Polisen vill se snabba insatser och socialtjänsten kan inte alltid leva upp till detta, då exempelvis en utredning kan pågå.

Detta problematiserande bör göras oftare och kanske är det så att samverkan ska övervägas noga gällande dess syfte och resultat i varje specifikt fall och inte ses som en självklar väg till framgång i socialt arbete och annat välfärdsarbete.

I fallet med SSPF framträder aktörernas roller i samverkan som särskilt intressanta och då framför allt de roller som innehas av polis och socialtjänst. Detta för att det blir tydligt att relationen dem emellan rör sig mellan spänning och likriktning och ibland till och med tangerar rollbyte, vilket ska diskuteras i nästa stycke.

\section{Dans i otakt}

När brottspreventionen rör sig alltmer mot kontroll uppstår nya förhållanden i relationen mellan aktörerna samtidigt som rollerna kan komma att delvis förändras, preventionsarbetet arbetet hamnar i en spänningssituation mellan stöd och kontroll (Edvall Malm 2012, Johansson, S. 2011a). I samverkan mellan de fyra olika institutionerna i SSPF medför detta också spänning eftersom grundlogikerna för de olika aktörerna skiljer sig (Johansson, S. 2011a, 2011 b). De olika aktörerna har dessutom olika lagstiftning att följa samt skilda huvuduppdrag att förhålla sig till. I studien framkom att denna spänning kan uppstå i också i SSPF-arbetet, det ser här ut som polisens logik dominerar och socialtjänsten står tillbaka eller anpassar sig, medan skolan och fritidssektorn har en mer passiv roll på flera håll. Spänningen blir än mer påtaglig i mötet och samarbetet mellan socialtjänst och polis. Det är också polisen som initierat och ofta driver på det brottspreventiva samarbetet och samverkansöverenskommelserna, det kan uttryckas som att polisen bjuder upp kommunerna till en brottsförebyggande dans och kommunerna kan få svårt att hålla takten. 
En annan sida av relationen mellan socialtjänst och polis i SSPF är att det uppstår likriktning - isomorfism (Di Maggio \& Powell 1982) - då exempelvis polisens roll ibland är mer av socialarbetarens och då socialtjänsten eller skolan talar om vinsterna av stärkt kontroll runt den unge. Den dubbla rollen socialarbetaren kan ha, där spänningen mellan stöd och kontroll uttalas som en svårighet återkommer i forskningen. I samarbetet runt unga mellan polis och socialtjänst, blandas de två logikerna och hamnar i en gemensam institutionell logik - "kontrollstöd" (Edvall Malm 2012). Det betyder att även polisen rör sig ur sin logik mot en mer stödjande behandlingslogik emellanåt. Detta är också något som framträder tydligt också i min studie. Socialtjänstens roll framstår i studien emellanåt som något otydlig, i stället framträder polisens roll ibland som iklädd socialarbetarens.

Detta, tillsammans med den frustration som ibland uttrycks från polisens sida gällande socialtjänstens tröghet, gör att frågan om socialtjänstens eventuella tillkortakommanden gällande det preventiva arbetet måste ställas. Är det så att socialtjänsten trätt tillbaka på den preventiva arenan och öppnat upp för andra att ikläda sig rollen som socialarbetare? Det är ju också socialtjänstens strikta sekretess som har setts som hindret för framgångsrik samverkan och som nu via lättnader i lagstiftning och samtycken kan "hanteras". Polisens förebyggande arbete bland unga påminner på sina håll om det som traditionellt hört till socialtjänstens uppsökande fältarbete. Polisen har, där detta inte längre finns, identifierat ett tomrum som man i vissa fall själva försöker fylla.

Trots att jag mest diskuterat polis och socialtjänst och dess roller ingår fyra organisationer och dess aktörer i SSPF. Polisens roll i arbetet blir tydlig som den som driver på arbetet. I utvärderingen av Göteborgs arbete med SSPF (FoU i väst/GR 2015) var det också polisen som var mest positiv till arbetsformen. Däremot framstod fritidssektorn som den mest otydliga och osäkra parten i arbetet, vilket också stämmer med resultaten i denna studie, där fritidssektorn beskrivs av övriga parter som mycket viktig, men inte tar någon större plats i samverkan. Skolan beskrivs som den viktigaste arenan, men framträder i min studie som ambivalent, då beslutsmandat och ambitioner skiljer sig kraftigt åt. En ojämlikhet mellan aktörerna framträder, vilket i sig inte är ovanligt $i$ samverkan - maktförhållanden existerar även här. Olika status ger 
professionerna olika tolkningsföreträde, här ser fritidssektorn ut att ha den lägsta statusen och blir därför allra mest otydlig.

Det ovan beskrivna är en sida av samverkan i SSPF, som visar på vissa svårigheter. Men i studien växer också bilden av alliansskapandet fram, där samsyn om den unge och tron på framgång förenar parterna och dessutom stärker stödet till föräldrarna.

\section{Alliansskapande}

Studien visar att de upplevda fördelarna och vinsterna med SSPF trots allt dominerar bland aktörerna. Hanteringen av sekretessen ses som en förutsättning för framgång, detta i sin tur medför att den gemensamma bilden, samsynen om den unge, växer fram och detta utgör grunden för det fortsatta arbetet. Genom detta skapas en allians mellan de professionella, en gemensam mening och vilja som genom handlingskraft ska stärka den unges förutsättningar till ett bättre liv. Den professionella alliansen byggs kring denna gemensamma bild av den unge.

Ett antal förutsättningar påverkar dock möjligheten till detta alliansskapande. "Vi-känslan" framträder som en annan meningsskapande del i arbetet, från den tätt samarbetade gruppen i Lillestad, till SSPF-gruppen i Storstadsdel. Det skapar trygghet och kontinuitet att man känner dem man ska samverka med. Danermark (2000) diskuterar begreppet personkemi i samverkanssammanhang och menar att alltför stor vikt läggs vid detta i stället för att fokusera på funktioner. Ändå visar studien tydligt på vikten av relationer i samverkan och att byte av personer i en SSPF-grupp kan skapa obalans och oro i arbetet, likväl som större omorganisationer på förvaltningsnivå. Drömmen om framgång i arbetet grusas av denna instabilitet. De organisatoriska förutsättningarna för samverkan av denna typ är grundläggande om arbetet ska bli framgångsrikt. Arbetet är beroende av prioritering och ett tydligt mandat till dem som ingår i samverkan. Med tanke på svårigheter i implementering samt den skörhet som tydliggörs vid instabilitet bör man överväga vilka organisatoriska förutsättningar som råder i den specifika kommunen innan man drar igång brottspreventiv samverkan på individnivå.

Hur kan då denna specifika samverkan kategoriseras? På en nivå är alliansen mellan parterna stark, samsynen, den gemensamma bilden av 
den unge förenar och syftet med SSPF är gemensamt för parterna. Men vid tillämpning av Horwath och Morrisons modell för samverkan handlar SSPF fortfarande mycket om informationsutbyte mellan parterna, om än med ett gemensamt syfte. Dock finns gemensamma avtal framtagna, åtminstone på övergripande nivå i kommunerna och det finns skrivna planer för SSPF, vilket höjer nivån på samverkan enligt modellen (Horwath \& Morrison 2007).

De professionellas allians övergår ibland till - eller kompletteras med samhällets allians med föräldrarna, här ska föräldrar stärkas och få stöd i sitt fortsatta föräldraskap, ofta genom att kontrollen av den unge stärks och fler aktörer deltar i detta. En allians av goda krafter skapas (Forkby 2006). Föräldrastödet kan tangera föräldrafostran, samhället behöver lära föräldern att bättre ta sitt ansvar, återigen handlar det om samhällets styrning av individen (Johansson, K. 2012). Men framför allt träder ambitionen om att inge förälder och ungdom hopp om en bättre framtid, att mobilisera de resurser som finns hos och runt den unge fram, vilket ligger i linje med Forkby (2005) och Börjeson (2010). I studien lyfts föräldrastödet fram av aktörerna som ett viktigt resultat av SSPF-arbetet. Denna allians mellan samhälle och förälder syftar till ökad kontroll över den unge i första steget, men kan också bidra till att oroliga föräldrar avlastas lite av oron och ansvaret för den unges väl och ve. Här återkommer kluvenheten och förhållandet mellan stöd och kontroll, vilket i detta fall inte behöver vara problematiskt med det bör medvetandegöras.

Det som framträder starkast som nyckeln till ett framgångsrikt arbete i SSPF är talet om samtycket till informationsutbyte, vilket gör alliansskapandet möjligt. Detta behöver diskuteras särskilt.

\section{Nyckeln till framgång}

Studiens resultat visar att talet om sekretessen- eller snarare möjligheten att hantera den är centralt. Verktyget samtycke till informationsutbyte ses som själva nyckeln till framgång för ett arbetssätt som SSPF. När aktörerna öppet kan diskutera den unge och de problem som finns runt denne, är vägen öppen till att hitta snabba insatser där alla parter tar sitt ansvar. Ambitionerna är höga och likaså förväntningarna på att ett 
arbetssätt som SSPF ska göra skillnad på ett sätt som inte varit möjligt tidigare. Som ett led i utvecklingen mot en ökad kontroll och strävan efter effektivare arbetssätt runt målgruppen har frågan om sekretessen drivits. Samtycke till informationsutbyte har blivit det verktyg som underlättar och egentligen är nödvändigt för att visionen om SSPF ska uppfyllas. Detta kan ses som ett medel för att uppnå målen med arbetet, men framstår ibland i materialet som målet i sig. Lättnader i sekretessen är en del av - eller en följd av - utvecklingen inom brottspreventivt arbete och egentligen av samhällsutvecklingen utifrån tidigare resonemang om individualisering och ökad kontroll.

Med detta menar jag att informationsutbytet lyfts fram som grunden för framgång och att ökad kännedom om den enskilde ungdomen i sig med automatik skulle leda till bättre insatser. Det kan ifrågasättas om målet alltid helgar medlen om måluppfyllelsen är så pass oklar som den är i detta arbete. Frågan om hur arbetet gagnar den unge kan behöva ställas. Därför kommer avslutningsvis ett resonemang om framgång och behållning av arbetet föras.

\section{Resultat av SSPF?}

I talet om SSPF framställs arbetssättet som banbrytande i och med hanteringen av sekretessen och de möjligheter till intensifierad samverkan runt de unga individerna som detta ger. Det är dock svårt att finna tydlighet i vad SSPF- arbetet egentligen leder till, vad blir egentligen skillnaden för den enskilde ungdomen och familjen efter att den unge blivit ett "ärende" för SSPF? Alltså; vad blir skillnaden för den unge jämfört med en mer konventionell gång med orosanmälan till socialtjänsten, utredning och insatser från socialtjänst och skola? Här blir också den upplevda skillnaden för den unge och familjen vad gäller förändring jämfört med tiden före SSPF viktig. Denna studie ger inte några tydliga svar på någon av dessa frågor, däremot sätter den ljuset på de antaganden om SSPF och liknande brottspreventiv samverkan på individnivå som finns i samhället och i själva SSPF-praktiken.

I det inledande kapitlet beskrevs detta med hjälp av en typ av programlogik där de antaganden vad gällde målgrupp, insatser och resultat för SSPF som framkommit redovisades. 
Tabell 5: Antaganden om SSPF-modellen

\begin{tabular}{|l|l|l|}
\hline Tänkt målgrupp & Tänkta insatser & Tänkta resultat \\
\hline $\begin{array}{l}\text { Unga individer där oro för } \\
\text { begynnande kriminalitet } \\
\text { och /eller missbruk } \\
\text { föreligger och de vanliga } \\
\text { stödsystemen inte räcker } \\
\text { till. }\end{array}$ & $\begin{array}{l}\text { Snabba och intensiva } \\
\text { insatser från var och en av } \\
\text { de samverkande } \\
\text { aktörerna. Insatser och } \\
\text { ansvar görs upp i en } \\
\text { handlingsplan vid SSPF- } \\
\text { möte. }\end{array}$ & $\begin{array}{l}\text { Tack vare samverkansvinster } \\
\text { och snabb aktion från de } \\
\text { olika aktörerna stoppas den } \\
\text { unges destruktiva utveckling } \\
\text { och alternativa } \\
\text { utvecklingsvägar har } \\
\text { erbjudits den unge och } \\
\text { familjen. }\end{array}$ \\
\hline
\end{tabular}

För att återknyta till de antaganden som finns om SSPF försöker jag nedan tydliggöra det jag funnit i studien som kan beskriva hur resultaten förhåller sig till de antaganden som finns om SSPF. Vi vet naturligtvis ingenting om eventuella långsiktiga effekter av SSPF utan kan endast utifrån studiens material göra en enkel uppföljning, vilken syftar till att om möjligt tydliggöra de något luddiga konturer som finns runt SSPF. Jämfört med de inledande antaganden om SSPF gällande målgrupp, insatser och resultat som vi funnit, visar studiens resultat att bruksteorin inte stämmer helt överens med den anammande teorin (Argyris \& Schön 1977). De tidiga antaganden som finns om SSPF skiljer sig en del mot hur SSPF-arbetet faller ut i studien.

Tabell 6: Studiens resultat i förhållande till antaganden om SSPF

\begin{tabular}{|c|c|c|}
\hline Reell målgrupp & Reella insatser & Reella resultat \\
\hline $\begin{array}{l}\text { Unga individer med stor } \\
\text { variation vad gäller ålder } \\
\text { och problembild. } \\
\text { Konsensus råder ej vad } \\
\text { gäller hur tidigt i en } \\
\text { negativ utveckling den } \\
\text { unge blir aktuell för } \\
\text { SSPF. } \\
\text { Mestadels pojkar. }\end{array}$ & $\begin{array}{l}\text { Föräldrastöd genom } \\
\text { alliansbildning - en allians av } \\
\text { goda krafter. } \\
\text { Respektive organisation ser över } \\
\text { sina möjliga bidrag till } \\
\text { handlingsplan/åtagandeplan för } \\
\text { den specifike unge. } \\
\text { Skolteam i Storstadsdel } \\
\text { Stor variation mellan kommuner }\end{array}$ & $\begin{array}{l}\text { Gemensam bild av den } \\
\text { unge bland SSPF- } \\
\text { aktörerna, görs möjlig } \\
\text { via samtycke. } \\
\text { Ökad kontroll av den } \\
\text { unge - net-widening. } \\
\text { Föräldrar fått stöd i sitt } \\
\text { föräldraskap genom } \\
\text { alliansen med SSPF- } \\
\text { aktörerna. }\end{array}$ \\
\hline
\end{tabular}


Vad blir då nyttan med ett arbetssätt som SSPF utöver det som beskrivits? Är arbetssättet ett självändamål för att få mer information om vissa ungdomar och intensifiera samverkan mellan parterna eller leder arbetet också till en reell förändring för ungdom och familj? Eller är det bara ett sätt för samhället att genom ökad kontroll kunna påverka ungdomar och föräldrar?

Resultaten av SSPF-arbetet må vara otydliga och inte något som klargörs i denna studie, för detta krävs en effektstudie av något slag. Däremot kan studien säga en del om betydelsen av SSPF som en vision för framgång för de samverkande parterna. Studien kan trots allt visa på resultat som pekar mot förändring och påverkan. Resultaten visar bland annat att de professionella främst betonar stödet till den unges vårdnadshavare som något positivt som kommer ur SSPF. Det tar som vi sett ibland formen av fostran, där föräldern ska lära sig att ta ett större ansvar för sitt barn. Men mer vanligt är att alliansbildning mellan samhällets representanter och föräldrarna sker, ofta i formen av stärkt kontroll riktad mot den unge, som befinner sig utanför alliansen (jfr Sahlin 1992, Forkby 2006). I alliansen av goda krafter ska hopp om möjligheter framåt skapas för familjen och för den unge. Det är också här förslag till insatser från de olika parterna, gärna innovativa sådana, ska resultera i en gemensam handlingsplan för den unge. Om utfallet av arbetet blir bra eller inte avgörs i den lokala praktiken där aktörerna förvisso är påverkade av samhällsutveckling och den egna institutionens logik, men också har ett handlingsutrymme att påverka själva tillämpandet av arbetssättet. Detta får, som vi sett, till följd att SSPF fungerar olika från kommun till kommun. Frågan är om det behöver vara negativt, det kanske är så att de lokala förutsättningar och det handlingsutrymme som finns i varje lokal kontext måste få avgöra på vilket sätt man väljer att arbeta med SSPF och liknande modeller. Dock bör varje satsning av liknande slag redan i planeringsskedet innehålla en plan för hur uppföljning ska ske. Det finns ännu ingen forskning som stödjer denna typ av samverkan vad gäller effekter.

Med hänvisning till kluvenheten på flera punkter och kopplingen till den samhälleliga utvecklingen menar jag att fenomenet brottspreventiv samverkan kring unga individer är komplext, förståelsen är inte entydig. Klart är att SSPF är ett symptom på diskursen om ökad kontroll och 
samhällets skydd, samtidigt som det handlar om ett försök till ökad effektivitet för den enskilde unges bästa.

Tveklöst är det så att de samverkande parterna i kommunerna är positiva till SSPF och dess möjligheter. Ambitionsnivån ska inte ifrågasättas, däremot är det intressant att fundera kring hur den fortsatta utvecklingen av SSPF kommer att se ut de närmaste åren och vad de faktiska resultaten och nyttan av arbetet är när det kommer till de unga och deras familjer. Ytterst är det för dessa ungdomar som SSPF ska göra skillnad och vid alla typer av interventioner i människors liv bör frågan ställas: Vad är betydelsen av detta och hur vet vi om arbetet gör skillnad? 


\section{Referenser}

Ahlgren, Torbjörn (2014) Institutionalisering på hemmaplan. En idés resa i den sociala barnavården (doktorsavhandling). Linnéuniversitetet, Institutionen för socialt arbete.

Alexandersson, Karin (2006) Vilja, kunna, förstå: om implementering av systematisk dokumentation för verksambetsutveckling $i$ socialtjänsten (doktorsavhandling). Örebro universitet. Andershed, Henrik \& Andershed Anna-Karin(2010):

Ungdomsbrottslighet: Hur vanligt är det och vad beror det på? I: Andershed, Andershed \& Söderholm Carpelan (red) Ungdomar som begår brott. Vilka insatser fungerar? Stockholm: Gothia.

Andersson, Gunvor \& Swärd, Hans (2008) Etiska reflektioner I: Anna Meuwisse; Hans Swärd; Rosmari Eliasson-Lappalainen \& Katarina Jacobsson (red.) Forskningsmetodik för socialvetare. Stockholm: Natur \& Kultur

Andersson, Gunvor \& Sallnäs, Marie (2012) Social barnavård och barns utsatthet. I: Ingrid Höjer; Marie Sallnäs \& Yvonne Sjöblom (red) När sambället träder in - barn, föräldrar och social barnavård. Lund:

Studentlitteratur.

Andersson, Lena (2010) När strävan efter samsyn blir en kamp-

Meningsskapande och meningsgivande $i$ màngtydiga sammanhang

(doktorsavhandling). Linköpings Universitet

Andreasson, Ingela \& Asp-Onsjö, Lisa (2009). Talet om pojkar och flickor i behov av särskilt stöd. I A. Ahlberg (Red.), Specialpedagogisk forskning - en mångfasetterad utmaning. (s. 35-58). Lund: Studentlitteratur AB.

Argyris, Chris \& Schön, Donald A. (1977) Theory in practice. Increasing professional effectiveness. San Fransisco: Josey Bass Publishers.

Askheim, Ole Petter \& Starrin, Bengt (2007). Empowerment i teori och praktik. Malmö. Gleerups.

Axelsson, Runo \& Bihari Axelsson, Susanna (2007)(red) Folkhälsa i samverkan mellan professioner, organisationer och sambällssektorer. Polen:

Studentlitteratur.

Baker, Kerry \& Sutherland, Alex (2009) MultiAgency Public Protection Arrangements and Youth Justice. Bristol: The Policy press. 
Balvig, Flemming (2004) When law and order returned to Denmark. Journal of Scandinavian studies in criminology and crime prevention. Vol 5, s. 167- 187.

Basic, Goran; Thelander, Joakim \& Åkerström, Malin (2009) Vårdkedja för ungdomar eller professionella? En processutvärdering av projektet Motverka våld och gäng. Rapport. Statens institutionsstyrelse.

Bergmark, Åke \& Lundström, Tommy (2008) Resurser, personal och samverkan I socialt arbete. I: Åke Bergmark; Tommy Lundström; Renate Minas \& Stefan Wiklund (red) Socialtjänsten $i$ blickfänget. Organisation resurser och insatser. Stockholm: Natur \& Kultur.

Bergnehr, Disa (2014) Att (sam)verka för barns hälsa och lärandet i mötet mellan socialtjänst och skola. En forskningsöversikt. Stockholms stad.

Blom, Björn \& Morén, Stefan (2007) Insatser och resultat $i$ socialt arbete. Polen: Studentlitteratur Blomqvist, Camilla (2012) Samarbete med förbinder - om samarbete mellan BUP, socialtjänst, skola och familj (doktorsavhandling). Göteborgs universitet, Institutionen för socialt arbete.

Boklund, Ann (1995) Olikheter som berikar - möjligheter och hinder $i$ samarbetet mellan socialtjänstens äldre- och handikappomsorg, barnomsorg samt individ- och familjeomsorg. Stockholms Universitet.

Braun, Virginia \& Clarke, Victoria (2006) Using thematic analysis in psychology. Qualitative research in psychology 2006; 3: s. 77-101.

Bryman, Alan (2002) Sambällsvetenskapliga metoder. Malmö: Liber Brottsförebyggande rådet (2006) Redovisning av uppdraget att redovisa vilka samarbets- och arbetsformer som skapar förutsättningar för goda resultat $i$ det lokala brottsförebyggande arbetet. Stockholm.

Brottsförebyggande rådet (2011) Polisens strategiska brottsförebyggande arbete. Dnr Brå 2011/0029. Stockholm.

Brottsförebyggande rådet (2008) Barn som begår brott. Socialtjänstens och polisens åtgärder. BRÅ-rapport 2008/11 Stockholm:

Brottsförebyggande rådet, Rikspolisstyrelsen \& Sveriges kommuner och landsting (2010) Samverkan i lokalt brottsförebyggande arbete. Stockholm: Fritzes

Börjeson, Bengt (2010) Förstå socialt arbete. 2a uppl. Malmö: Liber förlag Cohen, Stanley (1985) Visions of social control: crime, punishment and classification. Camebridge: Polity Press 
Czarniawska, Barbara \& Joerges, Bernward (1996). Travels of ideas. I:

Barbara Czarniawska \& Guje Sevon (red.) Translating organizational change.

Berlin: Walter de Gruyter

Danermark, Berth (2000) Samverkan - bimmel eller belvete? Stockholm:

Gothia

Danermark, Berth (2004) Samverkan- en fråga om makt. Finland: WS

Bookwell

Danermark, Berth (2011) Samverkan: skola, socialtjänst och hälso-och sjukvård. I: Socialstyrelsen (2013) Samverka för barns bästa - en vägledning om barns behov av insatser frän flera aktörer. Stockholm: Socialstyrelsen.

Danermark, Berth \& Cullberg, Christian (1999) Samverkan - välfärdsstatens nya arbetsform. Lund: Studentlitteratur

Danermark, Berth; Germundsson, Per; Englund, Ulrika \& Lööf, Kicki (2007) Samverkan kring barn som far illa eller riskerar att fara illa. En formativ utvärdering av samverkan mellan skola, socialtjänst, polis och barn- och ungdomspsykiatri. Skolverket.

Danermark, Berth; Germundsson, Per; Englund, Ulrika \& Lööf, Kicki (2009) Utvärderarna i Örebro reflekterar. I: Skolverket (2009) Kraften av samverkan. Om samverkan kring barn och unga som far illa eller riskerar att fara illa. Stockholm: Fritzes

Det Kriminalpraeventive råd (2012) SSP - en guide til samarbejdet.

Köpenhamn.

Di Maggio, Paul J. \& Powell, Walter W. (1983) The iron cage reviseted: Intitutional isomorphism and collective rationality in organizational fields. American sociological review Vol.48, April, s. 147-160.

Edvall Malm, Disa (2012) Det socio-polisiära handlingsnätet. Samverkan mellan polis och socialtjänst kring ungas missbruk och kriminalitet (doktorsavhandling). Umeå Universitet, Institutionen för socialt arbete.

Ehn, Bily \& Löfgren, Orvar (1996) V ardagslivets etnologi. Reflektioner kring en kulturvetenskap. Stockholm: Natur \& Kultur

Estrada, Filip och Granath, Sven (2008): "Ungdomsbrottslighet" $i$

Brottsutvecklingen i Sverige fram till 2007. Brå-rapport 2008:23. Stockholm:

Brottsförebyggande rådet.

Ferrer-Wreder, Laura; Stattin, Håkan \& Cass Lorente, Carolyn (2005)

Framgångsrika preventionsprogram för barn och unga - en forskningsöversikt.

Stockholm: Gothia. 
Forkby, Torbjörn (2005) Ungdomsvård på hemmaplan. Ideerna, framväxten, praktiken (doktorsavhandling). Göteborgs universitet, Institutionen för socialt arbete.

Forkby, Torbjörn \& Larsen Theresa (2005). Katalysatormodellen I brottspreventiv samverkan. Utvärdering av Ung och Trygg $i$ Göteborgs första fas. FoU i Väst/GR

Forkby, Torbjörn (2006) Socialt nätverksarbete. Alliansbildning, makt och retorik. FoU i Väst/GR

Forkby, Torbjörn (2008) Gängrelaterat ungdomsarbete. En utvärdering av Ung och Trygg i Göteborg. FoU i Väst/GR.

Forkby, Torbjörn \& Liljeholm Hansson, Susanne (2011) Kampen för att bli någon. Bilder av förorten och riskefyllda utvecklingsvägar $i$ Göteborg. FoU Väst/GR.

Germundsson, Per (2010) Lärare, socialsekreterare och barn som far illa. Om sociala representationer och interprofessionell samverkan. Studies from the Swedish Institute for Disability research, 36. Örebro universitet. Garland, David (2001) The culture of control. Crime and social order in contemporary society. Oxford: Oxford university press.

Ginsberg. Liane \& Tregunno, Deborah (2005) New approaches to interprofessional education and collaborative practice: Lessons from the organizational change literature. Journal of interprofessional care. (May 2005) Supplement 1: s. 177-187

Grape, Ove (2006) Domänkonsensus eller domänkonflikt? I: Ove Grape; Björn Blom. \& Roine Johansson (red) Organisation och omvärldnyinstitutionell analys av människobehandlande organisationer. Lund:

Studentlitteratur.

Gundhus, Helene I; Egge, Marit; Strype, Jon \& Myhrer, T.or-Geir (2008): Modell for forebygging av kriminalitet? Evaluering av Lokale kriminalitetsforebyggende Tiltak (SLT). PHS Forskning 2008:4, Politihogskolen.

Hammersley, Martyn \& Atkinsson, Paul (2007) Etnography: principles in practice. London: Routledge.

Hamreby, Kerstin (2005) Flickor och pojkar i den sociala barnavairden. Föreställningar om kön och sociala problem under 1900-talet. Umeå Universitet, Institutionen för socialt arbete. 
Hasenfeldt, Yeskel (1983) Human Service Organizations. Michigan:

University of Michigan.

Hjelte, Jan; Brännström, Jan \& Engström, Christer (2010) Lokal evidens (Loke)! En modell för lokal uppföljning av kommunal öppen- och heldygnsvärd som riktar sig till personer med missbruks- och beroendeproblematik. Ett SKL-uppdrag. Umeå kommun: UFFE- Utvecklings- och fältforskningsenheten.

Hjelte, Jan; Westerberg, Kristina \& Svanevie, Kajsa (2014) En ljusnande framtid är vår? En utvärdering av Umeå kommuns satsning på ungdomsjobb mellan àren 2010-2013. Umeå kommun: UFFE - Utvecklings- och fältforskningsenheten.

Hollari, Solveig (2006) Arbetsformer för goda resultat $i$ brottsförebyggande arbete. Brottsförebyggande rådet.

Holme, Idar Magne \& Krohn Solvang, Bernt (2009)Forskningsmetodik: Om kvalitativa och kvantitativa metoder. Lund: Studentlitteratur.

Holstein, James. \& Gubrium, Jaber F. (1995) The active interview.

Thousand Oaks: Sage.

Horwath, Jan \& Morrison, Tony (2007) Collaboration, integration and change in children's services: Critical issues and key ingridients. Child abuse and neglect 31 s. 55-69

Huxham, Chris \& Vangen, Siv (2005) Managing to collaborate. The Theory and practice of collaborative advantadges. London. Routledge.

Johansson Kerstin (2014) Crime Prevention Cooperation in Sweden: A Regional Case Study. Journal of Scandinavian Studies in Criminology and Crime Prevention. Vol 15:2, s. 143-158.

Johansson, Kerstin (2012) Mellan stöd och kontroll. Prevention riktad mot föräldrar, barn och unga. I: Kenneth Petersson, Magnus Dahlstedt \& Birgitta Plymoth (red.) Fostran av framtidens medborgare. Normer och praktiker bortom välfärdsstaten. Lund: Sekel.

Johansson, Kerstin (2013) Kunskap, makt och styrning. I: Stig Linde. \& Kerstin Svensson (red) Förändringens entreprenörer och tröghetens agenter. Stockholm: Liber.

Johansson, Kerstin \& Henriksson, Lena red. (2013) Brottsprevention $i$ Östergötland - en kartläggning av aktiviteter och kunskapsläge. Linköpings Universitet. 
Johansson, Roine (1997) Organisationer emellan. Om förhandlingar, maket och handlingsutrymme. Lund: Studentlitteratur.

Johansson, Susanna (2011a) Rätt, makt och institutionell förändring. En kritisk analys av myndigheters samverkan $i$ barnahus (doktorsavhandling). Lunds Universitet, Rättssociologiska institutionen.

Johansson, Susanna (2011b) Juridifiering som institutionell förändring. Om mötet mellan straffrätt och socialrätt vid interorganisatorisk samverkan. Retfaerd, årgång 344 (135), s. 38-59.

Johansson, Susanna (2013) Samverkan som konflikt - om förhållandet mellan rättsliga strukturer och organisatoriskt handlande. I: Stig Linde \& Kerstin Svensson (red.) Förändringens entrepenörer och tröghetens agenter.

Människobehandlande organisationer ur ett nyinstutitionellt perspektiv. Stockholm: Liber.

Justitiedepartementet. Allas varrt ansvar. Ett nationellt brottsförebyggande program. Ds (1996:59). Stockholm

Justis -og politidepartementet (2008) Gode krefter. Kriminalitetsforebyggende bandlingsplan. 35 tilltak for okt trygghet. Oslo.

Järvinen, Margareta (2002) Mötet mellan klient och system. Om forskning i socialt arbete. Dansk sociologi vol.13 (2), s. 73-84

Kelly, Laura (2012) Representing and preventing youth crime and disorder: Intended and unintended consequences of targeted youth programmes in England. Youth justice 12 (2), s. 101-117

Kvale, Steinar \& Brinkman, Svend (2009) Den kvalitativa forskningsintervjun. Lund: Studentlitteratur.

Lab, Steven (2004) Crime prevention. Approaches, Practices and Evaluations $5^{\text {th }}$ ed. Anderson publishing: Bowling Green State University.

Larsson, Sam (2005) Kvalitativ metod - en introduktion. I: Sam Larsson John Lilja \& Katarina Mannheimer (red) Forskningsmetoder $i$ socialt arbete. Lund:

Studentlitteratur

Lindberg, Kerstin (2009) Samverkan. Malmö: Liber

Linde, Stig \& Svensson, Kerstin red(2013) Förändringens entreprenörer och tröghetens agenter. Människobehandlande organisationer ur ett nyinstutitionellt perspektiv. Stockholm: Liber

Lipsky, Michael (2010) Street-level bureaucrayy. Dilemmas of the individual in public services. New York: Russel Sage Foundation. 
Matland, Richard E. (1995) Synthesizing the implementation literature: The ambiguity-conflict model of policy implementation. Journal of public administration research and theory, 5 (2), 145-175.

Minkes, John; Hammersley, Richard \& Raynor, Peter (2005) Partnership in working with young offenders with substance misuse problems. The Howard Journal vol 44 (3), s. 254-268

Monk, David (2009) Promoting public protection in youth justice: challenges for policy and practice. I: Kerry Baker \& Alex Sutherland (red.) Multi-agency public protection arrangements and youth justice. Bristol: The policy press.

Nordiska rådet \& Brå (2000) Crime prevention in the Nordic context- the Nordic model. Brottsförebyggande rådet.

Oliver, P. (2010) The students guide to research ethics. Birkshire: Open university press.

Pamment, Nicholas (2010) Youth offending teams: a multi-agency success or system failure? I: Pycroft, A. \& Gough, D (red) Multi-agency working in criminal justice. Control and care in contemporary correctional practice. Bristol: The policy press Parton, Nigel (2005) "Every child matters": The shift to prevention whilst strengthening protection in childrens's services in England. Children and youth services rewiew 28, s. 976-992.

Patton, Michael Quinn (2002) Qualitative research and evaluation methods Thousand oaks, California: Sage

Persson, Anders \& Svensson, Kerstin (2005) Drogförebyggande arbete $i$ skolan: möjligheter och dilemman. Lund: Studentlitteratur

Proposition 2002/03:53 Stärkt skydd för barn i utsatta situationer $m$ m. Regeringen

Proposition 2009/10:105 Barn under 15 år som misstänks för brott. Regeringen.

Proposition 2014/15:25 Tydligare reaktioner på ungdomars brottslighet. Regeringen.

PROP 135 L 2010-2011 Endringer i straffeloven, straffeprocessloven, straffegenomforingsloven, konfliktrådsloven $m$. fl. (barn og straff). Justis- og beredskapsdepartementet.

Rikspolisstyrelsen (2008) Handlingsplan. Samverkan polis och kommun - för en lokalt förankrad polisverksambet $i$ hela landet. Stockholm: RPS. 
Rogers, Patricia (2011) Programteori som verktyg för utvärdering. I: Björn Blom; Stefan Morén \& Lennart Nygren, (red.) Utvärdering i socialt arbete. Utgångspunkter, modeller och användning. Stockholm: Natur \& Kultur Sahlin, Ingrid (2000) Brottsprevention som begrepp och sambällsfenomen. Lund: Arkiv förlag.

Sallnäs, Marie; Wiklund, Stefan \& Lagerlöf, Héléne (2010)

Samhällsvårdade barn, gate-keeping och forskning. Socialvetenskaplig tidskrift nr 2. s.116-133.

Sarnecki, Jerzy (2004) Kunskapsbaserad brottsprevention. Teoretiska utgångspunkter för brottsförebyggande arbete i Stockholms stad. Stockholms stad Scott, W. Richard (2008) Institutions and Organizations: ideas and interest. Thousand Oaks, California: Sage Silverman, David (2006) Interpreting qualitative data. London: Sage. Silverman, David (2005) Doing qualitative research. London: Sage. Skinner, Carrie (2010) Clients or offenders? The case for clarity of purpose in multi-agency working. I: Aaron Pycroft \& Dennis Gough (red.) Multi-agency working in criminal justice. Control and care in contemporary correctional practice. Bristol: The Policy press.

Skolverket (2009) Kraften av samverkan. Om samverkan kring barn och unga som far illa eller riskerar att fara illa. Stockholm: Fritzes

Sohlberg, Peter (2006) Teorier och kunskapsbildning i socialt arbete. I: Björn Blom; Stefan Morén \& Lennart Nygren Kunskap i socialt arbete. Om processer, villkor och användning. Stockholm: Natur \& Kultur.

Sohlberg, Peter \& Sohlberg Britt-Marie (2009) Kunskapens former. Vetenskapsteori och forskningsmetod. Malmö: Liber.

Socialstyrelsen (2005) Individ- och familjeomsorg - Lägesrapport 2004.

Stockholm.

Socialstyrelsen (2012) Kartläggning av samverkansinterventioner med syfte att motverka en kriminell livsstil bland unga. Stockholm: Socialstyrelsen Socialstyrelsen (2012) Samverkan i sociala insatsgrupper. Vägledning för lokalt arbete $i$ syfte att motverka en kriminell livsstil bland unga. Stockholm: Edita Västra aros AB. 
Socialstyrelsen, Rikspolisstyrelsen \& Myndigheten för skolutveckling (2007) Strategi för samverkan - kering barn och unga som far illa eller riskerar att fara illa. Västerås.

Statens offentliga utredningar 2008: 18 Evidensbaserad praktik $i$ socialtjänsten - till nytta för brukaren. Socialdepartementet.

Statens offentliga utredningar 2010:15 Kriminella grupperingar - motverka rekrytering och underlätta avhopp. Justitiedepartementet.

Statens offentliga utredningar 2012:34 Nya påföljder. Justitiedepartementet Stigsdotter Ekberg, Margareta (2010) Dom kallar oss värstingar. Om ungas lärande i mötet med skola, socialtjänst och polis (doktorsavhandling). Linneuniversitetet, Institutionen för pedagogic, psykologi och idrottsvetenskap. .

Storgaard, Anette (2004) Juvenile justice in Scandinavia. Journal of

Scandinavian studies in criminology and crime prevention Vol 5 (2), s.188-204.

Sundell, Knut \& Forster, Martin (2005). En grund för att växa. Forskning om att förebygga beteendeproblem hos barn (FoU-rapport 2005:1). Forsknings- och utvecklingsenheten, socialförvaltningen. Stockholms stad.

Svensson, Kerstin (2014) Varför fungerar det? Om betydelsen av förväntningar, institutioner och aktörer. I: Stig Linde \& Kerstin Svensson (red.) Förändringens entrepenörer och tröghetens agenter.

Människobehandlande organisationer ur ett nyinstutitionellt perspektiv. Stockholm: Liber

Svensson, Kerstin; Johnsson Eva \& Laanemets, Leili (2008)

Handlingsutrymme. Utmaningar i socialtjänsten. Stockholm: Natur \& Kultur.

Svensk Författningssamling, Lag (1990:52) med särskilda bestämmelser om vard av unga (LVU)

Svensk Författningssamling, (2001: 453 SoL) Socialtjänstlagen

Svensk Författningssamling, Lag (2003:460) om etikprövning av forskning som avser människor.

Svensk författningssamling, Lag (2012:804). om ändring i offentlighets- och sekretesslagen.

Söderberg, Christina (2009) Från risk till frisk. Socialarbetares föreställningar om vad som bidrar till en positiv utveckling hos utsatta ungdomar (magisteruppsats). Linköpings universitet, Institutionen för samhälls- och välfärdsstudier. 
Turner, Russel; Nilsson, Åsa \& Jidetoft, Nina (2015) SSPF - Ett fokus på ungdomar i riskzon. En implementeringsutvärdering av samverkan mellan skola, socialtjänst, polis och fritid för att motverka kriminalitet och missbruk. FoU i Väst/GR.

Turunen, Päivi (2004) Sambällsarbete $i$ Norden: diskurser och praktiker $i$ omvandling. Växjö: Växjö University Press

Wahlgren, Paula (2014) De laglydiga. Om skolans brottsförebyggande fostran (doktorsavhandling). Stockholms Universitet, Kriminologiska institutionen.

Vaismoradi, Mojtaba; Turunen, Hannele \& Bondas, Terese. (2013)

Content analysis and thematic analysis: Implications for conducting a quantitative descreptive study. Nursing and Health sciences 15, s. 398-405.

Watt Boolsen, Merete (2000) SSP-samarbejdet. Udvikling og perspektiver. Det kriminalpraeventive rad.

Vedung, Evert. (2009) Utvärdering i politik och förvaltning. Lund:

Studentlitteratur.

Weick, Karl E. (1995) Sensemaking in organizations. Thousand oaks

California: Sage

Weick, Karl E. \& Sutcliffe, Kathleen M. (2005) Organizing and the process of sensemaking. Organization science vol 16 (4), s.409-421.

Wibeck, Viktoria (2000) Fokusgrupper. Om fokuserade gruppintervjuer som undersökningsmetod. Lund: Studentlitteratur.

Wikström, Per-Olof H. \& Torstensson, Marie (1997) Lokalt brottsförebyggande arbete. Organisation och inriktning. Rapport från problemgruppen 1997:2. Solna: Polishögskolan.

Williams, Iestyn (2009) Offender health and social care: a review of the evidence on inter-agency collaboration. Health and social care in the community 17 (6), s. 573-580.

Willumsen, Elisabeth (2007). Interprofessionell samverkan och brukarmedverkan kring utsatta barn. I: Runo Axelsson \& Susanna Bihari Axelsson (red.) Folkhälsa I samverkan mellan professioner, organisationer och sambällssektorer. Polen: Studentlitteratur.

Vinnerljung, Bo (2011) Hjälp fosterbarn att klara sig bättre i skolan. I Anna Fredriksson och Anna Kakuli (red.) Ett annat hemma. Om sambällets ansvar för placerade barn, s 51-68. Stockholm: Gothia 
Wollter, Filip; Kassman, Anders \& Oscarsson, Lars (2012) Utvärdering av sociala insatsgrupper. Individinriktad samverkan kring unga i riskzonen. Ersta sköndal högskola.

\section{Websidor}

www.bra.se; Brottsförebyggande rådet

www.can.se; Centralförbundet för alkohol- och narkotikaupplysning

\section{Kommunala dokument}

\section{Lillestad}

(2011) Samverkansöverenskommelse Polismyndigheten i X län och Lillestads kommun

(2014) Handlingsplan. Bilaga till Samverkansöverenskommelse mellan Lillestads kommun och Polismyndigheten i X län.

(2013) Samverkan socialtjänst, skola polis och fritid - Handlingsplan

\section{Mellanstad}

(2013) Samverkansöverenskommelse mellan Polismyndigheten i Y län och Mellanstads kommun

(2013) Arbetsbok. Barn och unga 10-20 år i risk att utveckla eller som har ett kriminellt beteende och/eller missbruk

\section{Storstadsdel}

(2012) Samverkansöverenskommelse mellan Polismyndigheten i Z län och Stadsdelsförvalningen i Storstadsdel.

(2012) Handlingsplan för att minska ungdomars bruk av alkohol och narkotika och motverka deras kriminalitet 


\section{Bilagor}

\section{Bilaga 1: Metodbilaga}

Översikt empiriskt material och förfarande

Tid

moment

delmoment och förfarande

\begin{tabular}{|c|c|c|}
\hline Våren 2012 & $\begin{array}{l}\text { Planering och } \\
\text { genomförande av } \\
\text { inledande gruppintervjuer } \\
\text { samt observationer vid } \\
\text { SSPF-möten i Mellanstad }\end{array}$ & 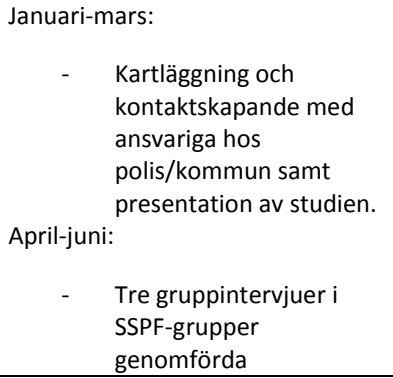 \\
\hline Hösten 2012 & Intervju & $\begin{array}{l}\text { Oktober: } \\
\begin{aligned} & \\
& \text { Gruppintervju med delar } \\
& \text { av SSPF-grupp i } \\
& \text { Storstadsdel }\end{aligned}\end{array}$ \\
\hline Våren 2013 & $\begin{array}{l}\text { Intervjuer och } \\
\text { observationer }\end{array}$ & $\begin{array}{cl}\text { Januari-maj } \\
-\quad \\
\quad \text { Individuell intervju med } \\
\text { - } \quad \text { Obamordnare Mellanstad, } \\
\\
\text { styrgruppsmöte och ett } \\
\text { arbetsgruppsmöte }\end{array}$ \\
\hline Hösten 2013 & $\begin{array}{l}\text { Intervjuer och } \\
\text { observationer }\end{array}$ & 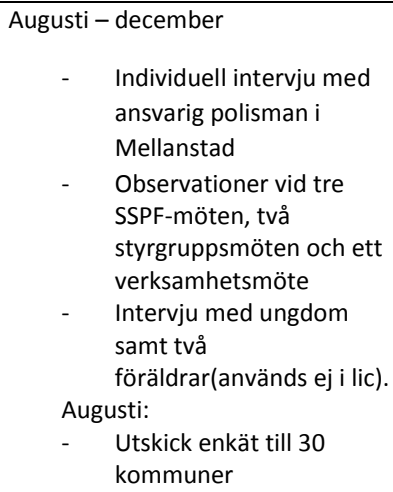 \\
\hline
\end{tabular}




\begin{tabular}{|c|c|c|}
\hline Våren 2014 & $\begin{array}{l}\text { Intervjuer och } \\
\text { observationer }\end{array}$ & $\begin{array}{l}\text { Februari- juni: } \\
\begin{aligned} & \text { - } \text { Första gruppintervju med } \\
& \text { SSPF-gruppen i Lillestad } \\
& \text { - } \text { Observation vid ett } \\
& \text { stygruppsmöte och ett } \\
& \text { arbetsgruppsmöte } \\
&-\quad \text { Gruppintervju } 2 \text { med } \\
& \text { SSPF-gruppen i Lillestad } \\
& \text { - } \text { Analys av vägledande och } \\
& \text { styrande dokument för } \\
& \text { SSPF (kap 6) } \\
& \text { - } \text { Intervju med två } \\
& \text { ungdomar och två } \\
& \text { föräldrar (används ej i lic) }\end{aligned} \\
\end{array}$ \\
\hline \multirow[t]{2}{*}{ Hösten 2014} & Gruppintervju Mellanstad & $\begin{array}{ll}\text { Augusti: } & \\
& \\
\text { - } & \text { Gruppintervju } \\
& \text { chefsgrupp Mellanstad } \\
-\quad & \text { Gruppintervju med SSPF- } \\
& \text { ansvarig polis och } \\
& \text { samordnare i Storstad. } \\
-\quad & \text { Individuell intervju med } \\
& \text { polisman Storstadsdel } \\
\end{array}$ \\
\hline & Intervju & $\begin{array}{l}\text { Maj: } \\
\begin{array}{ll} & \\
-\quad & \text { Avslutande intervju med } \\
& \text { SSPF-gruppen i Lillestad }\end{array} \\
\end{array}$ \\
\hline
\end{tabular}




\section{Bilaga 2: Enkät till SSPF-koordinatorer}

Enkät om den individriktade SSP(F)-verksamheten i din kommun/stadsdel

Resultaten från denna enkät kommer att ingå som en del i en pågående studie om SSP(F). Era svar kommer att avidentifieras i resultatredovisningen. Sista frågan handlar om hjälp att få fram ungdomar/familjer till intervjustudien. Om du svarar positivt på denna kan du välja mellan att skriva dina kontaktuppgifter eller kontakta mig (Christina Söderberg). Enkäten är enkel och bör bara ta några minuter av din tid. Tack på förhand!

Om ni inte arbetar individinriktat med modellen så svara gärna på fråga 1 och 2 ändå.

\section{Hur länge har SSP(F) funnits i din kommun/stadsdel?}

- mindre än 1 år

口 1-2 år

口 3-5 år

$\square$ mer än 5 år

$\square$ Vi har inte längre SSPF

Beskriv kort målgruppen för individuell SSP(F) - ålder, typ och grad av problematik (dvs är det en relativt tidig insats eller för en mer avancerad målgrupp eller både och?) 
Arbetar din kommun/stadsdel med:

- SSP på individnivå

- SSP på gruppnivå/områdesnivå

- SSPF på individnivå

ㄴ SSPF på gruppnivå/områdesnivå

ev kommentar

Hur ser könsfördelningen ut bland de ungdomar som varit aktuella för SSP(F)?

口 Övervägande pojkar

口 Övervägande flickor

ㄴ Ungefär lika fördelning pojkar/flickor

ev kommentar

Vilka är de främsta framgångsfaktorerna (en eller flera)

för SSPF?

口 Utbyte av information

口 Delaktighet från föräldrar

口 Tveksam

口 Annat, nämligen 
Vad skulle du säga främst skiljer SSP(F) mot det mer traditionella sättet att arbeta med målgruppen?

Beskriv i fritext eventuella svårigheter i SSP(F)-arbetet, hinder eller försvårande faktorer.

Vilka är de vanligaste insatserna/interventionerna/aktiviteterna som SSPF leder till för den unge? Fler val möjliga.

G Förändring i skolsituationen

口 Föräldrastöd

口 Insatser på fritiden

口 Interventioner från socialtjänsten i familjen

$\square \quad$ Inga större förändringar men bättre samsyn

$\square \quad$ Placering

- Interventioner från socialtjänsten till den unge

Annat, nämligen 


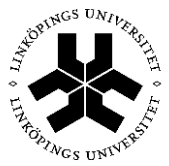

\section{Linköpings universitet}

\section{SSPF-modellen för brottspreventiv samverkan- interprofessionellt perspektiv}

Jag är doktorand i socialt arbete, vid Linköpings universitet, som planerar ett forskningsprojekt kring brottspreventiv samverkan ur olika perspektiv som de professionellas perspektiv och brukarens perspektiv. För att fånga professionens perspektiv på detta, har jag valt att utifrån exemplet SSPF göra gruppintervjuer med samverkansgrupperna i SSPF.

Ett syfte med studien är att beskriva dagens brottspreventiva samverkan runt unga som riskerar en negativ utveckling. Detta genom att fånga upp frågor kring de olika samverkansparternas roller vid samverkan, etiska dilemman, upplevda möjligheter såväl som svårigheter med SSPF som modell. Ett annat syfte är att undersöka och problematisera hur brukarperspektivet/ brukarens perspektiv blir synligt i samverkan och hur man i samverkansgrupper ser på detta. Dessa är områden som är angelägna att få ny eller fördjupad kunskap omkring. För att fånga det interprofessionella perspektivet och för att få en så bred bild som möjligt är det viktigt att olika samverkansparter kommer till tals.

Metoden som kommer att användas är gruppintervjuer i form av fokusgrupper, där SSPF-gruppen diskuterar runt teman som forskaren presenterar samt i vissa fall individuella intervjuer. Detta spelas in på band och utskrifter görs av det som sagts.

Bandinspelningar och utskrifter kommer att behandlas konfidentiellt. 
Utöver intervjuerna kommer även observationsanteckningar att föras vid några SSPF-möten. Vid dessa tillfällen kommer muntlig information om detta att ges före mötets början.

För att säkerställa enskilda personers skydd mot otillbörlig insyn och kravet på vetenskaplig relevans krävs ett informerat samtycke mellan deltagande forskare och berörda personer.

Christina Söderberg

Doktorand i socialt arbete

christina.soderberg@liu.se
Martin Börjeson

Ansvarig handledare

Docent i socialt arbete

martin.borjeson@liu.se

\section{Undertecknad ger sitt samtycke till att delta i ovan nämnda studie och är informerad om:}

- Studiens syfte och uppläggning

- Att deltagandet är frivilligt och när som helst kan avbrytas

- Att uppgifter som lämnas är konfidentiella och inte kommer att användas i annat syfte än forskning

- Att resultatet av forskningen kommer att presenteras på ett sådant sätt att deltagarna inte är identifierbara

Undertecknad deltagare

Norrköping 201 - 
Bilaga 4: Frågeområden vid individuella intervjuer SSPF -professionella

- Berätta om hur verksamheten kom till/ lite historik

- Hur ser målgruppen för insatsen ut?

- Berätta om ett ärendes gång, från start till mål

- Vad skulle du beskriva är skillnaden för den enskilde mot ett traditionellt sätt att arbeta?

- Vilka är vinsterna med att arbeta på detta sätt?

- Vilka är svårigheterna?

- Övrigt 
Bilaga 4: Frågeområden för gruppintervjuer SSPF

- SSPF-modellen - på vilket sätt har den förändrat arbetet?

- Hur ser gången och ansvarsfördelningen ut vid ett ärende?

- Hur ser ni på samtycke till informationsutbyte - vad betyder det- för er- för familjen- den unge?

- Hur ser samarbetet med familjen ut? Delaktighet?

- Förväntningar/förhoppningar/farhågor gällande SSPF 
